\title{
Chapter 10 \\ Microplastics in the Marine Environment: Distribution, Interactions and Effects
}

\author{
Amy Lusher
}

\begin{abstract}
Microplastics are an emerging marine pollutant. It is important to understand their distribution in the marine environment and their implications on marine habitats and marine biota. Microplastics have been found in almost every marine habitat around the world, with plastic composition and environmental conditions significantly affecting their distribution. Marine biota interact with microplastics including birds, fish, turtles, mammals and invertebrates. The biological repercussions depend on to the size of microplastics encountered, with smaller sizes having greater effects on organisms at the cellular level. In the micrometre range plastics are readily ingested and egested, whereas nanometre-sized plastics can pass through cell membranes. Despite concerns raised by ingestion, the effects of microplastic ingestion in natural populations and the implications for food webs are not understood. Without knowledge of retention and egestion rates of field populations, it is difficult to deduce ecological consequences. There is evidence to suggest that microplastics enter food chains and there is trophic transfer between predators and prey. What is clear is that further research on a variety of marine organisms is required to understand the environmental implications of microplastics in more detail and to establish effects in natural populations.
\end{abstract}

Keywords Distribution - Ingestion - Trophic transfer - Habitat alterations • Biomagnification $\cdot$ Bioaccumulation

\footnotetext{
A. Lusher $(\bowtie)$

Marine and Freshwater Research Centre, Galway-Mayo Institute of Technology,

Dublin Road, Galway, Ireland

e-mail: amy.lusher@ research.gmit.ie
} 


\subsection{Introduction}

With the increasing reliance on plastics as an everyday item, and rapid increase in their production and subsequent disposal, the environmental implications of plastics are a growing concern. The benefits of plastics, including their durability and resistance to degradation, inversely result in negative environmental impacts. As user-plastics are primarily "single use" items they are generally disposed of within one year of production, and whilst some plastic waste is recycled, the majority ends up in land-fill. Concerns arise when plastics enter the marine environment through indiscriminate disposal and it has been estimated that up to $10 \%$ of plastic debris produced will enter the sea (Thompson 2006). Interactions between litter and the marine environment are complex. The impacts of larger plastic debris are discussed by Kühn et al. (2015) and consequences include aesthetic, social and economic issues (Newman et al. 2015), and numerous environmental impacts on marine biota (Derraik 2002; Barnes et al. 2009). However, with an ever increasing reliance on plastic products, and as plastic production, use and disposal continue, microplastics are of increasing concern (Sutherland et al. 2010). Microplastics enter the sea from a variety of sources (Browne 2015) and distributed by oceans currents; these ubiquitous contaminants are widespread (Cózar et al. 2014). The amount of microplastics in the sea will continue to rise, leading to gradual but significant accumulation in coastal and marine environments (Andrady and Neal 2009).

Increasing evidence of microplastics in the sea has led to a need to understand its environmental impacts as a form of marine pollution. A recent review of marine debris research found only $10 \%$ of publications to focus on microplastics, the majority of which were from the last decade (CBD 2012). Even though plastic is the primary constituent of marine debris, microplastics are considered under-researched due to difficulties in assessing their distribution and abundance (Doyle et al. 2011). It has only been in recent years that international, national and regional efforts were made to quantify microplastics in the sea. The Marine Strategy Framework Directive (MSFD, 2008/56/EC) has highlighted concerns for environmental implications of marine litter and one of the key attributes of the MSFD is to determine the ecological harm caused by microplastics and their associated chemicals (Zarfl et al. 2011).

Microplastics were first described as microscopic particles in the region of $20 \mu \mathrm{m}$ diameter (Thompson et al. 2004). For the purpose of this study, microplastic refers to items $<5 \mathrm{~mm}$ in size using the criteria developed by US National Oceanic and Atmospheric Administration (NOAA) (Arthur et al. 2009). The small size of microplastics makes them available for interaction with marine biota in different trophic levels. By inhabiting different marine habitats, a range of organisms are vulnerable to exposure (Wright et al. 2013a). At the millimetre and micrometre scale, sorption of microplastics is dominated by bulk portioning, with effects including blockages when fibres or fragments form aggregates. 
Whereas at smaller size ranges, specifically the nanometre scale, there is a potential for microplastics to cause harm to organisms (Galloway 2015; Koelmans et al. 2015). Additionally, the consequences of exposure to chemicals associated with plastics are being investigated (Rochman 2015). A widely cited hypothesis explores how the large surface area to volume ratio of microplastics leaves them prone to adsorbing waterborne organic pollutants and the potential for toxic plasticisers to leach from polymer matrices into organisms tissues (Teuten et al. 2007). It was further hypothesized that if subsequently ingested, microplastics may act as a route for toxin introduction to the food chain (Teuten et al. 2009). Whether microplastics act as vectors depends on the gradient between microplastics and biota lipids (Koelmans 2015).

It is important to understand the transport and distribution of microplastics before understanding their fate, including the physical and chemical effects they could have on marine organisms. The objectives of this chapter are to assess the environmental impact of microplastic in the sea by: (1) summarising the distribution of marine microplastics, including the use of models to understand the distribution; (2) determine the interaction of microplastics with marine organisms.

\subsection{The Global Distribution of Microplastics in the Sea}

From strandlines on beaches to the deep seafloor and throughout the water column, microplastic research is dominated by studies monitoring microplastic distribution and abundance in the marine environment (Ivar du Sol and Costa 2014). A recent estimate suggested there could be between 7000 and 35,000 tons of plastic floating in the open ocean (Cózar et al. 2014). Another study estimated that more than five trillion pieces of plastic and $>250,000 \mathrm{t}$ are currently floating in the oceans (Eriksen et al. 2014). Once in the sea microplastics are transported around the globe by ocean currents where they persist and accumulate. Microplastics are suspended in the water column (e.g. Lattin et al. 2004), surface waters (e.g. Cózar et al. 2014), coastal waters (e.g. Ng and Obbard 2006), estuaries (e.g. Browne et al. 2010), rivers (Sadri and Thompson 2014), beaches (e.g. Browne et al. 2011) and deep-sea sediments (Van Cauwenberghe et al. 2013b; Woodall et al. 2014; Fischer et al. 2015). Suspended in the water column, microplastics can become trapped by ocean currents and accumulate in central ocean regions (e.g. Law et al. 2010). Ocean gyres and convergent zones are noteworthy areas of debris accumulation, as the rotational pattern of currents cause high concentrations of plastics to be captured and moved towards the centre of the region (Karl 1999). As gyres are present in all of the world's oceans, microplastic accumulation can occur at a global scale and has been documented during the past four decades. Distribution is further influenced by wind mixing, affecting the vertical movement of plastics 
(Kukulka et al. 2012). Physical characteristics of plastic polymers, including their density, can influence their distribution in the water column and benthic habitats (Murray and Cowie 2011). Buoyant plastics float at the surface, whereas more dense microplastics or those fouled by biota sink to the sea floor. It has recently been estimated that $50 \%$ of the plastics from municipal waste have a higher density than seawater such that it will readily sink to the seafloor (Engler 2012). It is currently not economically feasible nor is it desirable to remove microplastics from the ocean.

A number of concerns have been raised regarding the assessment of microplastic distribution. There are multiple pathways for the introduction of microplastics into the marine environment which do not have accurate timescales for the rate of degradation (Ryan et al. 2009). Quantification is complicated by the size of the oceans in relation to the size of plastics being assessed (Cole et al. 2011), which are further confounded by ocean currents and seasonal patterns introducing spatial and temporal variability (Doyle et al. 2011). As a result, there are various techniques applied to the sampling of microplastics in the marine environment (Löder and Gerdts 2015). Results of studies have been reported in different dimensions, e.g. the number of microplastics in a known water volume (particles $\mathrm{m}^{-3}$ ) or area measurements (particles $\mathrm{km}^{-2}$ ). This discrepancy presents a problem when comparing between studies, as it is not possible to compare results directly. For the purpose of this review, which aims to carry out a critical assessment of the global knowledge of microplastic distribution, a conversion was made to enable comparisons between the different dimensions of measurement. It is reasonable to assume that surface samples are collected in the top $0.20 \mathrm{~m}$ of water and therefore by making a simple calculation to add a third dimension (firstly converting particle $\mathrm{km}^{-2}$ to $\mathrm{m}^{-2}$, then multiplying by $0.20 \mathrm{~m}$ to convert to a volume measurement, $\mathrm{m}^{-3}$ ) we are able to compare different sampling methods in a variety of geographical locations. However, because of current directions in relation to boats, and approximate vessel speeds, it is difficult to calculate the amount of water passing through a net. As nets can ride out of the water, the exact volume of water passing through is unknown: the calculations have to be considered, at best, estimations.

It is important to understand the distribution of microplastics in the sea to grasp their potential impacts. This section will present a number of studies documenting microplastics in geographical regions including the Pacific, Atlantic, European Seas and the Mediterranean Sea, Indian Ocean and polar regions. It will introduce modelling strategies that have been utilised to understand microplastic distribution and accumulation around the globe.

\subsubsection{Microplastics in the Pacific Ocean}

Numerous studies on microplastics have been undertaken in the Pacific Ocean, the world's largest water basin (Table 10.1). One area which has received considerable attention is the North Pacific Central Gyre (NPCG) located off the west coast of 
10 Microplastics in the Marine Environment ...

Table 10.1 Mean abundance ( \pm SD, unless stated otherwise) of microplastic debris in the surface waters of the Pacific Ocean

\begin{tabular}{|c|c|c|c|c|}
\hline Location & Equipment used & Amount $( \pm \mathrm{SD})$ & $\begin{array}{l}\text { Particles } \\
\left(\mathrm{m}^{-3}\right)\end{array}$ & Source \\
\hline \multicolumn{5}{|l|}{ North Pacific } \\
\hline Bering Sea & Ring net & a $80( \pm 190) \mathrm{km}^{-2}$ & 0.000016 & $\begin{array}{l}\text { Day and Shaw } \\
\text { (1987) }\end{array}$ \\
\hline Bering Sea & Ring/neuston net & $1.0( \pm 4.2) \mathrm{km}^{-2}$ & 0.0000002 & Day et al. (1990) \\
\hline Bering Sea & $\begin{array}{l}\text { Sameota sampler/ } \\
\text { manta net }\end{array}$ & $\begin{array}{l}\text { Range: } \\
0.004-0.19 \mathrm{~m}^{-3}\end{array}$ & $0.004-0.19$ & Doyle et al. (2011) \\
\hline Subarctic N.P. & Ring net & $\mathrm{a} 3,370( \pm 2,380) \mathrm{km}^{-2}$ & 0.00067 & $\begin{array}{l}\text { Day and } \\
\text { Shaw (1987) }\end{array}$ \\
\hline Subarctic N.P. & Ring/neuston net & $61.4( \pm 225.5) \mathrm{km}^{-2}$ & 0.000012 & Day et al. (1990) \\
\hline \multicolumn{5}{|c|}{ Eastern North Pacific } \\
\hline $\begin{array}{l}\text { Vancouver Island, } \\
\text { Canada }\end{array}$ & $\begin{array}{l}\text { Underway } \\
\text { sampling }\end{array}$ & $279( \pm 178) \mathrm{m}^{-3}$ & 279 & $\begin{array}{l}\text { Desforges et al. } \\
\text { (2014) }\end{array}$ \\
\hline $\begin{array}{l}\text { Eastern North } \\
\text { Pacific }\end{array}$ & Plankton net & $\begin{array}{l}\text { Estimated 21,290 t } \\
\text { afloat }\end{array}$ & I & Law et al. (2014) \\
\hline $\begin{array}{l}\text { N.P. transitional } \\
\text { water }\end{array}$ & $\begin{array}{l}\text { Ring/neuston } \\
\text { net }\end{array}$ & $291.6( \pm 714.4) \mathrm{km}^{-2}$ & 0.00012 & Day et al. (1990) \\
\hline N.P. central gyre & Manta net & $334,271 \mathrm{~km}^{-2}$ & ${ }^{*} 2.23$ & Moore et al. (2001) \\
\hline N.P. central gyre & Manta net & $85,184 \mathrm{~km}^{-2}$ & 0.017 & Carson et al. (2013) \\
\hline $\begin{array}{l}\text { N.P. subtropical } \\
\text { gyre 1999-2010 }\end{array}$ & $\begin{array}{l}\text { Plankton net/manta } \\
\text { net/neuston net }\end{array}$ & Median: $0.116 \mathrm{~m}^{-3}$ & 0.12 & $\begin{array}{l}\text { Goldstein et al. } \\
\text { (2012) }\end{array}$ \\
\hline $\begin{array}{l}\text { South Californian } \\
\text { current system }\end{array}$ & Manta net & $\begin{array}{l}\text { Median: } \\
0.011-0.033 \mathrm{~m}^{-3}\end{array}$ & $\begin{array}{l}0.011- \\
0.033\end{array}$ & $\begin{array}{l}\text { Gilfillan et al. } \\
\text { (2009) }\end{array}$ \\
\hline $\begin{array}{l}\text { Santa Monica Bay, } \\
\text { California, USA }\end{array}$ & Manta net & $3.92 \mathrm{~m}^{-3}$ & 3.92 & Lattin et al. (2004) \\
\hline $\begin{array}{l}\text { Santa Monica Bay, } \\
\text { California, USA }\end{array}$ & Manta net & $7.25 \mathrm{~m}^{-3}$ & 7.25 & Moore et al. (2002) \\
\hline $\begin{array}{l}\text { N.P. subtropical } \\
\text { gyre }\end{array}$ & Manta net & $\begin{array}{l}\text { Median: } \\
0.02-0.45 \mathrm{~m}^{-2}\end{array}$ & $\begin{array}{l}0.0042- \\
0.089\end{array}$ & $\begin{array}{l}\text { Goldstein et al. } \\
\text { (2013) }\end{array}$ \\
\hline $\begin{array}{l}\text { South Equatorial } \\
\text { current }\end{array}$ & \multirow[t]{2}{*}{ Neuston net } & $137 \mathrm{~km}^{-2}$ & 0.000027 & \multirow[t]{2}{*}{ Spear et al. (1995) } \\
\hline $\begin{array}{l}\text { Equatorial counter } \\
\text { current }\end{array}$ & & $24 \mathrm{~km}^{-2}$ & 0.0000048 & \\
\hline \multicolumn{5}{|c|}{ Western North Pacific } \\
\hline Subtropical N.P. & Ring net & $\begin{array}{l}\text { a96,100 } \\
( \pm 780,000) \mathrm{km}^{-2}\end{array}$ & 0.019 & $\begin{array}{l}\text { Day and Shaw } \\
\text { (1987) }\end{array}$ \\
\hline Subtropical N.P. & $\begin{array}{l}\text { Ring/neuston } \\
\text { net }\end{array}$ & $535.1( \pm 726.1) \mathrm{km}^{-2}$ & 0.00011 & Day et al. (1990) \\
\hline $\begin{array}{l}\text { Near-shore waters, } \\
\text { Japan }\end{array}$ & Ring/neuston net & $128.2( \pm 172.2) \mathrm{km}^{-2}$ & 0.000026 & Day et al. (1990) \\
\hline $\begin{array}{l}\text { Kuroshio current } \\
\text { system }\end{array}$ & Neuston net & $\begin{array}{l}174,000 \\
( \pm 467,000) \mathrm{km}^{-2}\end{array}$ & 0.034 & $\begin{array}{l}\text { Yamashita and } \\
\text { Tanimura (2007) }\end{array}$ \\
\hline
\end{tabular}


Table 10.1 (continued)

\begin{tabular}{|c|c|c|c|c|}
\hline Location & Equipment used & Amount $( \pm \mathrm{SD})$ & $\begin{array}{l}\text { Particles } \\
\left(\mathrm{m}^{-3}\right)\end{array}$ & Source \\
\hline $\begin{array}{l}\text { Yangtze estuary } \\
\text { system, East } \\
\text { China Sea }\end{array}$ & Neuston net & $\begin{array}{l}4,137.3 \\
\left( \pm 8.2 \times 10^{4}\right) \mathrm{m}^{-3}\end{array}$ & 4137.3 & Zhao et al. (2014) \\
\hline $\begin{array}{l}\text { Geoje Island, } \\
\text { South Korea }\end{array}$ & $\begin{array}{l}\text { Bulk sampling, } \\
\text { hand-net, manta } \\
\text { net }\end{array}$ & $\begin{array}{l}16,000 \\
\left( \pm 14 \times 10^{3}\right) \mathrm{m}^{-3}\end{array}$ & 16,000 & Song et al. (2014) \\
\hline \multicolumn{5}{|l|}{ South Pacific } \\
\hline $\begin{array}{l}\text { South Pacific } \\
\text { subtropical gyre }\end{array}$ & Manta net & $\begin{array}{l}26,898 \\
( \pm 60,818) \mathrm{km}^{-2}\end{array}$ & 0.0054 & $\begin{array}{l}\text { Eriksen et al. } \\
(2013)\end{array}$ \\
\hline \multirow[t]{2}{*}{ Australian coast } & Neston net & \multirow{2}{*}{$\begin{array}{l}\mathrm{b}_{4,256.3} \\
( \pm 757.8) \mathrm{km}^{-2}\end{array}$} & \multirow[t]{2}{*}{0.00085} & \multirow[t]{2}{*}{ Reisser et al. (2013) } \\
\hline & Manta net & & & \\
\hline
\end{tabular}

If particles in $\mathrm{m}^{-3}$ were not reported, the values have been converted as follows: (1) $\mathrm{km}^{-2}$ to $\mathrm{m}^{-2}$ : by division by $1,000,000$ followed by multiplication by $0.2 \mathrm{~m} ;(2) \mathrm{m}^{-2}$ to $\mathrm{m}^{-3}$ carried out by 0.2 multiplication

${ }^{a}$ Mean $\pm 95 \%$ confidence intervals

${ }^{b}$ Mean \pm standard error

California, USA. The gyre contains possibly the most well publicised area of plastic accumulation, known as the "Great Pacific Garbage Patch" (Kaiser 2010). Microplastic concentrations in the NPCG have increased by two orders of magnitude in the last four decades (Goldstein et al. 2012). In comparison, microplastic abundance in the North Pacific subtropical gyre (NPSG) is widespread and spatially variable, but values are two orders of magnitude lower than in the NPCG (Goldstein et al. 2013). Microplastic studies in the south Pacific are limited to the subtropical gyre where an increasing trend of microplastics was found towards the centre of the gyre (5.38 particles $\mathrm{m}^{-3}{ }^{1}$ Eriksen et al. 2013). In a similar way to macroplastic debris, oceanographic features strongly affect the distribution of microplastics in open oceans and areas of upwelling create oceanographic convergence zones for marine debris.

Coastal ecosystems of the Pacific appear to be impacted by microplastics in areas of nutrient upwelling (Doyle et al. 2011) and influenced by local weather systems (Moore et al. 2002; Lattin et al. 2004). Microplastic load increased further inshore, reflecting the inputs from terrestrial runoff and particles re-suspended from sediments following storms (Lattin et al. 2004). Microplastics are in turn transported by ocean currents from populated coastal areas (Reisser et al. 2013). This is also reflected in offshore subsurface waters which had 4-27 times less plastics than coastal sites in the northeast Pacific (Desforges et al. 2014).

Pre-production plastic resin pellets and fragments wash up on coastlines worldwide and have been recovered from several Pacific beaches (Table 10.2). Plastic pellets, typically $3-5 \mathrm{~mm}$ in size, are made predominantly from the polymers polyethylene and polypropylene (Endo et al. 2005; Ogata et al. 2009). The average

${ }^{1}$ Calculated from $\mathrm{km}^{-2}$. 
10 Microplastics in the Marine Environment ...

Table 10.2 Mean microplastic abundance ( \pm SD, unless otherwise stated) in sediments from the Pacific

\begin{tabular}{|c|c|c|c|}
\hline Location & Types & Amount $( \pm \mathrm{SD})$ & Source \\
\hline \multicolumn{4}{|l|}{ North Pacific } \\
\hline Pacific beaches & Fragments $10 \mathrm{~mm}$ & 1 & Hirai et al. (2011) \\
\hline \multirow{2}{*}{$\begin{array}{l}9 \text { beaches, Hawaiian } \\
\text { islands }\end{array}$} & Fragments $1-15 \mathrm{~mm}$ & a $37.8 \mathrm{~kg}^{-1}$ & \multirow{2}{*}{$\begin{array}{l}\text { aMcDermid and } \\
\text { McMullen (2004) }\end{array}$} \\
\hline & Pellets $1-15 \mathrm{~mm}$ & $\mathrm{a} 4.9 \mathrm{~kg}^{-1}$ & \\
\hline Hawaiian islands & Pellets and fragments & I & Rios et al. (2007) \\
\hline $\begin{array}{l}\text { Kauai, Hawaiian } \\
\text { islands }\end{array}$ & $\begin{array}{l}\text { Fragments and pellets } \\
0.8-6.5 \mathrm{~mm}\end{array}$ & 1 & Corcoran et al. (2009) \\
\hline $\begin{array}{l}\text { Kauai, Hawaiian } \\
\text { islands }\end{array}$ & Fragments $<1 \mathrm{~cm}$ & 1 & $\begin{array}{l}\text { Cooper and Corcoran } \\
\text { (2010) }\end{array}$ \\
\hline $\begin{array}{l}\text { Kamillo Beach, } \\
\text { Hawaii }\end{array}$ & Pellets and fragments & Total: 248 & Carson et al. (2011) \\
\hline \multicolumn{4}{|l|}{ Northeast Pacific } \\
\hline $\begin{array}{l}\text { Los Angeles, } \\
\text { California, USA }\end{array}$ & Pellets and fragments & 1 & Rios et al. (2007) \\
\hline $\begin{array}{l}\text { San Diego, California, } \\
\text { USA }\end{array}$ & $\begin{array}{l}\text { Pellets and fragments } \\
<5 \mathrm{~mm}\end{array}$ & 1 & Van et al. (2012) \\
\hline Beaches, western USA & Pellets & I & Ogata et al. (2009) \\
\hline $\begin{array}{l}\text { Guadalupe Island, } \\
\text { Mexico }\end{array}$ & Pellets and fragments & I & Rios et al. (2007) \\
\hline \multicolumn{4}{|l|}{ Northwest Pacific } \\
\hline $\begin{array}{l}\text { Coastal beaches, } \\
\text { Russia }\end{array}$ & Fragments and pellets & $\mathrm{b}_{29} \mathrm{~m}^{-2}$ & Kusui and Noda (2003) \\
\hline Tokyo, Japan & Pellets & $>1,000 \mathrm{~m}^{-2}$ & Kuriyama et al. (2002) \\
\hline Coastal beaches, Japan & Pellets & I & Mato et al. (2001) \\
\hline \multirow[t]{2}{*}{ Coastal beaches, Japan } & Pellets & ${ }^{b} 0.52 \mathrm{~m}^{-2}$ & \multirow[t]{2}{*}{ Kusui and Noda (2003) } \\
\hline & Fragments & ${ }^{b} 1.1 \mathrm{~m}^{-2}$ & \\
\hline Coastal beaches, Japan & Pellets $<5 \mathrm{~mm}$ & $>100$ per beach & Endo et al. (2005) \\
\hline \multicolumn{4}{|l|}{ Korean Strait } \\
\hline \multirow{3}{*}{$\begin{array}{l}\text { Heugnam Beach, South } \\
\text { Korea }\end{array}$} & PS spheres & $874( \pm 377) \mathrm{m}^{-2}$ & \multirow[t]{3}{*}{ Heo et al. (2013) } \\
\hline & Fragments & $25( \pm 10) \mathrm{m}^{-2}$ & \\
\hline & Pellets & $41( \pm 19) \mathrm{m}^{-2}$ & \\
\hline \multicolumn{4}{|l|}{ South China Sea } \\
\hline $\begin{array}{l}\text { Ming Chau Island, } \\
\text { Vietnam }\end{array}$ & Pellets & 1 & Ogata et al. (2009) \\
\hline Hong Kong, China & Pellets & 1 & Ogata et al. (2009) \\
\hline \multicolumn{4}{|l|}{ South Pacific } \\
\hline $\begin{array}{l}\text { Coastal beaches, New } \\
\text { Zealand }\end{array}$ & Pellets $<5 \mathrm{~mm}$ & $>1,000 \mathrm{~m}^{-1}$ & Gregory (1978) \\
\hline Coastal beaches, Chile & $\begin{array}{l}\text { Fragments and pellets } \\
1-10 \mathrm{~mm}\end{array}$ & $30 \mathrm{~m}^{-2}$ & $\begin{array}{l}\text { Hidalgo-Riz and Thiel } \\
\text { (2013) }\end{array}$ \\
\hline Easter Island, Chile & $\begin{array}{l}\text { Fragments and pellets } \\
1-10 \mathrm{~mm}\end{array}$ & $805 \mathrm{~m}^{-2}$ & $\begin{array}{l}\text { Hidalgo-Riz and Thiel } \\
\text { (2013) }\end{array}$ \\
\hline
\end{tabular}

${ }^{\mathrm{a} C a l c u l a t e d}$ from total plastic collected from an overall total of $440 \mathrm{~L}$ of beach sediment

${ }^{\mathrm{b}}$ Calculated from total plastics found over total survey area 
abundance of plastic fragments on beaches in the southeast Pacific was greater in isolated areas (Easter Island: $>800$ items $\mathrm{m}^{-2}$ ) than on beaches from continental Chile (30 items $\mathrm{m}^{-2}$ ) (Hidalgo-Ruz and Thiel 2013). This trend has been seen in the Hawaiian archipelago, where the remotest beaches on Midway Atoll and Moloka'I contained the highest quantity of plastic particles (McDermid and McMullen 2004; Corcoran et al. 2009; Cooper and Corcoran 2010).

\subsubsection{Microplastics in the Atlantic Ocean}

Research on microplastic distribution in the Atlantic is less extensive than in the Pacific (Table 10.3), but includes a number of long-term studies. A time-series conducted in the north Atlantic and Caribbean Sea identified microplastics in $62 \%$ of the trawls conducted with densities reaching 580,000 particles $\mathrm{km}^{-2}$ (Law et al. 2010). Distinct patterns emerged with the highest concentration (83\% of plastics) in subtropical latitudes, $22^{\circ} \mathrm{N}$ and $88^{\circ} \mathrm{N}$, of the north Atlantic gyre marking the presence of a large-scale convergence zone (Law et al. 2010; Morét-Ferguson et al. 2010) similar to the south Pacific (Eriksen et al. 2013). Converging surface currents driven by winds are assumed to be the driving force of this accumulation. To assess long-term trends in abundance, a time-series data set of continuous plankton recorder (CPR) samples from north Atlantic shipping routes were re-examined and microplastics were identified from the 1960s with a significant increase over time (Thompson et al. 2004). Regular sampling schemes have begun to monitor the spatial and temporal trends of microplastics in the northeast Atlantic and found microplastics to be widespread and abundant (Lusher et al. 2014).

Microplastics accumulate in the coastal pelagic zones of the Atlantic (Table 10.3). Water samples from the Portuguese coast identified microplastics in $61 \%$ of the samples with higher concentrations found in Costa Vicentina and Lisbon (0.036 and 0.033 particles $\mathrm{m}^{-3}$, respectively) than in the Algarve and Aveiro (0.014 and 0.002 particles $\mathrm{m}^{-3}$, respectively). These results are probably related to the proximity to urban areas and river runoff (Frias et al. 2014), which is similar to the trend seen in the Pacific. Following a MARMAP cruise in the south Atlantic, microplastic beads were present in 14.6-34.2\% of tows conducted (van Dolah et al. 1980). Pelagic subsurface plankton samples from a geographically isolated archipelago, Saint Peter and Saint Paul, were not free of microplastic fragments. Modelling studies suggested that oceanographic mechanisms promote the topographic trapping of zooplankton and therefore microplastics might be retained by small-scale circulation patterns (Ivar do Sul et al. 2013). Additionally, research in the Firth of Clyde (U.K.) indicated that intense environmental sampling regimes are necessary to encompass the small-scale and temporal variation in coastal microplastic abundance (Welden, pers. comm.).

Microplastic granules and pellets have been identified on Atlantic beaches since the 1980s (Table 10.4). It was hypothesised that pre-production pellets are 
10 Microplastics in the Marine Environment ...

Table 10.3 Mean abundance ( \pm SD, unless stated otherwise) of microplastic debris in the surface waters of the Atlantic Ocean

\begin{tabular}{|c|c|c|c|c|}
\hline Location & Equipment used & Amount $( \pm$ SD) & Particles $\left(\mathrm{m}^{-3}\right)$ & Source \\
\hline \multicolumn{5}{|l|}{ North Atlantic } \\
\hline $\begin{array}{l}\text { North Atlantic } \\
\text { gyre }\left(29-31^{\circ} \mathrm{N}\right)\end{array}$ & Plankton net & $\begin{array}{l}20,328 \\
( \pm 2,324) \mathrm{km}^{-2}\end{array}$ & 0.0041 & Law et al. (2010) \\
\hline \multirow[t]{2}{*}{ North Atlantic } & \multirow{2}{*}{$\begin{array}{l}\text { Continuous } \\
\text { plankton } \\
\text { recorder (CPR) }\end{array}$} & $\begin{array}{l}\text { 1960-1980: } \\
0.01 \mathrm{~m}^{-3}\end{array}$ & 0.01 & \multirow[t]{2}{*}{$\begin{array}{l}\text { Thompson et al. } \\
\text { (2004) }\end{array}$} \\
\hline & & $\begin{array}{l}\text { 1980-2000: } \\
0.04 \mathrm{~m}^{-3}\end{array}$ & 0.04 & \\
\hline \multicolumn{5}{|c|}{ Northwest Atlantic } \\
\hline $\begin{array}{l}\text { Northwest } \\
\text { Atlantic }\end{array}$ & Neuston net & $\mathrm{a} 490 \mathrm{~km}^{-2}$ & 0.00098 & Wilber (1987) \\
\hline $\begin{array}{l}\text { Block Island } \\
\text { Sound, USA }\end{array}$ & Plankton net & $\begin{array}{l}\text { Range: } \\
\text { 14-543 } \mathrm{m}^{-3}\end{array}$ & $14-543$ & $\begin{array}{l}\text { Austin and } \\
\text { Stoops-Glass } \\
\text { (1977) } \\
\end{array}$ \\
\hline Gulf of Maine & Plankton net & $\begin{array}{l}1534 \\
( \pm 200) \mathrm{km}^{-2}\end{array}$ & 0.00031 & Law et al. (2010) \\
\hline $\begin{array}{l}\text { New England, } \\
\text { USA }\end{array}$ & Plankton net & $\begin{array}{l}\text { Mean ranges: } \\
0.00-2.58 \mathrm{~m}^{-3}\end{array}$ & $0.00-2.58$ & $\begin{array}{l}\text { Carpenter et al. } \\
\text { (1972) }\end{array}$ \\
\hline $\begin{array}{l}\text { Continental } \\
\text { shelf, west coast } \\
\text { USA }\end{array}$ & Neuston net & $2,773 \mathrm{~km}^{-2}$ & 0.00056 & $\begin{array}{l}\text { Colton et al. } \\
\text { (1974) }\end{array}$ \\
\hline $\begin{array}{l}\text { Western } \\
\text { Sargasso Sea }\end{array}$ & Neuston net & $3,537 \mathrm{~km}^{-2}$ & 0.00071 & $\begin{array}{l}\text { Carpenter and } \\
\text { Smith (1972) }\end{array}$ \\
\hline \multicolumn{5}{|l|}{ Caribbean Sea } \\
\hline Caribbean & Neuston net & $60.6-180 \mathrm{~km}^{-2}$ & $\begin{array}{l}0.000012- \\
0.000036\end{array}$ & $\begin{array}{l}\text { Colton et al. } \\
\text { (1974) }\end{array}$ \\
\hline Caribbean & Plankton net & $\begin{array}{l}1,414 \\
( \pm 112) \mathrm{km}^{-2}\end{array}$ & 0.00028 & Law et al. (2010) \\
\hline \multicolumn{5}{|c|}{ Northeast Atlantic } \\
\hline Offshore, Ireland & $\begin{array}{l}\text { Underway } \\
\text { sampling }\end{array}$ & $2.46 \mathrm{~m}^{-3}$ & 2.46 & $\begin{array}{l}\text { Lusher et al. } \\
\text { (2014) }\end{array}$ \\
\hline $\begin{array}{l}\text { English Channel, } \\
\text { U.K. }\end{array}$ & Plankton net & $0.27 \mathrm{~m}^{-3}$ & 0.27 & $\begin{array}{l}\text { Cole et al. } \\
(2014 a)\end{array}$ \\
\hline $\begin{array}{l}\text { Bristol Channel, } \\
\text { U.K. }\end{array}$ & $\begin{array}{l}\text { Lowestoft } \\
\text { plankton } \\
\text { sampler }\end{array}$ & $\begin{array}{l}\text { Range: } \\
0-100 \mathrm{~m}^{-3}\end{array}$ & $0->100$ & $\begin{array}{l}\text { Morris and } \\
\text { Hamilton (1974) }\end{array}$ \\
\hline $\begin{array}{l}\text { Severn Estuary, } \\
\text { U.K. }\end{array}$ & & & & $\begin{array}{l}\text { Kartar et al. } \\
(1973,1976)\end{array}$ \\
\hline Portuguese coast & $\begin{array}{l}\text { Neuston net/ } \\
\text { CPR }\end{array}$ & $0.02-0.036 \mathrm{~m}^{-3}$ & $0.02-0.036$ & Frias et al. (2014) \\
\hline \multicolumn{5}{|c|}{ Equatorial Atlantic } \\
\hline $\begin{array}{l}\text { St. Peter } \\
\text { and St. Paul } \\
\text { Archipelago, } \\
\text { Brazil }\end{array}$ & Plankton net & $0.01 \mathrm{~m}^{-3}$ & 0.01 & $\begin{array}{l}\text { Ivar do Sul et al. } \\
\text { (2013) }\end{array}$ \\
\hline
\end{tabular}


Table 10.3 (continued)

\begin{tabular}{l|l|l|l|l}
\hline Location & Equipment used & Amount $( \pm \mathrm{SD})$ & Particles $\left(\mathrm{m}^{-3}\right)$ & Source \\
\hline $\begin{array}{l}\text { South Atlantic } \\
\begin{array}{l}\text { South Atlantic } \\
\text { Bight }\end{array}\end{array}$ & Neuston net & $\begin{array}{l}\text { Mean weight: } \\
0.03-0.08 \mathrm{mg} \mathrm{m}^{-2}\end{array}$ & & $\begin{array}{l}\text { van Dolah et al. } \\
(1980)\end{array}$ \\
\hline $\begin{array}{l}\text { Cape Basin, } \\
\text { South Atlantic }\end{array}$ & Neuston sledge & $1,874.3 \mathrm{~km}^{-2}$ & 0.00037 & Morris (1980) \\
\hline $\begin{array}{l}\text { Cape Province, } \\
\text { South Africa }\end{array}$ & Neuston net & $3,640 \mathrm{~km}^{-2}$ & 0.00073 & Ryan (1988) \\
\hline $\begin{array}{l}\text { Fernando } \\
\text { de Noronha, } \\
\begin{array}{l}\text { Abrolhos and } \\
\text { Trindade, Brazil }\end{array}\end{array}$ & Manta net & $0.03 \mathrm{~m}^{-3}$ & 0.03 & $\begin{array}{l}\text { Ivar do Sul et al. } \\
(2014)\end{array}$ \\
\hline $\begin{array}{l}\text { Gioana estuary, } \\
\text { Brazil }\end{array}$ & $\begin{array}{l}\text { Conical } \\
\text { plankton net }\end{array}$ & $26.04-100 \mathrm{~m}^{-3}$ & 0.26 & $\begin{array}{l}\text { Lima et al. } \\
(2014)\end{array}$ \\
\hline
\end{tabular}

If particles in $\mathrm{m}^{-3}$ were not reported, the values have been converted as follows: (1) $\mathrm{km}^{-2}$ to $\mathrm{m}^{-2}$ : by division by 1,000000 , followed by multiplication by $0.2 \mathrm{~m}$; (2) $\mathrm{m}^{-2}$ to $\mathrm{m}^{-3}$ carried out multiplication by 0.2

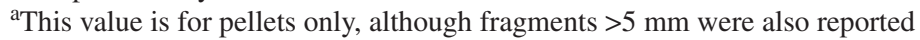

Table 10.4 Mean microplastic abundance ( \pm SD, unless stated otherwise) in sediments from the Atlantic

\begin{tabular}{|c|c|c|c|}
\hline Location & Types & Amount & Source \\
\hline \multicolumn{4}{|l|}{ North Atlantic } \\
\hline Nova Scotia, Canada & Pellets & Max: $<10 \mathrm{~m}^{-1}$ & Gregory (1983) \\
\hline Nova Scotia, Canada & Fibres & $200-800$ fibres $\mathrm{kg}^{-1}$ & $\begin{array}{l}\text { Mathalon and Hill } \\
\text { (2014) }\end{array}$ \\
\hline Beaches, eastern USA & Pellets & & Ogata et al. (2009) \\
\hline $\begin{array}{l}\text { Factory beaches, New } \\
\text { York, USA }\end{array}$ & Spheres & & $\begin{array}{l}\text { Hays and Cormons } \\
\text { (1974) }\end{array}$ \\
\hline *Maine, USA & Pellets and fragments & $105 \mathrm{~kg}^{-1}$ & $\begin{array}{l}\text { Graham and } \\
\text { Thompson (2009) }\end{array}$ \\
\hline *Florida, USA & Pellets and fragments & $214 \mathrm{~kg}^{-1}$ & $\begin{array}{l}\text { Graham and } \\
\text { Thompson (2009) }\end{array}$ \\
\hline Florida Keys, USA & Pellets and fragments & $100-1,000 \mathrm{~m}^{-2}$ & Wilber (1987) \\
\hline Cape Cod, USA & Pellets and fragments & $100-1,000 \mathrm{~m}^{-2}$ & Wilber (1987) \\
\hline North Carolina, USA & Fragments $<5 \mathrm{~cm}$ & $\begin{array}{l}60 \% \text { of debris in size } \\
\text { class }\end{array}$ & Viehman et al. (2011) \\
\hline Bermuda & Pellets & $>5,000 \mathrm{~m}^{-1}$ & Gregory (1983) \\
\hline Bermuda & Pellets and fragments & $2,000-10,000 \mathrm{~m}^{-2}$ & Wilber (1987) \\
\hline \multirow[t]{2}{*}{ Bahamas } & \multirow[t]{2}{*}{ Pellets and fragments } & $\begin{array}{l}\text { Windward: } \\
500-1,000 \mathrm{~m}^{-2}\end{array}$ & \multirow[t]{2}{*}{ Wilber (1987) } \\
\hline & & $\begin{array}{l}\text { Leeward: } \\
200-500 \mathrm{~m}^{-2}\end{array}$ & \\
\hline \multirow[t]{2}{*}{ Lesser Antilles } & \multirow[t]{2}{*}{ Pellets and fragments } & $\begin{array}{l}\text { Windward: } \\
100-5,000 \mathrm{~m}^{-2}\end{array}$ & \multirow[t]{2}{*}{ Wilber (1987) } \\
\hline & & $\begin{array}{l}\text { Leeward: } \\
50-100 \mathrm{~m}^{-2}\end{array}$ & \\
\hline
\end{tabular}


Table 10.4 (continued)

\begin{tabular}{|c|c|c|c|}
\hline Location & Types & Amount & Source \\
\hline Le Havre, France & Pellets & & Endo et al. (2013) \\
\hline Costa Nova, Portugal & Pellets & & Ogata et al. (2009) \\
\hline Lisbon, Portugal & Fibres and pellets & & Frias et al. (2010) \\
\hline Portuguese coast & Pellets and fragments & $185.1 \mathrm{~m}^{-2}$ & $\begin{array}{l}\text { Martins and Sobral } \\
(2011)\end{array}$ \\
\hline Portuguese coast & Pellets $3-6 \mathrm{~mm}$ & $1,289 \mathrm{~m}^{-2}$ & Antunes et al. (2013) \\
\hline $\begin{array}{l}\text { *Porcupine abyssal } \\
\text { plain }\end{array}$ & Fragments & a 40 item $\mathrm{m}^{-2}$ & $\begin{array}{l}\text { Van Cauwenberghe } \\
\text { et al. (2013b) }\end{array}$ \\
\hline Canary Islands, Spain & $\begin{array}{l}\text { Pellets and fragments } \\
<5 \mathrm{~mm}\end{array}$ & $\begin{array}{l}<1 \mathrm{~g} \mathrm{~kg}^{-1}- \\
>40 \mathrm{~g} \mathrm{~kg}^{-1}\end{array}$ & Baztan et al. (2014) \\
\hline \multicolumn{4}{|l|}{ English Channel } \\
\hline $\begin{array}{l}\text { Estuarine sediment, } \\
\text { U.K. }\end{array}$ & Fragments and fibres & Maximum: $31 \mathrm{~kg}^{-1}$ & $\begin{array}{l}\text { Thompson et al. } \\
\text { (2004) }\end{array}$ \\
\hline $\begin{array}{l}\text { *Subtidal sediments, } \\
\text { U.K. }\end{array}$ & Fragments and fibres & Maximum: $86 \mathrm{~kg}^{-1}$ & $\begin{array}{l}\text { Thompson et al. } \\
\text { (2004) }\end{array}$ \\
\hline Plymouth, U.K. & Pellets & & Ogata et al. (2009) \\
\hline South Devon, U.K. & Pellets & $\sim 100$ & Ashton et al. (2010) \\
\hline Tamar estuary, U.K. & Fragments $<1 \mathrm{~mm}$ & $65 \%$ of total debris & Browne et al. (2010) \\
\hline $\begin{array}{l}\text { Southwest England, } \\
\text { U.K. }\end{array}$ & Pellets & $\sim 100$ at each location & Holmes et al. (2012) \\
\hline \multicolumn{4}{|l|}{ South Atlantic } \\
\hline \multirow{3}{*}{$\begin{array}{l}\text { Fernando de } \\
\text { Noronha, Brazil }\end{array}$} & Pellets $23 \%$ & b3.5 $\mathrm{kg}^{-1}$ & \multirow{3}{*}{$\begin{array}{l}\text { Ivar do Sul et al. } \\
\text { (2009) }\end{array}$} \\
\hline & Fragments $65 \%$ & b9.63 $\mathrm{kg}^{-1}$ & \\
\hline & $\begin{array}{l}\text { Nylon monofilament } \\
5 \%\end{array}$ & $\mathrm{~b}_{0.73 \mathrm{~kg}^{-1}}$ & \\
\hline \multirow[t]{2}{*}{ Recife, Brazil } & Fragments $96.7 \%$ & \multirow[t]{2}{*}{$\mathrm{c} 300,000 \mathrm{~m}^{-3}$} & \multirow[t]{2}{*}{ Costa et al. (2010) } \\
\hline & Pellets $3.3 \%$ & & \\
\hline Northeast Brazil & Fragments $1-10 \mathrm{~mm}$ & 59 items $\mathrm{m}^{-3}$ & Costa et al. (2011) \\
\hline *Southern Atlantic & Fragments & a $40{\text { items } \mathrm{m}^{-2}}^{-2}$ & $\begin{array}{l}\text { Van Cauwenberghe } \\
\text { et al. (2013b) }\end{array}$ \\
\hline Santos Bay, Brazil & Pellets & $0-2,500 \mathrm{~m}^{-3}$ & Turra et al. (2014) \\
\hline
\end{tabular}

All sediments are beach sediments unless annotated with *, which refers to benthic or subtidal sediment. d.w. is dry weight of sediment. When originally reported in 1 , values were converted to $\mathrm{kg}$

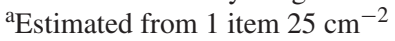

bCalculated from total weight of sand $(13,708 \mathrm{~g})$

${ }^{\mathrm{c} C a l c u l a t e d}$ from 0.3 items $\mathrm{cm}^{-3}$

transported by trans-oceanic currents before being washed ashore in areas such as the mid-Atlantic Archipelago, Fernando de Noronha (Ivar do Sul et al. 2009). Fragments make up a considerable proportion of marine debris on saltmarsh beaches in North Carolina (Viehman et al. 2011), the Canary Islands (Baztan et al. 2014) and beaches and intertidal plains in Brazil (Costa et al. 2010, 2011). Whereas, fibres were primarily identified in sediment samples from an intertidal ecosystem in Nova Scotia, Canada (Mathalon and Hill 2014). 
Table 10.5 Mean microplastic abundance in surface waters of the Mediterranean and European seas

\begin{tabular}{l|l|l|l|l}
\hline Location & Equipment used & Amount & $\begin{array}{l}\text { Particles } \\
\left(\mathrm{m}^{-3}\right)\end{array}$ & Source \\
\hline $\begin{array}{l}\text { West coast, } \\
\text { Sweden }\end{array}$ & $\begin{array}{l}\text { Manta net } \\
(80 \mu \mathrm{m})\end{array}$ & $\begin{array}{l}\text { Range: } \\
150-2,400 \mathrm{~m}^{-3}\end{array}$ & $150-2400$ & Norén (2007) \\
\cline { 2 - 4 } & $\begin{array}{l}\text { Manta net } \\
(450 \mu \mathrm{m})\end{array}$ & $\begin{array}{l}\text { Range: } \\
0.01-0.14 \mathrm{~m}^{-3}\end{array}$ & $0.01-0.14$ & \\
\hline $\begin{array}{l}\text { Skagerrak, } \\
\text { Sweden }\end{array}$ & $\begin{array}{l}\text { Submersible } \\
\text { in situ pump }\end{array}$ & $\begin{array}{l}\text { Maximum: } \\
102,000 \mathrm{~m}^{-3}\end{array}$ & 102,000 & $\begin{array}{l}\text { Norén and } \\
\text { Naustvoll (2011) }\end{array}$ \\
\hline $\begin{array}{l}\text { Northwest } \\
\text { Mediterranean }\end{array}$ & Manta net & $1.33 \mathrm{~m}^{-2}$ & 0.27 & $\begin{array}{l}\text { Collignon et al. } \\
(2012)\end{array}$ \\
\hline $\begin{array}{l}\text { Bay of Calvi, } \\
\text { Corsica, France }\end{array}$ & wp2 net & $0.062 \mathrm{~m}^{-2}$ & 0.012 & $\begin{array}{l}\text { Collignon et al. } \\
(2014)\end{array}$ \\
\hline $\begin{array}{l}\text { Gulf of Oristano, } \\
\text { Sardinia, Italy }\end{array}$ & Manta net & $0.15 \mathrm{~m}^{-3}$ & 0.15 & $\begin{array}{l}\text { de Lucia et al. } \\
(2014)\end{array}$ \\
\hline $\begin{array}{l}\text { North Sea, } \\
\text { Finland }\end{array}$ & Manta net & $\begin{array}{l}\text { Range: } 0-0.74 \\
\mathrm{~m}^{-3}\end{array}$ & $0-0.74$ & Magnusson (2014) \\
\hline
\end{tabular}

If particles in $\mathrm{m}^{-3}$ were not reported, the values have been converted as follows: (1) $\mathrm{km}^{-2}$ to $\mathrm{m}^{-2}$ : by division by $1,000,000$ followed by multiplication by $0.2 \mathrm{~m}$; (2) $\mathrm{m}^{-2}$ to $\mathrm{m}^{-3}$ carried out multiplication by 0.2

\subsubsection{Microplastics in European Seas and the Mediterranean Sea}

Marine litter including microplastic is a serious concern in the Mediterranean, with plastics accounting for 70-80\% of litter identified (Fossi et al. 2014). This enclosed water basin is not free of microplastic contamination (Table 10.5). Levels of microplastics in surface waters of the northwest Mediterranean were similar to those reported for the NPCG, (0.27 particles $\mathrm{m}^{-3} 2$ Collignon et al. 2012), and areas far away from point sources of pollution have high microplastic abundance (0.15 particles $\mathrm{m}^{-3}$; de Lucia et al. 2014). Interestingly, fewer particles were recorded from surface waters from coastal Corsica $\left(0.012\right.$ particles $\mathrm{m}^{-3} 3$; Collignon et al. 2014). Microplastic distribution is strongly influenced by wind stress, which may redistribute particles in the upper layers of the water column and preclude sampling by surface tows (Collignon et al. 2012). Oceanographic influences may affect the distribution of microplastics in the Mediterranean. Further research will help to clarify if the new hypothesis by de Lucia et al. (2014) holds, which suggests that upwelling dilutes the amount of plastic in the surface waters.

Microplastics, including beads and pellets, have been widely reported for sedimentary habitats and beaches in European Seas and the Mediterranean Sea (Table 10.6). Microplastics have been extracted from sediments from Norderney, in the North Sea (Dekiff et al. 2014; Fries et al. 2013) and samples taken at the East Frisian

\footnotetext{
${ }^{2}$ Calculated from 1.334 particles $\mathrm{m}^{-2}$.

${ }^{3}$ Calculated from 0.062 particles $\mathrm{m}^{-2}$.
} 
Table 10.6 Mean microplastic abundance ( \pm SD, unless stated otherwise) in sediments from the Mediterranean and European seas

\begin{tabular}{|c|c|c|c|}
\hline Location & Types & Amount & Source \\
\hline \multicolumn{4}{|l|}{ North Sea } \\
\hline $\begin{array}{l}\text { Harbor sediment, } \\
\text { Sweden }\end{array}$ & Fragments & a2 20 and $50 \mathrm{~kg}^{-1}$ & Norén (2007) \\
\hline $\begin{array}{l}\text { Industrial harbor } \\
\text { sediment, Sweden }\end{array}$ & Pellets & a $3320 \mathrm{~kg}^{-1}$ & Norén (2007) \\
\hline $\begin{array}{l}\text { Industrial coastal } \\
\text { sediment, Sweden }\end{array}$ & Pellets & ${ }^{a} 340 \mathrm{~kg}^{-1}$ & Norén (2007) \\
\hline Spiekeroog, Germany & Fibres and granules & ${ }^{b_{3}, 800 \mathrm{~kg}^{-1} \text { d.w. }}$ & $\begin{array}{l}\text { Liebezeit and Dubaish } \\
\text { (2012) }\end{array}$ \\
\hline \multirow[t]{2}{*}{ Jade System, Germany } & Fibres & $88( \pm 82) \mathrm{kg}^{-1}$ & \multirow{2}{*}{$\begin{array}{l}\text { Dubaish and Liebezeit } \\
\text { (2013) }\end{array}$} \\
\hline & Granules & $64( \pm 194) \mathrm{kg}^{-1}$ & \\
\hline Norderney, Germany & Fragments & 1 & Fries et al. (2013) \\
\hline Norderney, Germany & Fragments & $1.3,1.7,2.3 \mathrm{~kg}^{-1}$ d.w. & Dekiff et al. (2014) \\
\hline $\begin{array}{l}\text { Zandervoord, } \\
\text { Netherlands }\end{array}$ & Pellets & I & Ogata et al. (2009) \\
\hline *Harbor, Belgium & $\begin{array}{l}\text { Fibres, granules, films, } \\
\text { spheres }\end{array}$ & $\begin{array}{l}116.7( \pm 92.1) \\
\mathrm{kg}^{-1} \text { d.w. }\end{array}$ & Claessens et al. (2011) \\
\hline $\begin{array}{l}\text { *Continental shelf, } \\
\text { Belgium }\end{array}$ & Fibres, granules, films & $97.2( \pm 18.6) \mathrm{kg}^{-1}$ d.w. & Claessens et al. (2011) \\
\hline Beach, Belgium & Fibres, granules, films & $92.8( \pm 37.2) \mathrm{kg}^{-1}$ d.w. & Claessens et al. (2011) \\
\hline Beach, Belgium & Pellets and fragments & $17( \pm 11) \mathrm{kg}^{-1}$ & $\begin{array}{l}\text { Van Cauwenberghe et al. } \\
\text { (2013a) }\end{array}$ \\
\hline Forth estuary, U.K. & Pellets & I & Ogata et al. (2009) \\
\hline \multicolumn{4}{|l|}{ Mediterranean Sea } \\
\hline 8 beaches, Malta & Pellets & $0.7-167 \mathrm{~m}^{-2}$ & $\begin{array}{l}\text { Turner and Holmes } \\
\text { (2011) }\end{array}$ \\
\hline Sicily, Italy & Pellets & 1 & Ogata et al. (2009) \\
\hline Venice lagoon, Italy & Fragments and fibres & $672-2,175 \mathrm{~kg}^{-1}$ d.w. & Vianello et al. (2013) \\
\hline $\begin{array}{l}\text { *Nile deep sea fan, } \\
\text { Mediterranean }\end{array}$ & Fragments & ${ }^{\mathrm{c}} 40{\text { items } \mathrm{m}^{-2}}^{-2}$ & $\begin{array}{l}\text { Van Cauwenberghe et al. } \\
\text { (2013b) }\end{array}$ \\
\hline Lesvos, Greece & Pellets & 1 & $\begin{array}{l}\text { Karapangioti and Klontza } \\
\text { (2007) }\end{array}$ \\
\hline Kato Achaia, Greece & Pellets & 1 & Ogata et al. (2009) \\
\hline Beaches, Greece & Pellets & 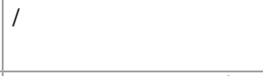 & $\begin{array}{l}\text { Karapanagioti et al. } \\
\text { (2011) }\end{array}$ \\
\hline Kea Island, Greece & Pellets & $10,43,218,575 \mathrm{~m}^{-2}$ & Kaberi et al. (2013) \\
\hline Tripoli-Tyre, Lebanon & Pellets and fragments & 1 & Shiber (1979) \\
\hline Costa del Sol, Spain & Pellets & I & Shiber (1982) \\
\hline $\begin{array}{l}18 \text { beaches, western } \\
\text { Spain }\end{array}$ & Pellets & 1 & Shiber (1987) \\
\hline Izmir, Turkey & Pellets & I & Ogata et al. (2009) \\
\hline
\end{tabular}

All sediments are beach sediments unless annotated with *, which refers to benthic or subtidal sediment. d.w. is dry weight of sediment. When originally reported in 1 , values were converted to $\mathrm{kg}$ ${ }^{\mathrm{a} C}$ Calculated from $100 \mathrm{ml}$ sediment

${ }^{\mathrm{b}}$ Calculated from $10 \mathrm{~g}$ sediment

'Estimated from 1 item $25 \mathrm{~cm}^{-2}$ 
Islands, where tidal flats were more contaminated than sandy beaches (Liebezeit and Dubaish 2012). Areas of low hydrodynamics appear to have high microplastic abundance, such as the Venice lagoon (Vianello et al. 2013). Reduced water movement could also be attributed to the difference between concentrations of microplastics in Belgium: higher concentrations of microplastics were identified in sediments from Belgium harbors (Claessens et al. 2011) than in beach samples (Van Cauwenberghe et al. 2013a). Lastly, microplastics were recorded in deep offshore sediments (Van Cauwenberghe et al. 2013b; Fischer et al. 2015), which shows that microplastics sink to the deep seafloor. In fact, the deep seafloor may be considered a major sink for microplastic debris (Woodall et al. 2014) and explain the current mismatch between estimated global inputs of plastic debris to the oceans (Jambeck et al. 2015) and field data (Cózar et al. 2014; Eriksen et al. 2014), which refer largely to floating litter.

\subsubsection{Microplastics in the Indian Ocean and Marginal Seas}

To date there are few large-scale reports on microplastics from the Indian Ocean. Reddy et al. (2006) reported microplastic fragments from a ship-breaking yard in the Arabian Sea, and microplastics accounted for $20 \%$ of the plastics recorded on sandy beaches in Mumbai (Jayasiri et al. 2013). Pellets were also recorded on

Table 10.7 Mean microplastic abundance ( \pm SD, unless stated otherwise) in sediments from the Indian Ocean and marginal seas

\begin{tabular}{|c|c|c|c|}
\hline Location & Types & Amount & Source \\
\hline \multicolumn{4}{|l|}{ Arabian Sea } \\
\hline $\begin{array}{l}\text { Ship-breaking yard, } \\
\text { Alang-Sosiya, India }\end{array}$ & Fragments & $81 \mathrm{mg} \mathrm{kg}^{-1}$ & Reddy et al. (2006) \\
\hline $\begin{array}{l}\text { Mumbai, Chennai and } \\
\text { Sunderbans, India }\end{array}$ & Pellets & l & Ogata et al. (2009) \\
\hline Mumbai, India & Fragments & $41.85 \%$ of total plastics & Jayasiri et al. (2013) \\
\hline \multicolumn{4}{|c|}{ East Asian Marginal Seas } \\
\hline Coastline, Singapore & Fragments & I & $\mathrm{Ng}$ and Obbard (2006) \\
\hline Coastline, Singapore & $\begin{array}{l}\text { Fibres, grains, } \\
\text { fragments }\end{array}$ & $36.8 \pm 23.6 \mathrm{~kg}^{-1}$ & $\begin{array}{l}\text { Mohamed Nor and } \\
\text { Obbard (2014) }\end{array}$ \\
\hline Selangor, Malaysia & Pellets & $<18 \mathrm{~m}^{-2}$ & Ismail et al. (2009) \\
\hline $\begin{array}{l}\text { Lang Kawi, Penang } \\
\text { and Borneo, Malaysia }\end{array}$ & Pellets & l & Ogata et al. (2009) \\
\hline Rayong, Thailand & Pellets & I & Ogata et al. (2009) \\
\hline Jakarta Bay, Indonesia & Pellets & I & Ogata et al. (2009) \\
\hline Southern Indian Ocean & Pellets & I & Ogata et al. (2009) \\
\hline Mozambique & Pellets & I & Ogata et al. (2009) \\
\hline Gulf of Oman & Pellets & $>50-200 \mathrm{~m}^{-2}$ & \multirow{2}{*}{$\begin{array}{l}\text { Khordagui and Abu- } \\
\text { Hilal (1994) }\end{array}$} \\
\hline Arabian Gulf & Pellets & $>50-80,000 \mathrm{~m}^{-2}$ & \\
\hline
\end{tabular}

All sediments are beach sediments 
Malaysian beaches (Ismail et al. 2009). Most of the studies shown in Table 10.7 are part of the "International Pellet Watch" (Takada 2006; Ogata et al. 2009). Shoreline surveys conducted in surface waters and sediments on Singapore's coasts identified microplastics $>2 \mu \mathrm{m}$ ( $\mathrm{Ng}$ and Obbard 2006). This highlights an area that requires further investigation to obtain a wider picture of microplastic distribution around the globe.

\subsubsection{Microplastics in Polar Regions}

Prior to 2014, there had been no direct studies of microplastics in either the Arctic or Antarctica; the plastic flux into the Arctic Ocean has been calculated to range between 62,000 and 105,000 tons per year, with variation due to spatial heterogeneity, temporal variability and different sampling methods (Zarfl and Matthies 2010). With the estimated value four to six orders of magnitude below the atmospheric transport and ocean current fluxes, the study concluded that plastic transport levels to the Arctic are negligible and that plastics are not a likely vector for organic pollutants to the Arctic. However, Obbard et al. (2014) published results from ice cores collected from remote locations in the Arctic Ocean. The levels of microplastics observed (range: 38-234 particles $\mathrm{m}^{-3}$ ) were two orders of magnitude greater than previously reported in the Pacific gyre (Goldstein et al. 2012). Macroplastics have been identified floating in surface waters of Antarctica. However, trawls for microplastics did not catch any particles (Barnes et al. 2010). Dietary studies of birds from the Canadian Arctic have reported ingested plastics (Mallory et al. 2006; Provencher et al. 2009, 2010), and macroplastics were observed on the deep Arctic seafloor (Bergmann and Klages 2012). This indirect evidence suggests that microplastics have already entered polar regions. A modelling study even suggests the presence or formation of a sixth garbage patch in the Barents Sea (van Sebille et al. 2012).

\subsubsection{Modelling the Distribution of Microplastics}

Studies have highlighted the interaction of oceanographic and environmental variables on the distribution of microplastics (e.g. Eriksen et al. 2013). As polymer densities affect the distribution of plastics in the water column, it is important to understand how microplastics are transported at the surface and at depths. Knowledge of point-source pollution, including riverine input and sewage drainage into marine and coastal environments, can be useful in understanding the extent to which certain ecosystems are affected. Furthermore, knowledge of plastic accumulation on beaches will benefit the study of microplastics. For example, a study of plastic litter washed onto beaches developed a particle tracking model, which indicated that, if levels of plastic outflow remain constant over the coming decade, plastic litter quantity on beaches would continue to increase, and in some cases (3\% of all east Asian beaches) could see a 250 -fold increase in plastic 
litter (Kako et al. 2014). If not removed, these larger items of plastic litter will break down into microplastics over time.

The fate of plastics in the marine environment is affected by poorly understood geophysical processes, including ocean mixing of the sea-surface boundary layer, re-suspension from sediments, and sinking rates plastics denser than seawater. Modelling approaches are required to further understand, and accurately estimate the global distribution, residence time, convergence zones, and ecological consequences of microplastics (Ballent et al. 2013). Models predicting the breakdown, fragmentation, and subsequent mixing and re-suspension of microplastics in sediments and seawater could provide an estimation of microplastic accumulation over short and long time scales; as well as an estimation of the dispersal patterns of microplastics in the marine environment. Generalized linear models have indicated that oceanographic mechanisms may promote topographic trapping of zooplankton and microplastics, which may be retained by small-scale circulation patterns in the Equatorial Atlantic, suggesting there is an outward gradient of microplastics moving offshore (Ivar do Sul et al. 2013). The recovery of plastic from surface seawater is dependent on wind speeds: stronger winds resulted in the capture of fewer plastics because wind-induced mixing of the surface layer vertically distributes plastics (Kulkula et al. 2012). Furthermore, by integrating the effect of vertical wind mixing on the concentrations of plastics in Australian waters, researchers estimated depth-integrated plastic concentrations, with high concentrations expected at low wind speeds. Thus, with the inverse relationship between wind force and plastic concentration, net tow concentrations of microplastics increased by a factor of 2.8 (Reisser et al. 2013).

Ballent et al. (2013) used the MOHID modelling system to predict the dispersal of non-buoyant pellets in Portugal using their density, settling velocity and re-suspension characteristics. Researchers simulated the transport of microplastic pellets over time using oceanographic processes, scales and systems. Model predictions suggest that the bottom topography restricts pellet movement at the head of the Nazare Canyon with a potential area of accumulation of plastics pellets on the seafloor, implying long-term exposure of benthic ecosystems to microplastics. Tidal forces, as well as large-scale oceanographic circulation patterns are likely to transport microplastics up and down the Nazaré Canyon, which may be greatly increased during mass transport of waters linked to storms (Ballent et al. 2013) or deep-water cascading events (Durrieu de Madron et al. 2013).

With residence times from decades to centuries predicted for microplastics in the benthic environment (Ballent et al. 2013), future studies should assess the degradation of microplastics on the seafloor to be able to estimate residence times in those potential sink environments. Coupled with observations of microplastics in surface waters, the total oceanic plastic concentrations might be underestimated because of limited but growing knowledge of the geophysical and oceanographic processes in the surface waters. Furthermore, as microplastics degrade towards a nanometre scale, transport properties may be affected, and as a result, long-term transport models will need to be corrected. Modelling should be adapted to bring in ecological consequences of microplastics in benthic environments and the water column. 
Research should focus on critical areas such as biodiversity hotspots and socio-economic hotspots that could affect vulnerable marine biota and coastal communities.

\subsubsection{Summary}

Microplastics have been documented in almost every habitat of the open oceans and enclosed seas, including beaches, surface waters, water column and the deep seafloor. Although most water bodies have been investigated, there is a lack of published work from polar regions and the Indian Ocean. Further research is required to accurately estimate the amount of different types of microplastics in benthic environments around the globe. Distribution of microplastics depends on environmental conditions including ocean currents, horizontal and vertical mixing, wind mixing and biofilm formation, as well as the properties of individual plastic polymers. A number of modelling approaches have been considered in the recent literature, which highlighted the effect of wind on the distribution of microplastics in the ocean. Oceanographic modelling of floating debris has shown accumulation in ocean gyres, and the distribution of microplastics within the water column appears to be dependent on the composition, density and shape of plastic polymers affecting their buoyancy. Further modelling studies may help to identify and predict regions with ecological communities and fisheries more vulnerable to the potential consequences of plastic contamination. The distribution of microplastic plays a significant role in terms of which organisms and habitats are affected. Widespread accumulation and distribution of microplastics raises concerns regarding the interaction and potential effects on marine organisms.

\subsection{Interactions of Microplastics with Marine Organisms}

Recently, Wright et al. (2013a) discussed the biological factors, which could enhance microplastic bioavailability to marine organisms: the varying density of microplastics allows them to occupy different areas of the water column and benthic sediments. As microplastics interact with plankton and sediment particles, both suspension and deposit feeders may be at risk of accidentally or selectively ingesting marine debris. However, the relative impacts are likely to vary across the size spectrum of microplastic in relation to the organisms affected, which is dependent on the size of the microplastic particles encountered. Microplastics in the upper end of the size spectrum (1-5 mm) may compromise feeding and digestion. For example, Codina-García et al. (2013) isolated such pellets and fragments from the stomachs of seabirds. Particles $<20 \mu \mathrm{m}$ are actively ingested by small invertebrates (e.g. Thompson et al. 2004) but they are also egested (e.g. Lee et al. 2013). Studies have shown that nanoparticles can translocate (e.g. Wegner et al. 2012) 
and model simulations have indicated that nano-sized polystyrene (PS) particles may permeate into the lipid membranes of organisms, altering the membrane structure, membrane protein activity, and therefore cellular function (Rossi et al. 2013). The following section deals with incidences of ingestion, trophic transfer and provision of new habitat by the presence of microplastics in the marine environment. Although the sections contain examples, comprehensive lists of microplastics ingestion are included in the corresponding tables.

\subsubsection{Ingestion}

Ingestion is the most likely interaction between marine organisms and microplastics. Microplastics' small size gives them the potential to be ingested by a wide range of biota in benthic and pelagic ecosystems. In some cases, organisms feeding mechanisms do not allow for discrimination between prey and anthropogenic items (Moore et al. 2001). Secondly, organisms might feed directly on microplastics, mistaking them for prey or selectively feed on microplastics in place of food (Moore 2008). If there is a predominance of microplastic particles associated with planktonic prey items, organisms could be unable to differentiate or prevent ingestion. A number of studies have reported microplastics from the stomachs and intestines of marine organisms, including fish and invertebrates. Watts et al. (2014) showed that shore crabs (Carcinus maenas) will not only ingest microplastics along with food (evidence in the foregut) but also draw plastics into the gill cavity because of their ventilation mechanism: this highlights that it is important to consider all sorts of routes of exposure to microplastics. If organisms ingest microplastics they could have adverse effects on individuals by disrupting feeding and digestion (GESAMP 2010). Laboratory (Table 10.8) and field (Table 10.9) studies highlighted that microplastics are mistaken for food by a wide variety of animals including birds, fish, turtles, mammals and invertebrates. Despite concerns raised regarding microplastic ingestion, few studies specifically examined the occurrence of microplastic in natural, in situ, populations as it is methodologically challenging to assess microplastic ingestion in the field (Browne et al. 2008).

\subsubsection{Planktonic Invertebrates}

Microplastics can enter the very base of the marine food web via absorption. Such was observed when charged nano-polystyrene beads were absorbed into the cellulose of a marine alga (Scenedesmus spp.), which inhibited photosynthesis and caused oxidative stress (Bhattacharya et al. 2010). Microplastics can also affect the function and health of marine zooplankton (Cole et al. 2013; Lee et al. 2013). Decreased feeding was observed following ingestion of polystyrene beads by zooplankton (Cole et al. 2013). Furthermore, adult females and nauplius larvae of the copepod (Tigriopus japonicus) survived acute exposure, but increased 


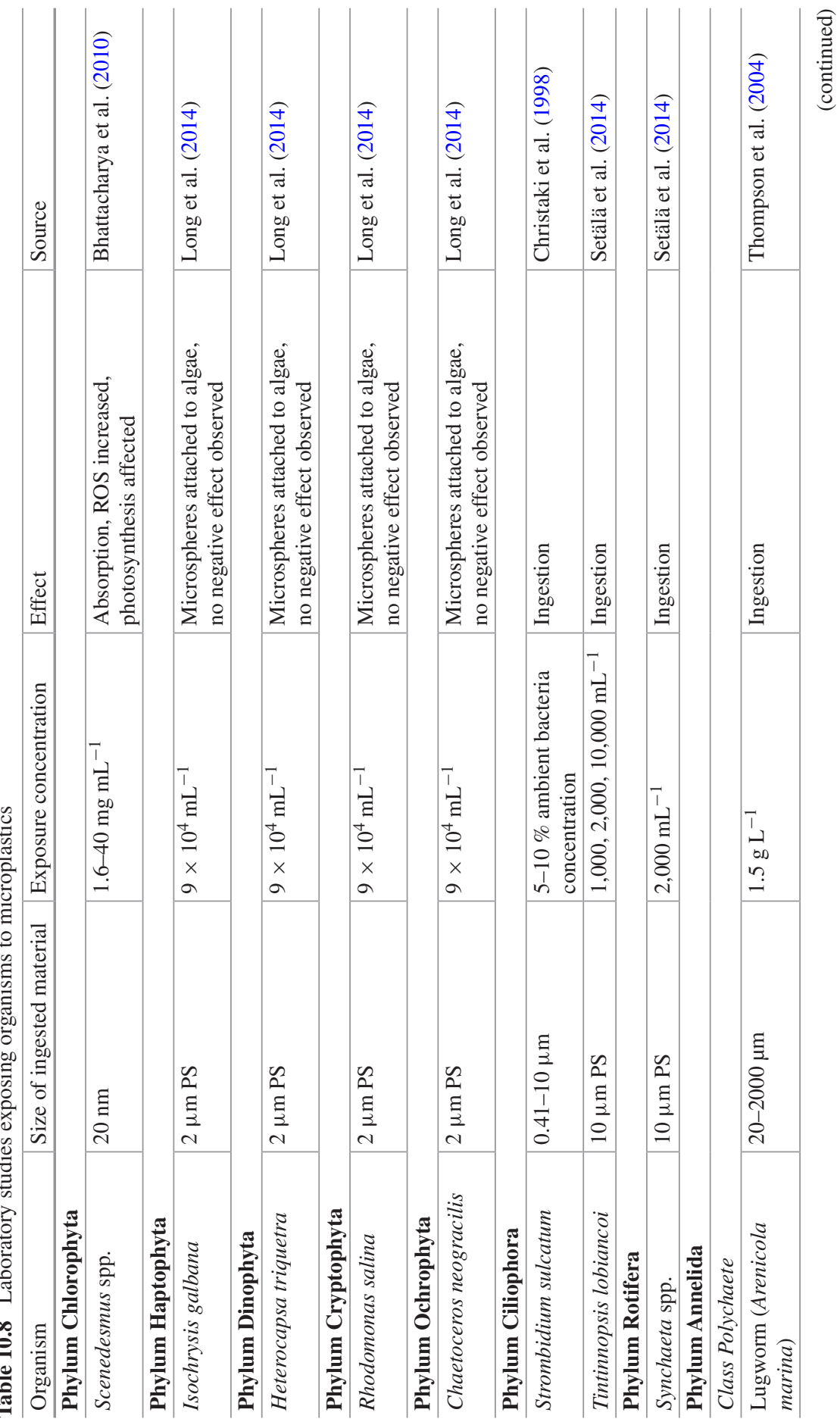


A. Lusher

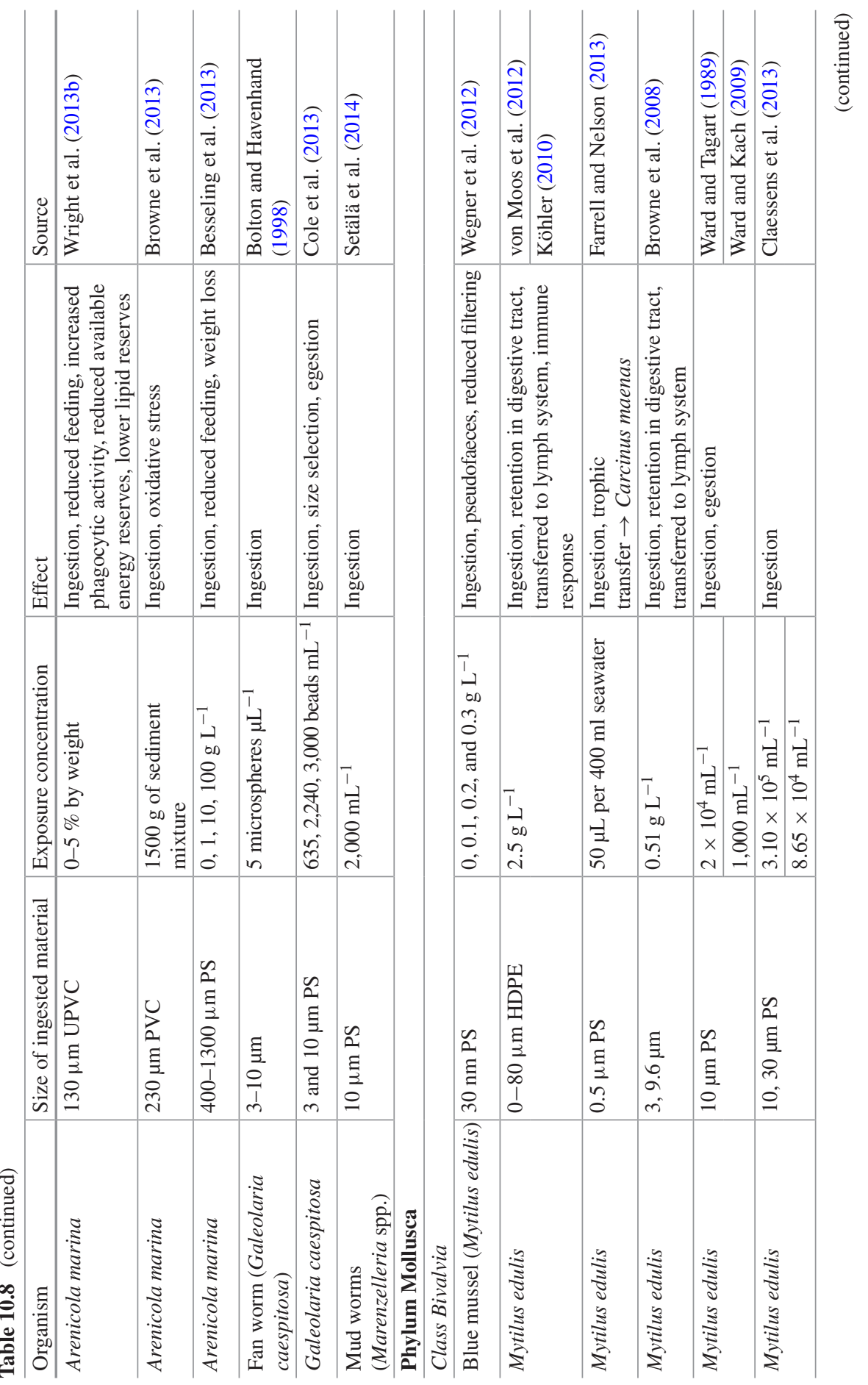




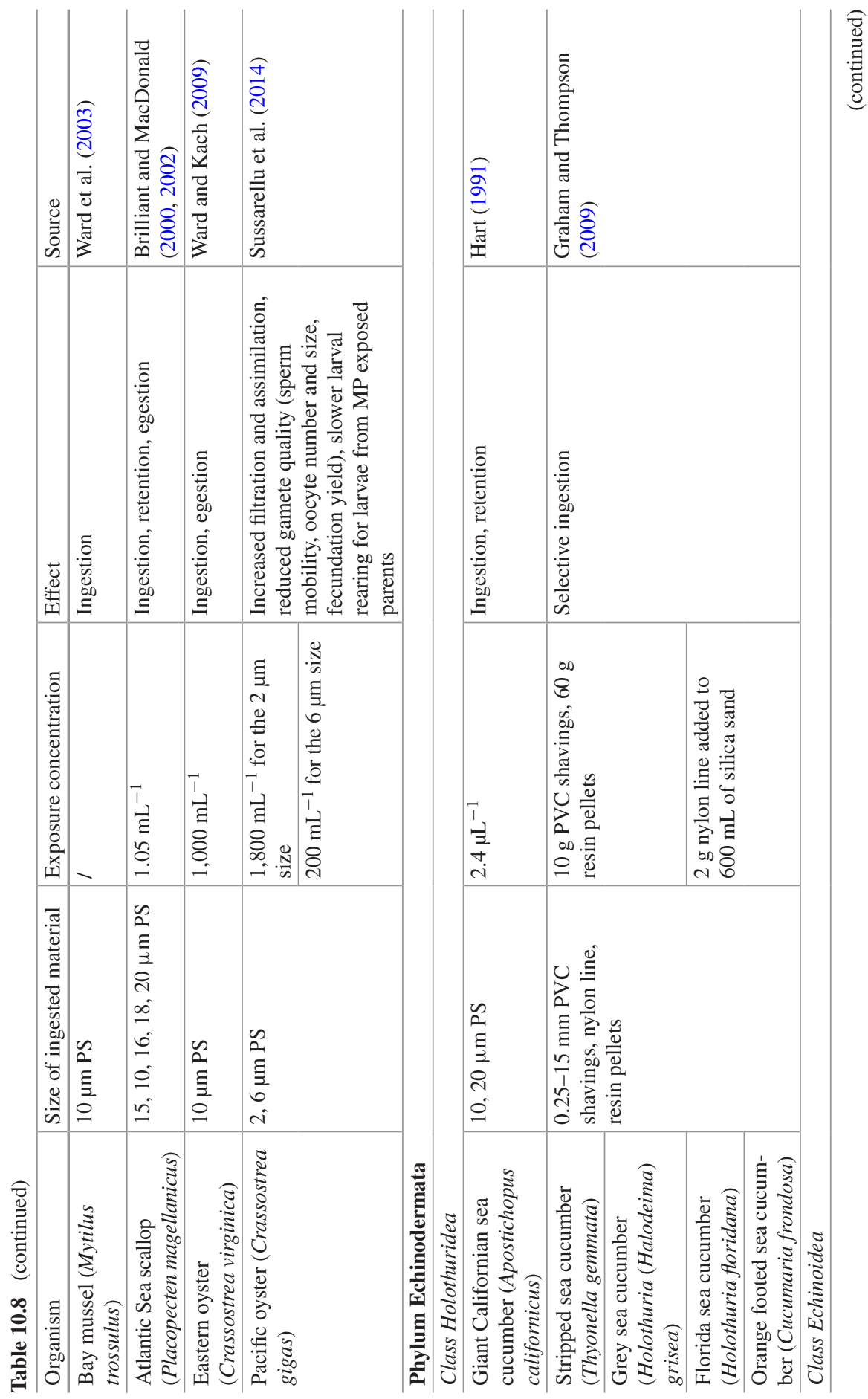


A. Lusher

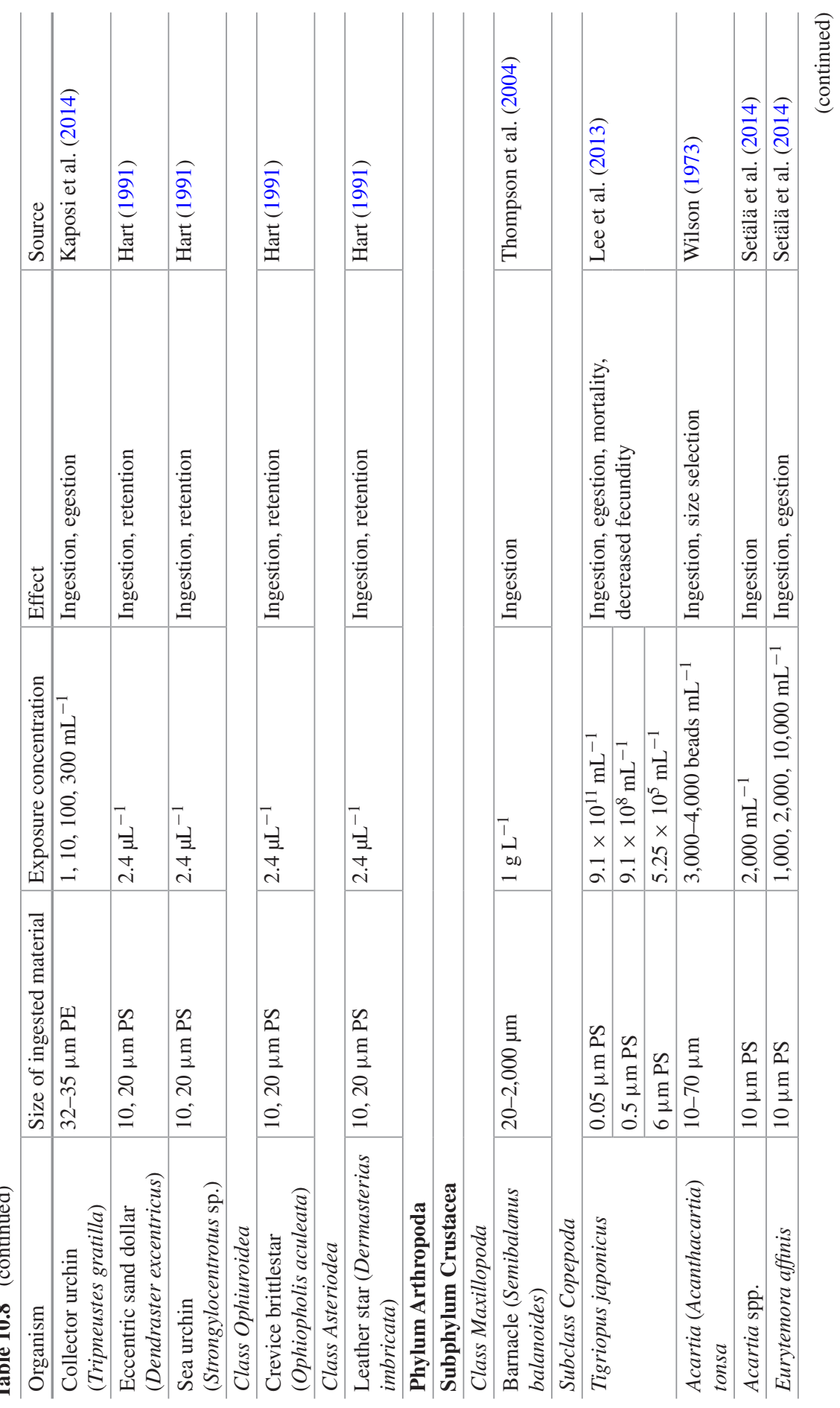




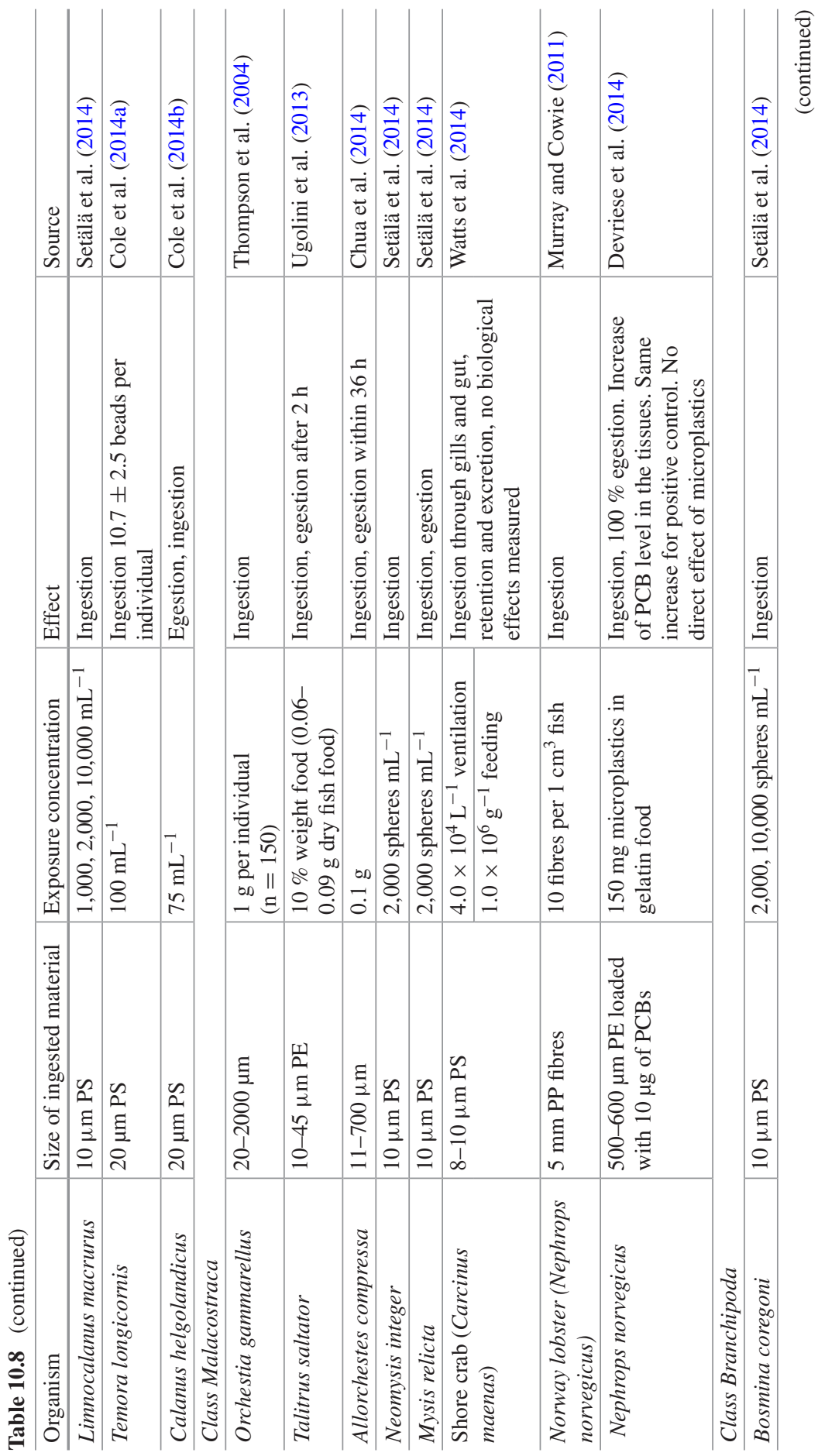


A. Lusher

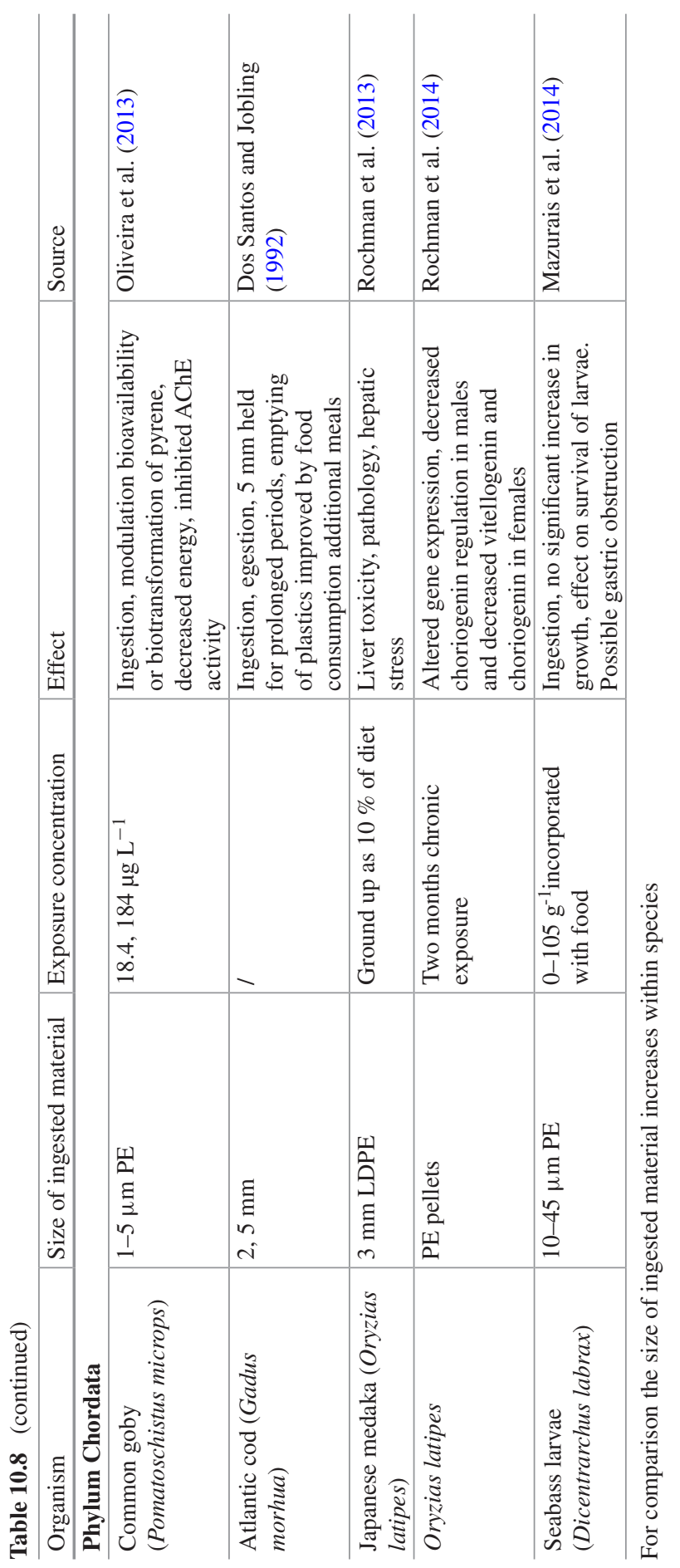




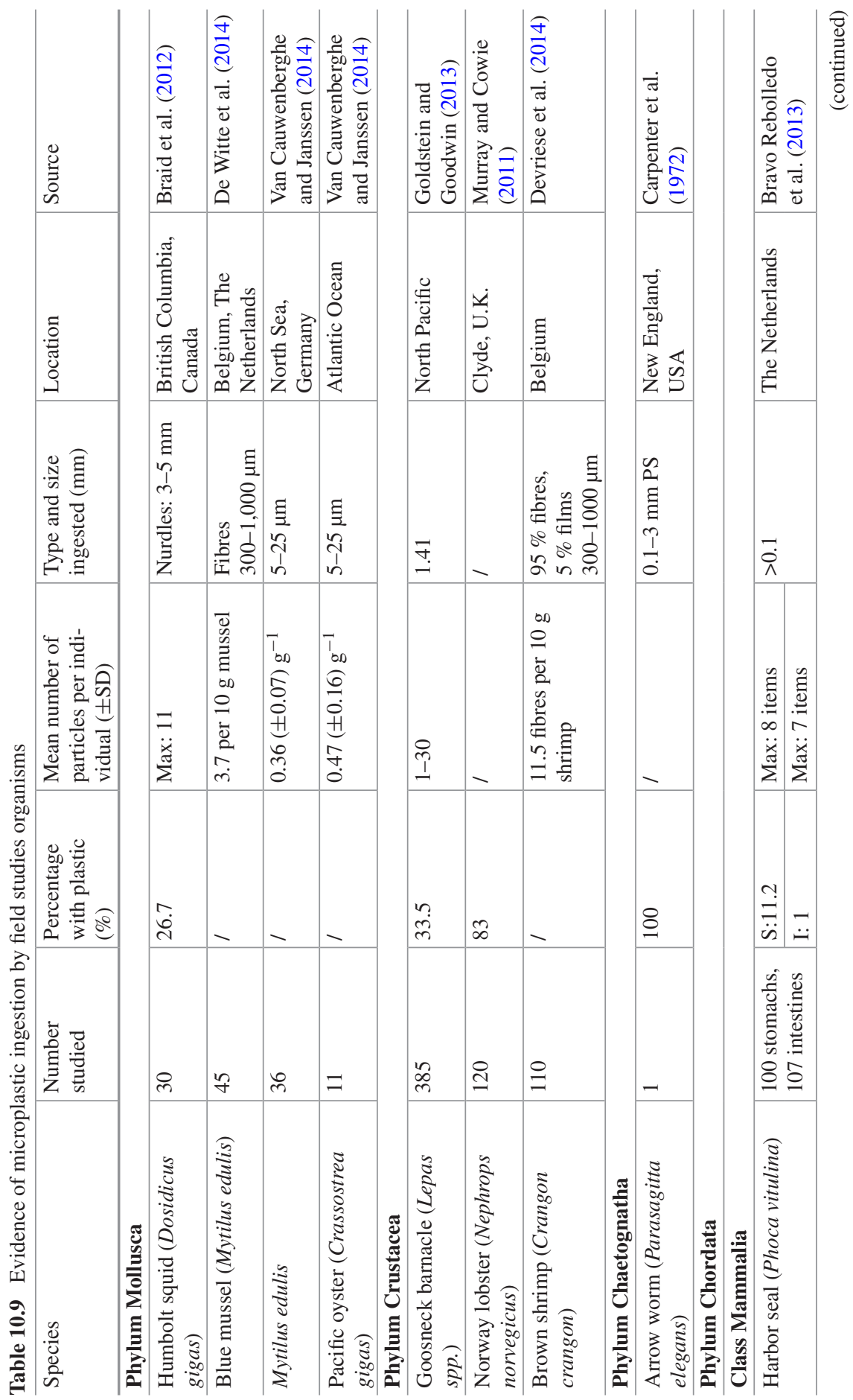


A. Lusher

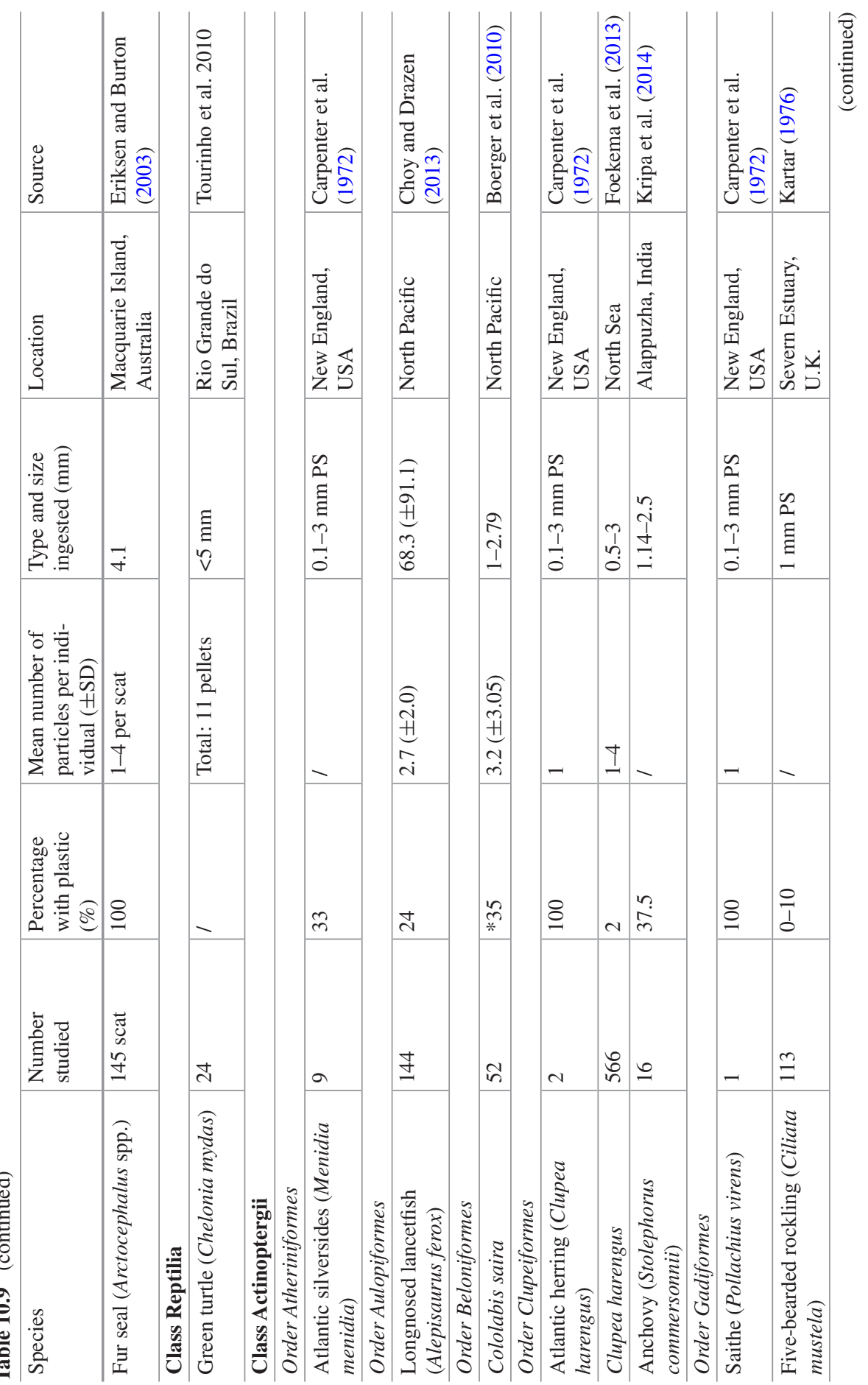




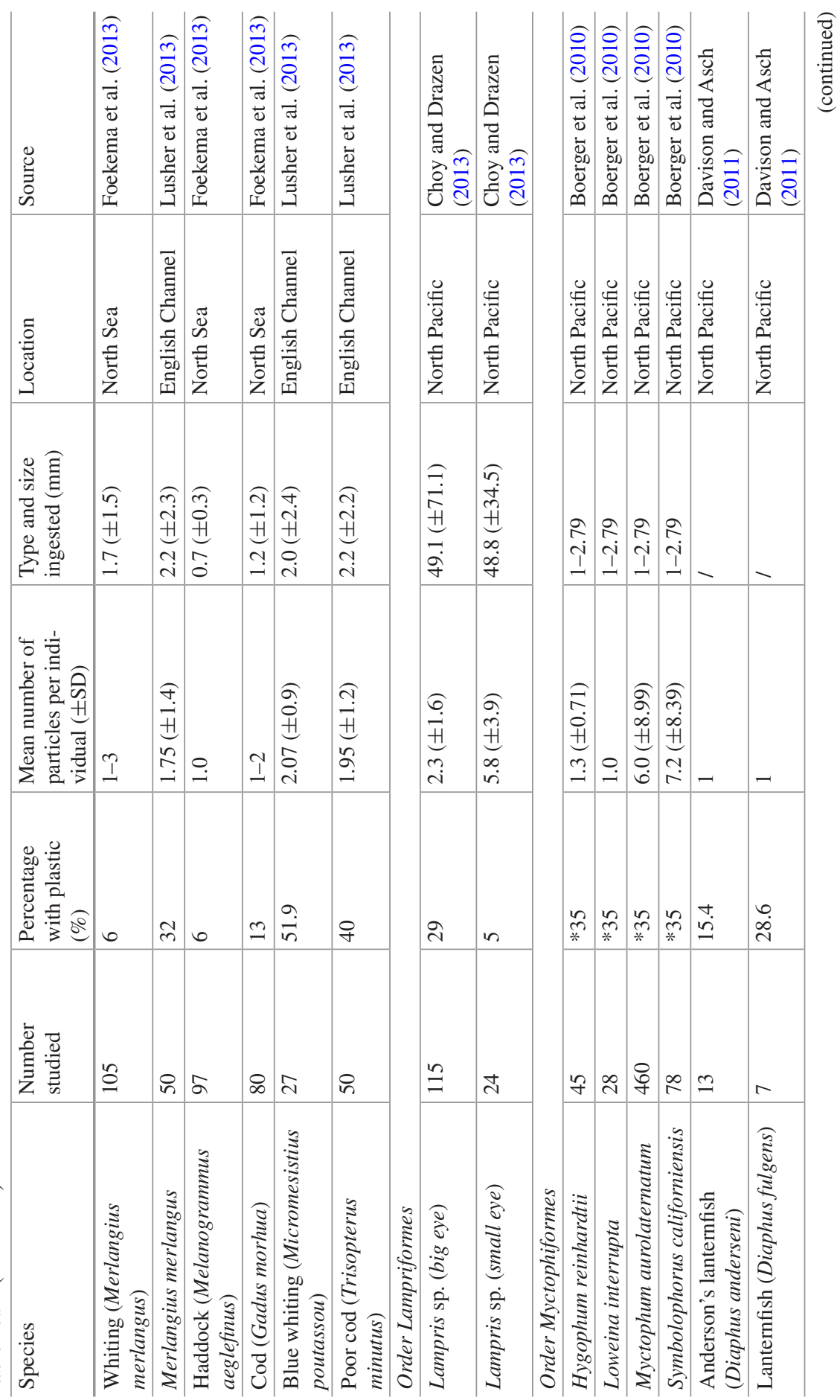


A. Lusher

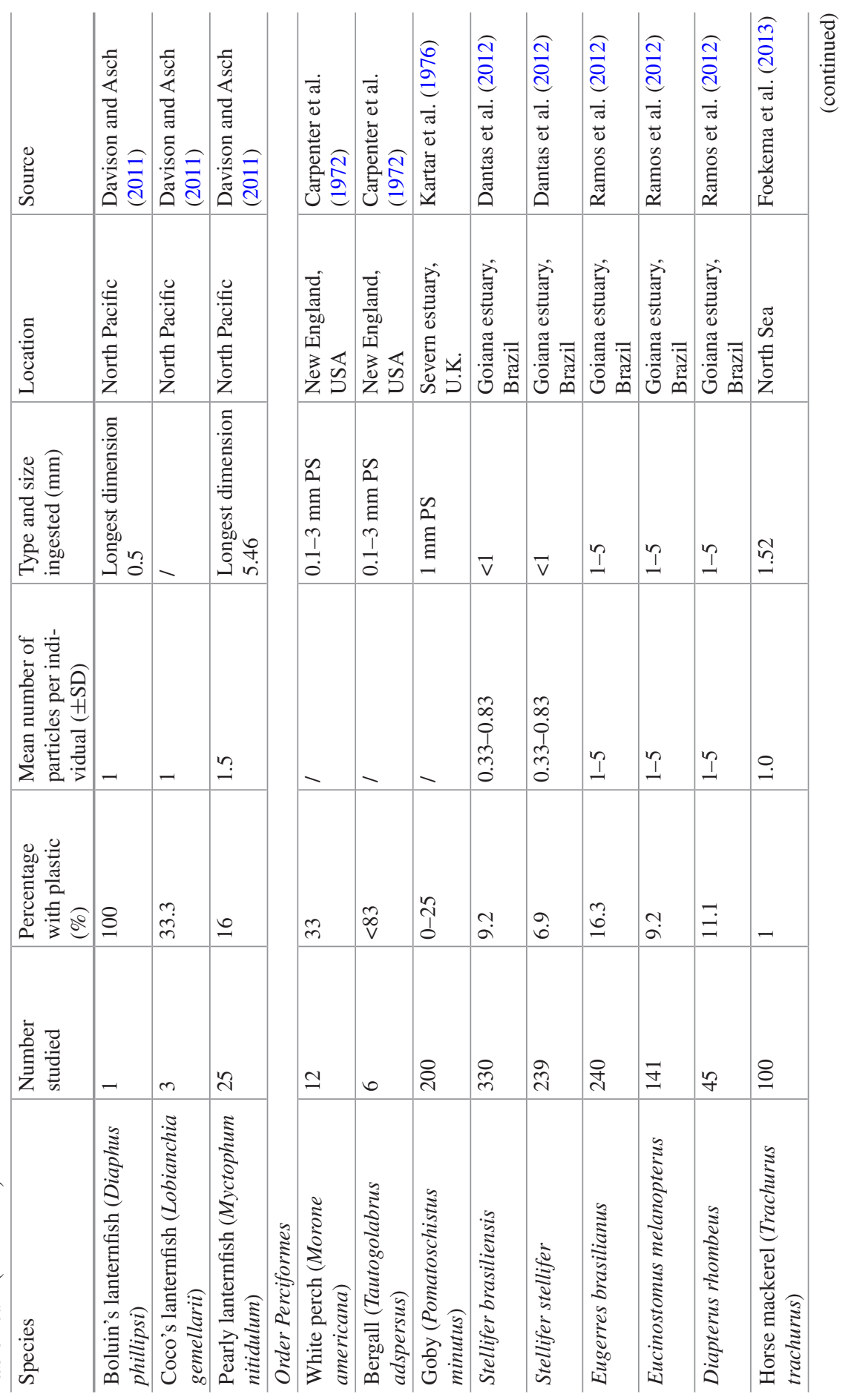




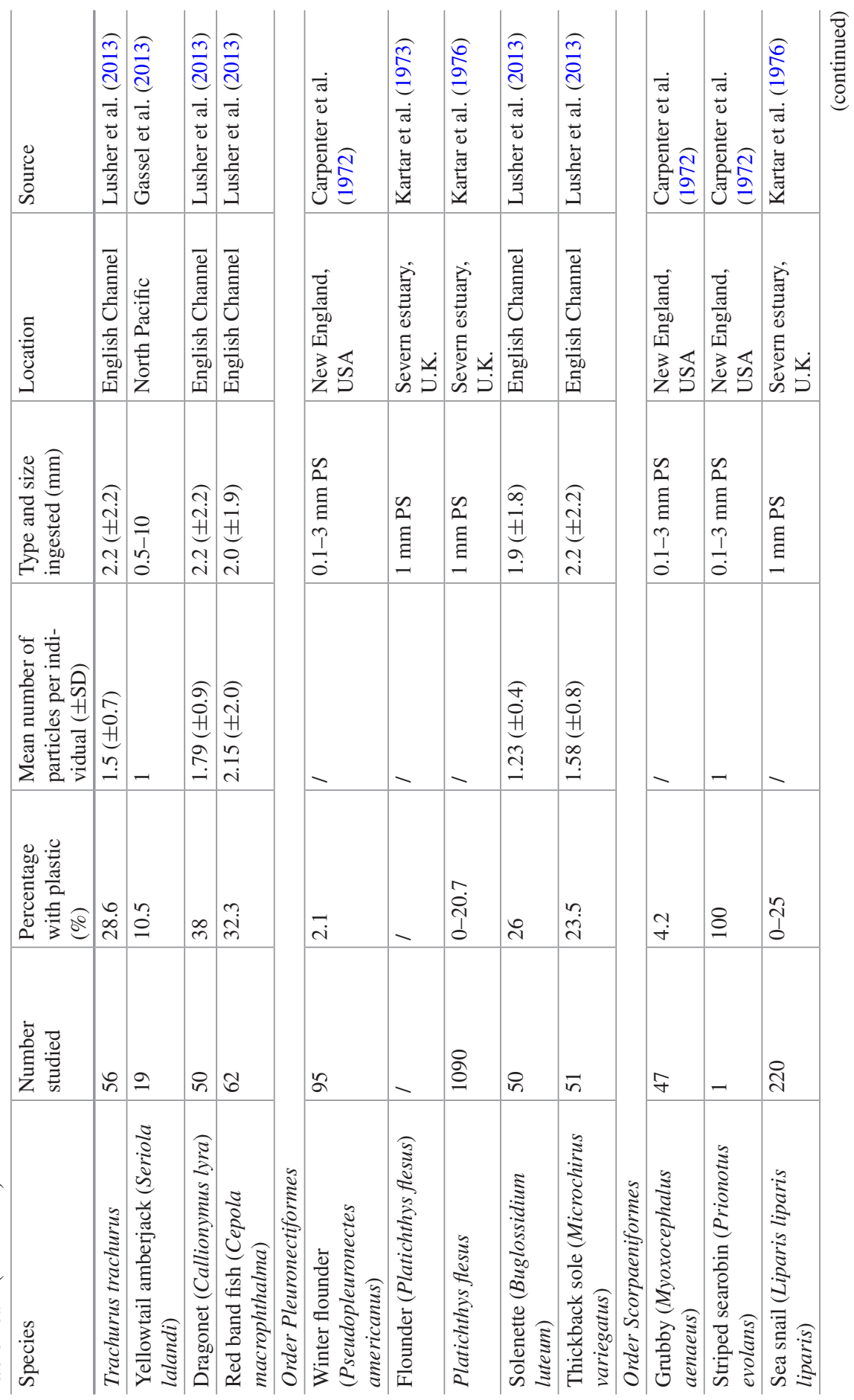


A. Lusher

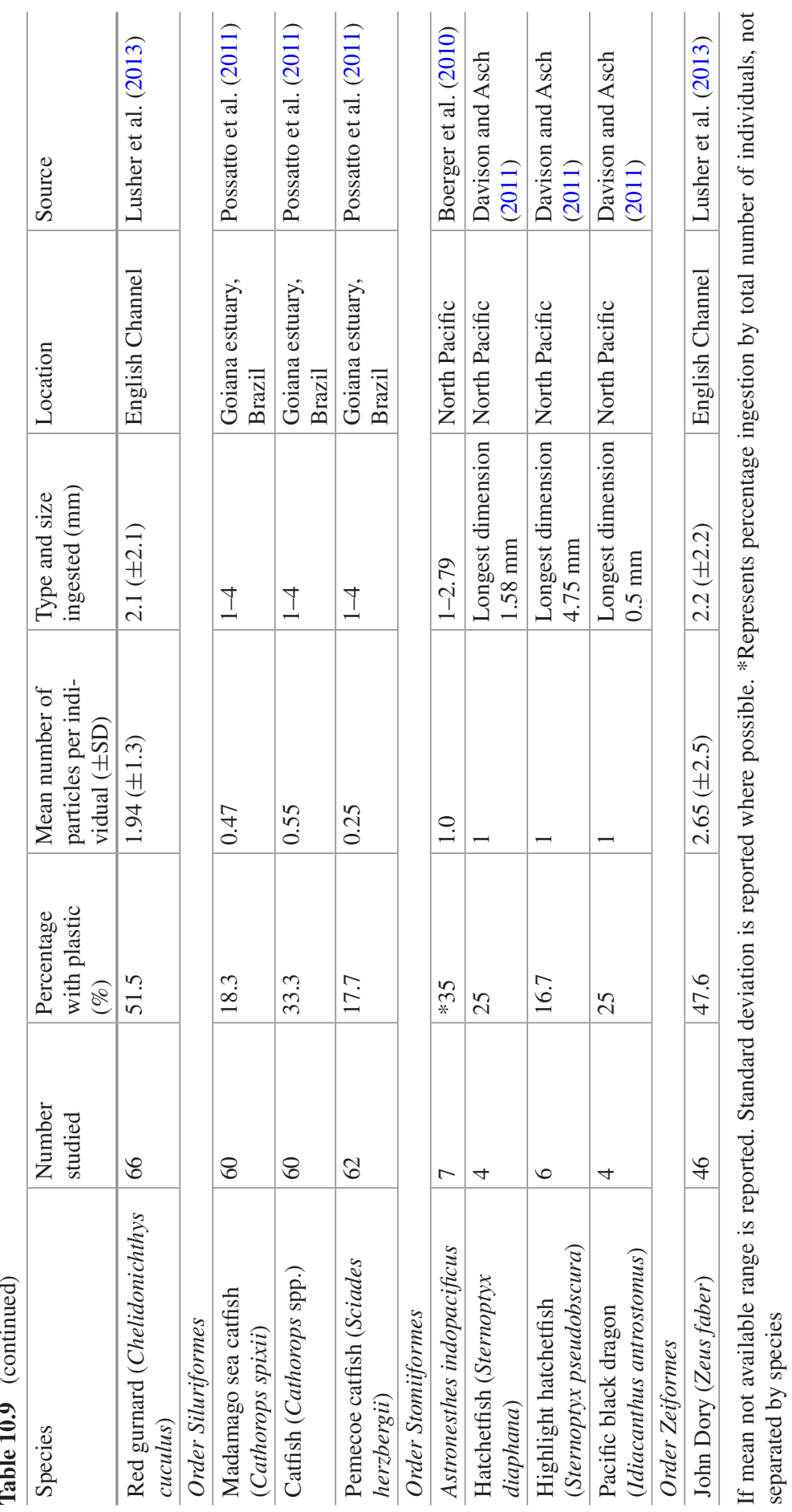


mortality rates were observed following a two-generation chronic toxicity test (12.5 $\mu \mathrm{g} \mathrm{mL}^{-1}$ ) (Lee et al. 2013). Although a third of gooseneck barnacle (Lepas spp.) stomachs examined contained microplastics, no adverse effect was reported for these filter feeders (Goldstein and Goodwin 2013). Interestingly, the stomachs of mass stranded Humboldt squids (Dosidicus gigas) contained plastic pellets (Braid et al. 2012). This large predatory cephalopod usually feeds at depth between 200 and $700 \mathrm{~m}$. The route of uptake is unclear; the squid may have fed directly on sunken pellets, or on organisms with pellets in their digestive system.

\subsubsection{Benthic Invertebrates}

A number of benthic invertebrates have been studied under laboratory conditions to investigate the consequences of microplastic ingestion (Table 10.8). Laboratory feeding and retention trials have focused on direct exposure of invertebrates to microplastic particles (as summarised by Cole et al. 2011; Wright et al. 2013a). Exposure studies demonstrated that benthic invertebrates including lugworms (Arenicola marina), amphipods (Orchestia gammarellus) and blue mussels (Mytilus edulis) feed directly on microplastics (Thompson et al. 2004; Wegner et al. 2012), and deposit-feeding sea cucumbers even selectively ingested microplastic particles (Graham and Thompson 2009).

Although microplastic uptake was recorded for a number of species, organisms appear to reject microplastics before digestion and excrete microplastics after digestion. Pseudofaeces production is a form of rejection before digestion but requires additional energetic cost. Furthermore, prolonged pseudofaeces production could lead to starvation (Wegner et al. 2012). On the other hand, polychaete worms, sea cucumbers and sea urchins are able to excrete unwanted materials through their intestinal tract without suffering obvious harm (Thompson et al. 2004; Graham and Thompson 2009; Kaposi et al. 2014). Adverse effects of microplastic ingestion were reported for lugworms: weight loss was positively correlated with concentration of spiked sediments (40-1300 $\mu \mathrm{m}$ polystyrene) (Besseling et al. 2013). Similarly, Wright et al. (2013b) recorded significantly reduced feeding activity and significantly decreased energy reserves in lugworm exposed to $5 \%$ un-plasticised polyvinyl chloride (U-PVC). Supressed feeding reduced energy assimilation, compromising fitness. At the chronic exposure level, either fewer particles were ingested overall or a lack of protein coating on the U-PVC may have weakened particle adhesion to the worm's feeding apparatus.

Several studies have raised concern for microplastic retention and transference between organisms' tissues. For example, microplastics were retained in the digestive tract of mussels, and transferred to the haemolymph system after three days (Browne et al. 2008). However, negative effects on individuals were not detected. Von Moos et al. (2012) tracked particles of high density polyethylene (HDPE) into the lysosomal system of mussels after three hours of exposure; particles were taken up by the gills and transferred to the digestive tract and lysosomal system, again triggering an inflammatory immune response. It should be 
noted, however, that while these studies succeeded in determining the pathways of microplastics in organisms the exposure concentrations used to achieve this goal exceeded those expected in the field, such that the results have to be treated with care.

Studies of microplastic ingestion by benthic invertebrates in the field are less common than laboratory studies. Murray and Cowie (2011) identified fibres of monofilament plastics that could be sourced to fibres of trawls and fragments of plastic bags in the intestines of the commercially valuable Norway lobster (Nephrops norvegicus). These results indicated that normal digestive processes do not eliminate some of the filaments as they cannot pass through the gastric mill system. Norway lobsters have various feeding modes, including scavenging and predation, and are not adapted to cut flexible filamentous materials (Murray and Cowie 2011). The identification of microplastics in organisms that are caught for commercial purposes and subsequently consumed whole (including guts) highlights the potential human health implications. For example, field-caught brown shrimps (Crangon crangon) (Pott 2014) and farmed and store-brought bivalves (De Witte et al. 2014; Van Cauwenberghe and Janssen 2014) had microplastics in their digestive system.

Invertebrates could be used as indicator species for environmental contamination. Species such as Nephrops are able to integrate seasonal variation in microplastic abundance, providing an accurate measure of environmental contamination (Welden, pers. comm.). Additional studies are required to understand the flux of microplastic within benthic sediments and the interaction between different species of benthic infauna feeding in/or manipulating the sediment, such as bivalves and worms. Benthic infauna could ingest and/or excrete microplastics, the individuals or their faecal pellets may in turn be ingested by secondary consumers, thus affecting higher trophic levels.

\subsubsection{Fish}

Some of the earliest studies noting ingestion of microplastics by wild-caught fish include coastal species from the USA (Carpenter et al. 1972) and the U.K. (Kartar et al. 1973, 1976). More recent studies from the NPCG reported microplastic (fibres, fragments and films) ingestion by mesopelagic fish (Boerger et al. 2010; Davison and Asch 2011; Choy and Drazen 2013). Estuarine environments and their inhabitants are also prone to plastic contamination, which is hardly surprising given the riverine input (e.g. Morritt et al. 2014). Estuarine fish affected include catfish, Ariidae, (23\% of individuals examined) and estuarine drums, Scianenidae, (7.9\% of individuals examined), which spend their entire life cycle in estuaries (Possatto et al. 2011; Dantas et al. 2012). Similarly, $13.4 \%$ of bottom-feeding fish (Gerreidae) from a tropical estuary in northeast Brazil contained microplastics in their stomachs (Ramos et al. 2012). The authors suggested that ingestion occurred during suction feeding on biofilms. 
Lusher et al. (2013) reported microplastic polymers from 10 fish species from the English Channel. Of the 504 fish examined, $37 \%$ had ingested a variety of microplastics, the most common being polyamide and the semi-synthetic material rayon. Similarly, Boerger et al. (2010) recorded microplastics in $35 \%$ planktivorous fish examined from the NPCG ( $94 \%$ of which were plastic fragments). Fish from the northern North Sea ingested microplastics at significantly lower levels (1.2\%) compared to those from the southern North Sea $(5.4 \%)$ (Foekema et al. 2013). All the studies cited suggest direct ingestion as the prime route of exposure, either targeted as food or mistaken for prey items. No adverse effects of ingestion were reported. Consequently, studies are required to follow the route of microplastic ingestion in fish, to assess if microplastics are egested in faecal pellets as seen in invertebrates. Dos Santos and Jobling (1992) showed that microplastic beads ( $2 \mathrm{~mm})$ were excreted quickly following ingestion, whereas larger beads $(5 \mathrm{~mm})$ were held for prolonged periods of time. This implies that larger items of plastic might pose a greater risk following ingestion whereas smaller microplastics are likely to be excreted along with natural faeces.

\subsubsection{Sea Birds}

Numerous studies have dealt with the ingestion of marine debris by sea birds (see Kühn et al. 2015). Microplastics and small plastic items have been isolated from birds targeted deliberately for dietary studies, dead cadavers, regurgitated samples and faeces (Table 10.10). Nearly 50 species of Procellariiformes (fulmars, petrels, shearwaters, albatrosses), known to feed opportunistically at the sea surface had microplastics in their stomachs. Ingested microplastics appeared to comprise primarily of pellets and user-fragments (Ryan 1987; Robards et al. 1995) although there was a decrease in the proportion of pellets ingested by birds from the south Atlantic between the 1980s and 2006 (Ryan 2008). This trend is also true for shorttailed shearwater (Puffinus tenuirostris) from the North Sea (Vlietstra and Parga 2002). In this case however, the mass of industrial plastics (pellets) have decreased by half and the mass of plastic fragments has tripled (van Franeker et al. 2011). It is possible that the shift in the type of plastic consumed may be explained by fragmentation of larger user-plastics into smaller microplastics, the accumulation of user-plastic over time and a decreased disposal of industrial plastics (Thompson et al. 2004), or simply by a stronger awareness of the presence of microplastics.

Seabirds appear to be able to remove microplastics from their digestive tracts as regurgitation has been observed in the boluses of glaucous-winged gulls (Larus glaucescens) (Lindborg et al. 2012). However, this suggests that parents expose their offspring to plastics during feeding. Juveniles of northern fulmars (Fulmarus glacialis) had more plastic in their intestines than adults (Kühn and van Franeker 2012), with higher quantities in areas of higher fishing and shipping traffic (van Franeker et al. 2011). Still, as the majority of birds examined did not die as a direct result of microplastic uptake, it can be concluded that microplastic ingestion 
does not affect seabirds as severely as macroplastic ingestion. To date, there have been no studies demonstrating nanometre-sized microplastics in sea birds. This could be because it is extremely difficult to control laboratory conditions in terms of contamination.

\subsubsection{Marine Mammals}

Only one study on microplastic ingestion by marine mammals has been published to date. Bravo Rebolledo et al. (2013) recorded microplastics in stomachs (11\%, $\mathrm{n}=100)$ and intestines $(1 \%, \mathrm{n}=107)$ of harbour seals (Phoca vitulina). Direct microplastic ingestion by other species of marine mammals has not been observed. However, larger plastics items were identified in the stomachs of numerous cetaceans (46\% of all species; Baulch and Perry 2014, see also Kühn et al. 2015). The frequency of microplastic uptake by marine mammals is hitherto unknown, but could occur through filter feeding, inhalation at the water-air interface, or via trophic transfer from prey items. As baleen whales (Mysticetes) strain water between baleen plates, to trap planktonic organisms and small fish (Nemoto 1970), they may incidentally trap microplastics. Thus, their feeding mode may render baleen whales more susceptible to direct microplastic ingestion than toothed (Odotocetes) or beaked whales (Ziphiids) which are active predators of squid and fish (Pauly et al. 1998). It is also likely that marine mammals are exposed to microplastic via trophic transfer from prey species. For example, microplastics were recorded from the scats of fur seals (Arctocephalus spp.) believed to originate from lantern fish (Electrona subaspera) (Eriksson and Burton 2003).

Cetaceans were suggested as sentinels for microplastic pollution (Fossi et al. 2012a; Galgani et al. 2014). However, it is notoriously difficult to extract and subsequently assess microplastics from cetacean stomachs, the often large size and decomposition rate of stomachs make sampling almost impossible. Furthermore, strandings are infrequent and unpredictable. Although adaption of sampling methods for smaller organisms such as fish and birds have the potential to be implemented, further work is necessary. The assessment of phthalate concentrations in the blubber of stranded fin whales (Balaenoptera physalus) (Fossi et al. 2012b, 2014) could serve as an indicator for the uptake of microplastics, but this raises other concerns as it is not possible to distinguish the origin of the phthalates. Exposure routes could be via micro- or macroplastics or simply from direct uptake of chemicals from the surrounding seawater into the blubber. Further work is essential to assess if microplastics significantly affect marine mammals.

\subsubsection{Sea Turtles}

Although all species of marine turtle ingest macroplastics (Derraik 2002; Schuyler et al. 2014; Kühn et al. 2015), only one study reported plastic pellets in the stomachs of the herbivorous green turtles (Chelonia mydas) (Tourinho et al. 2010). 


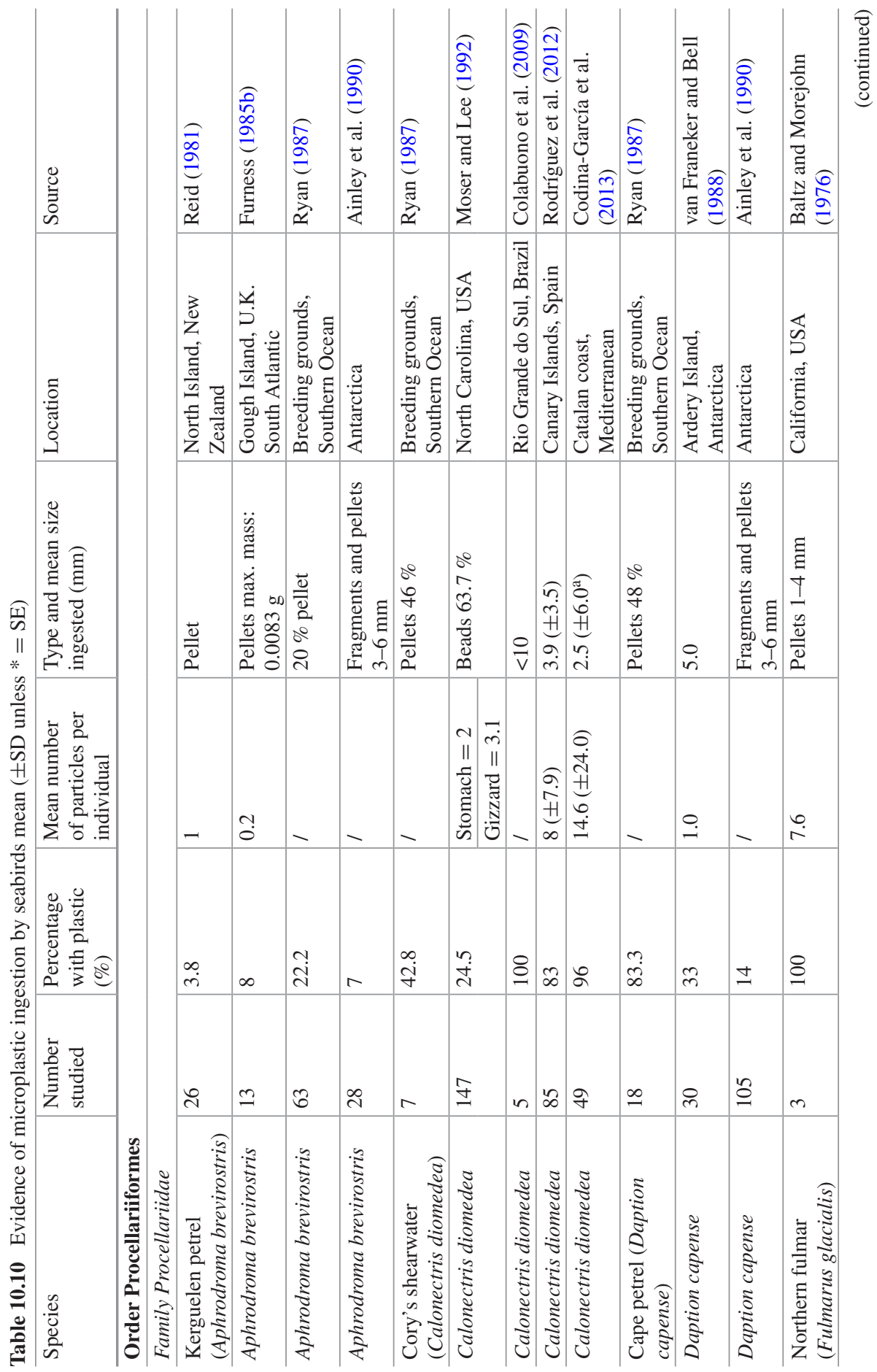


A. Lusher

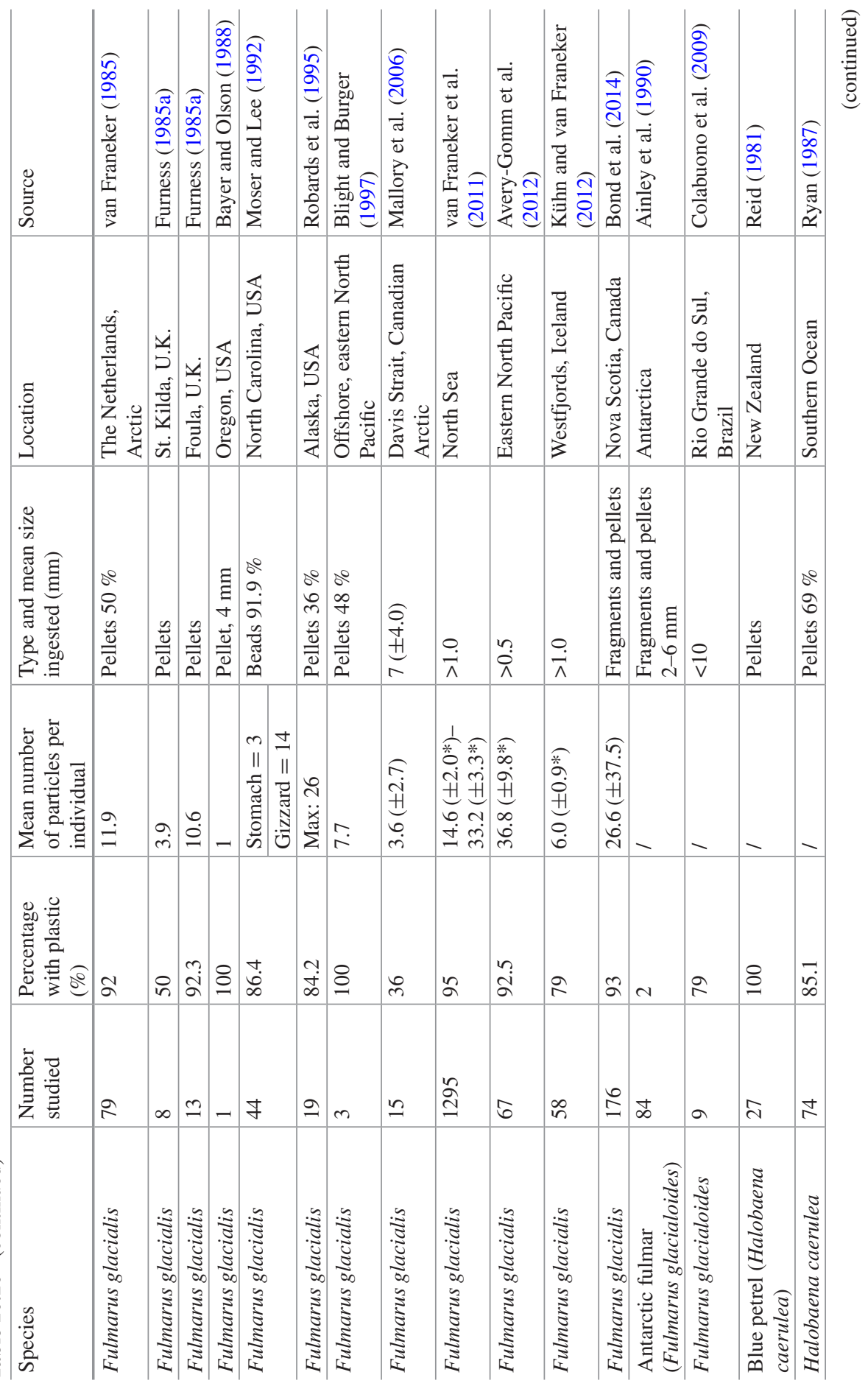




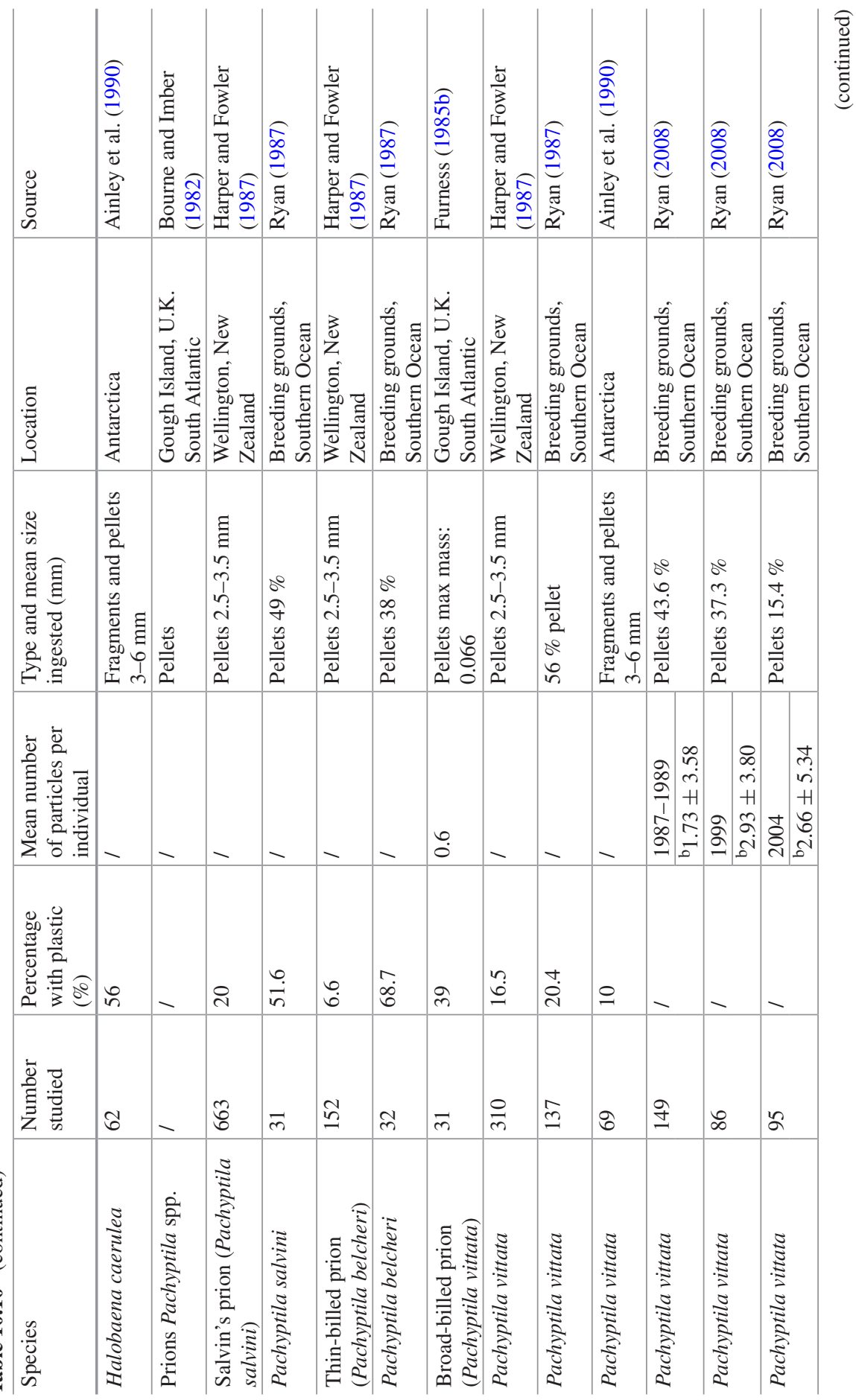


A. Lusher

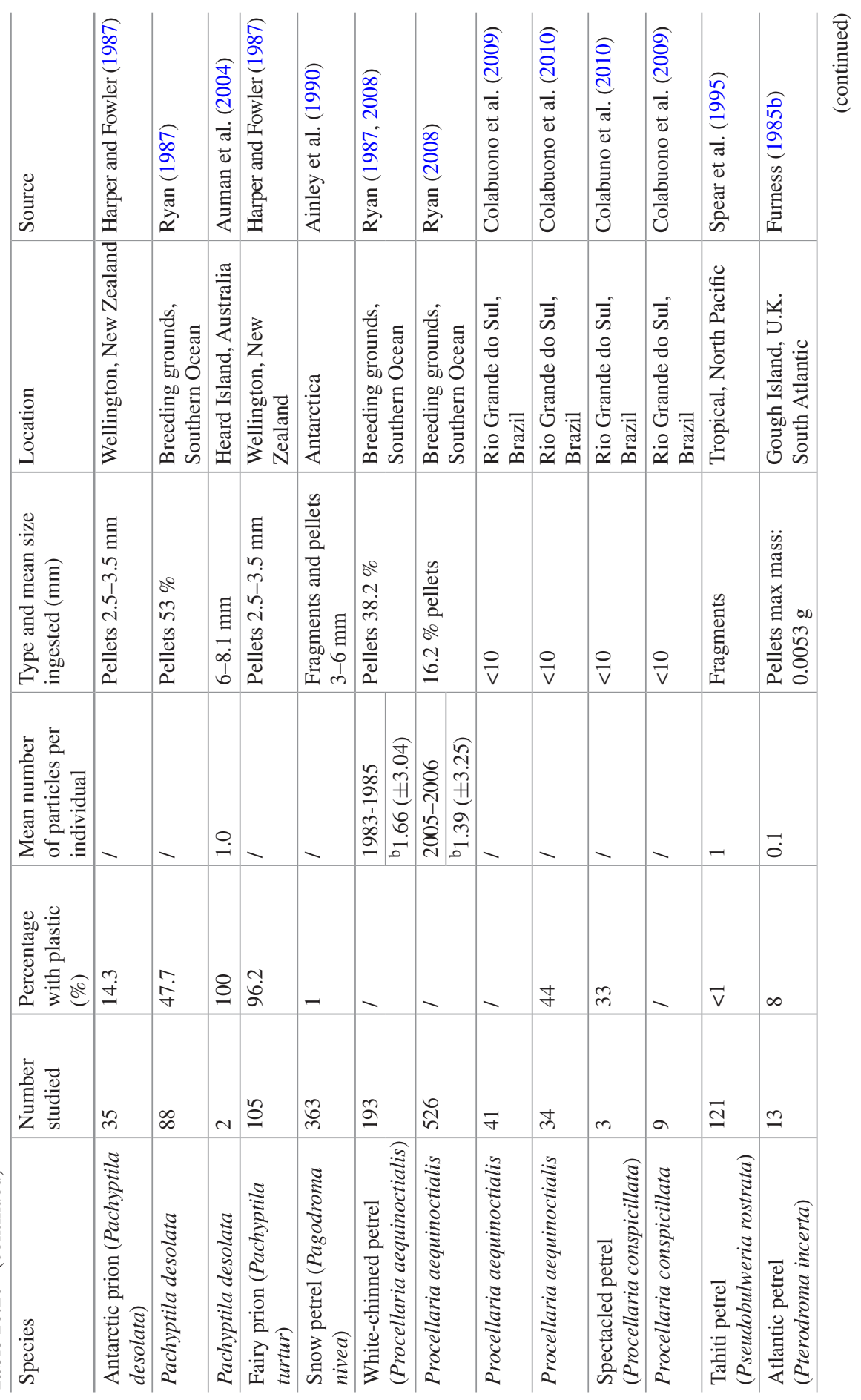




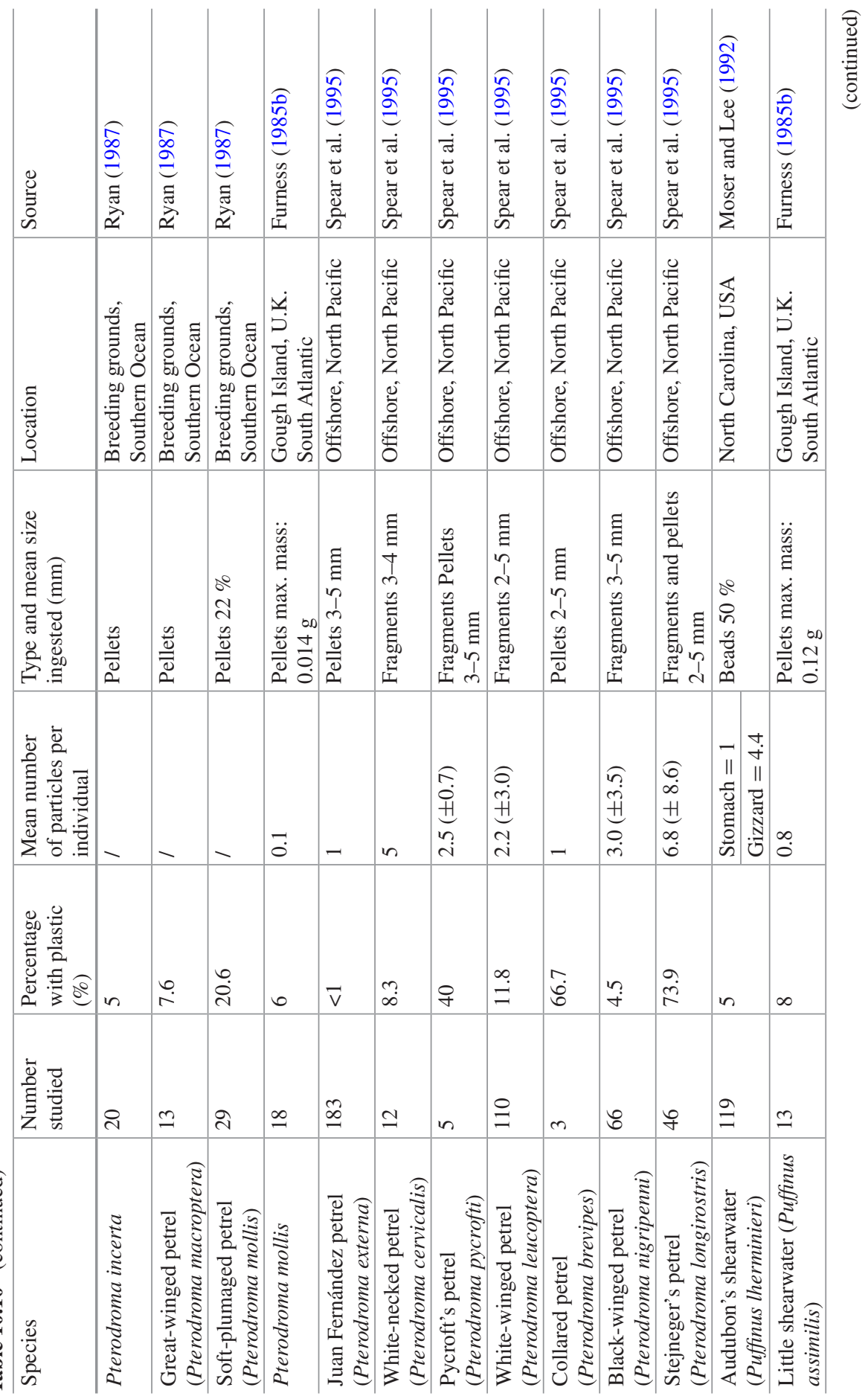


A. Lusher

\begin{tabular}{|c|c|c|c|c|c|c|c|c|c|c|c|c|c|c|}
\hline 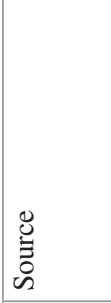 & 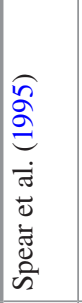 & 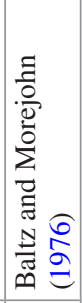 & 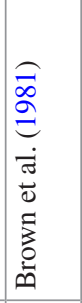 & 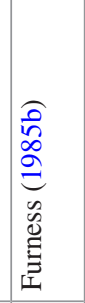 & 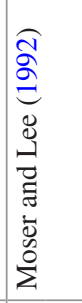 & 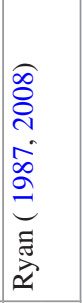 & 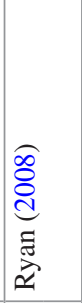 & 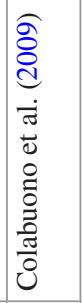 & 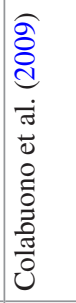 & 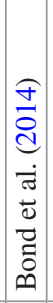 & 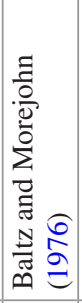 & 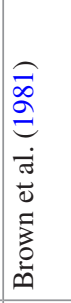 & 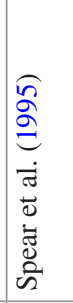 & $\begin{array}{l}\widehat{\sigma} \\
\stackrel{2}{\Xi} \\
-50 \\
0\end{array}$ \\
\hline 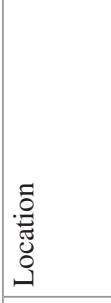 & 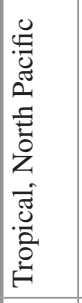 & 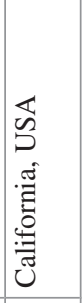 & 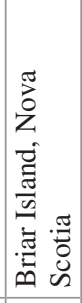 & 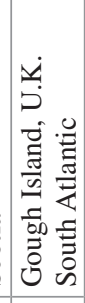 & 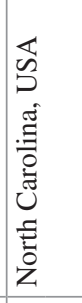 & 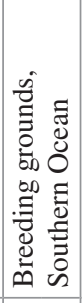 & 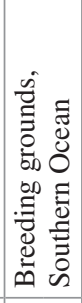 & 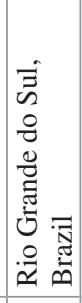 & 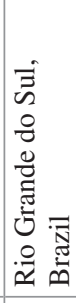 & 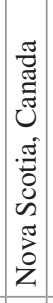 & 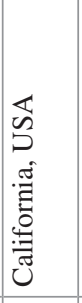 & 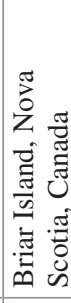 & 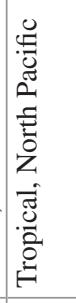 & 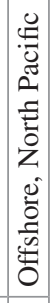 \\
\hline 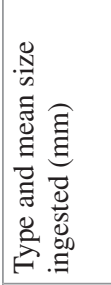 & 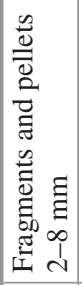 & 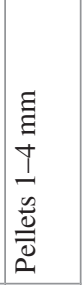 & 芯 & 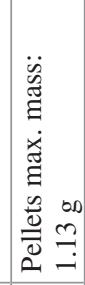 & 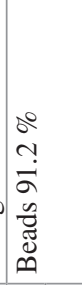 & 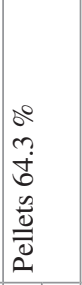 & $\begin{array}{l}00 \\
n \\
= \\
0 \\
\frac{0}{0} \\
0 \\
0\end{array}$ & $\begin{array}{l}\Xi \\
\vdots \\
\stackrel{\Xi}{\mathrm{v}} \\
\end{array}$ & 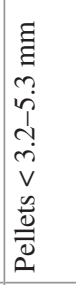 & 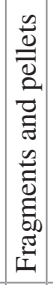 & $\begin{array}{l} \\
\Xi \\
\Xi \\
\pm \\
0 \\
0 \\
0 \\
0 \\
0\end{array}$ & 蒁 & 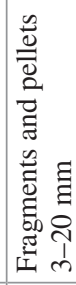 & 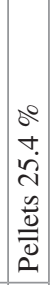 \\
\hline 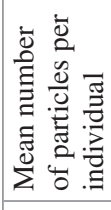 & $\begin{array}{l}0 \\
0 \\
\infty \\
H \\
n \\
\infty\end{array}$ & ָָ & - & $\stackrel{\sim}{\mathrm{I}}$ & 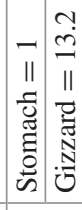 & 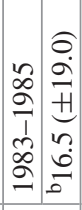 & 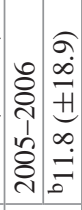 & - & - & $\begin{array}{l}\hat{\sigma} \\
\dot{\sigma} \\
\dot{H} \\
\infty \\
\stackrel{\Xi}{=}\end{array}$ & 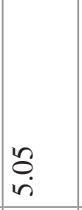 & - & 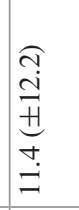 & - \\
\hline 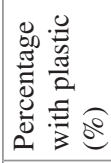 & 8 & ㄱ & 8 & 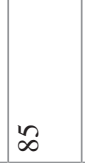 & $\begin{array}{l}0 \\
\text { రై }\end{array}$ & $\mathscr{8}$ & - & $\infty$ & 8 & $\infty$ & $\stackrel{\leftrightarrow}{\sim}$ & 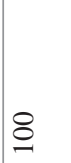 & $\begin{array}{l}m \\
\infty \\
i n\end{array}$ & $\begin{array}{l}n \\
\infty \\
\infty\end{array}$ \\
\hline 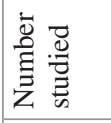 & $m$ & in & $\stackrel{\sim}{\sim}$ & 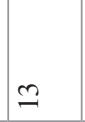 & $n$ & 으 & in & $\cong$ & 6 & ষ & $\vec{\sim}$ & in & ల) & $\frac{\infty}{\sim}$ \\
\hline 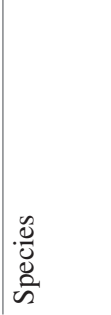 & 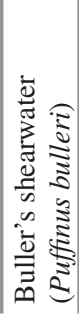 & 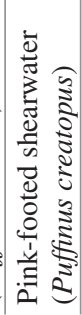 & 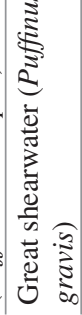 & 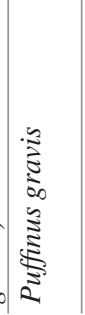 & 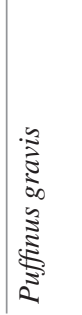 & 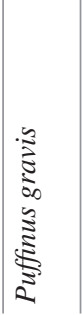 & 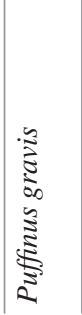 & 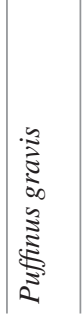 & 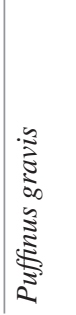 & 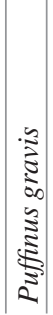 & 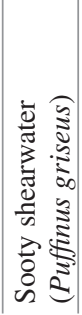 & 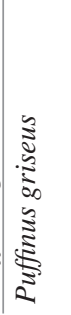 & 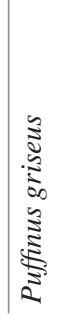 & 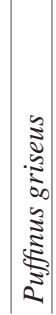 \\
\hline
\end{tabular}




\begin{tabular}{|c|c|c|c|c|c|c|c|c|c|c|c|c|c|c|c|c|}
\hline 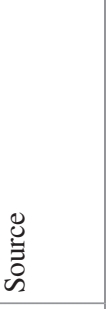 & 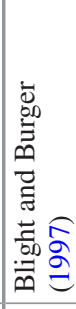 & 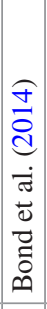 & 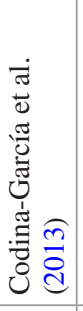 & 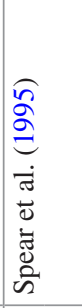 & 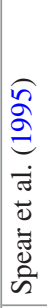 & & 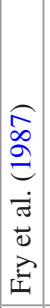 & 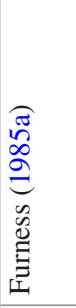 & 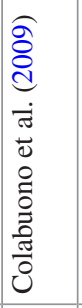 & 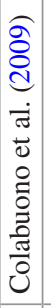 & 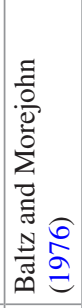 & $\begin{array}{l} \\
\widehat{\varrho} \\
2 \\
\stackrel{2}{0} \\
-50 \\
0\end{array}$ & 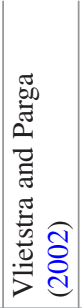 & 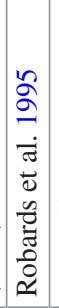 & 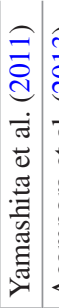 & 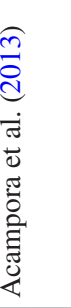 \\
\hline 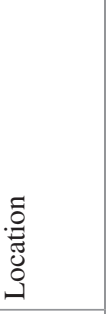 & 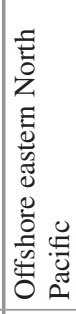 & 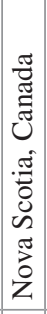 & 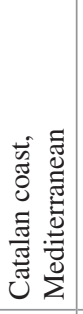 & 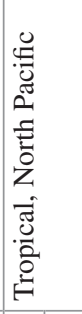 & 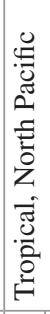 & & 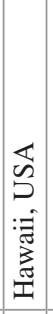 & 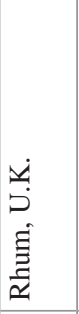 & 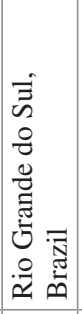 & 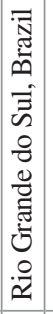 & 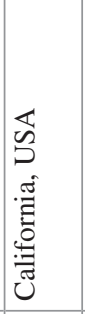 & 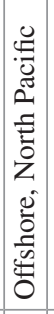 & 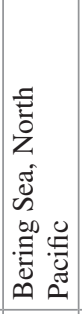 & 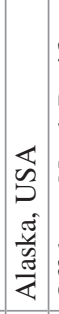 & 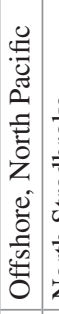 & 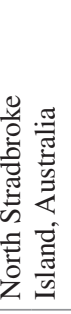 \\
\hline 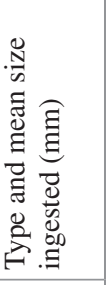 & 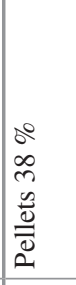 & 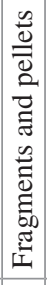 & 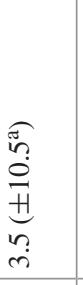 & 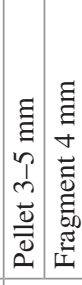 & 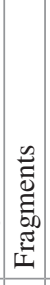 & 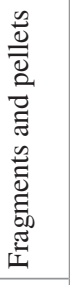 & 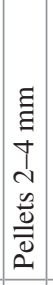 & $\frac{0}{0}$ & 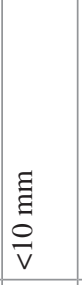 & 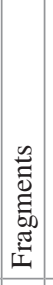 & 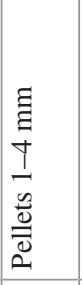 & $\begin{array}{l}0 \\
0 \\
n \\
6 \\
0 \\
0 \\
\frac{0}{0} \\
2 \\
\end{array}$ & 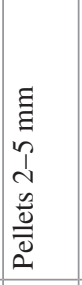 & 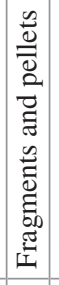 & 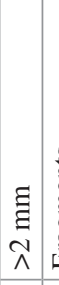 & 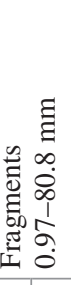 \\
\hline 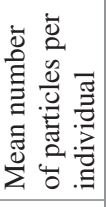 & मे. & 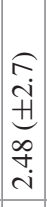 & 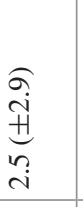 & - & 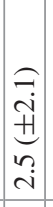 & 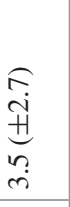 & $\begin{array}{l}= \\
\ddot{x} \\
\dot{\tilde{u}}\end{array}$ & $\stackrel{+}{\circ}$ & - & - & $\stackrel{\infty}{\infty}$ & - & 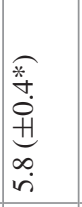 & - & 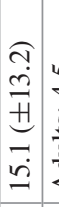 & 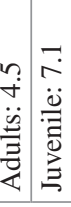 \\
\hline 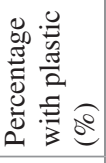 & $\approx$ & $\mathbb{N}$ & 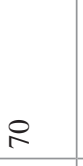 & 우 & $\nabla$ & $\stackrel{\sim}{\stackrel{\sim}{N}}$ & 8 & ஜ్లి & 8 & 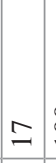 & 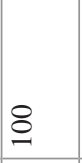 & $\begin{array}{l}\infty \\
\dot{\infty}\end{array}$ & ळे. & $\infty$ & $\Xi 1$ & $\widehat{6}$ \\
\hline 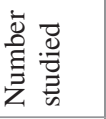 & ్ㅗ & in & ๖े & $n$ & $\vec{\imath}$ & $\widetilde{\sigma}$ & ¿े & 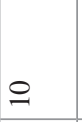 & $\sqrt[n]{2}$ & 0 & 0 & 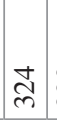 & లి & in & 2 & ఏે \\
\hline $\begin{array}{l}\frac{0}{8} \\
\text { के } \\
\text { के }\end{array}$ & 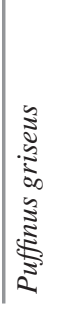 & 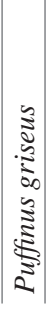 & 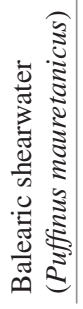 & 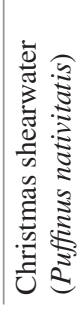 & 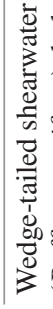 & 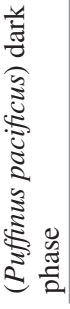 & 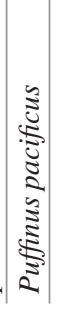 & 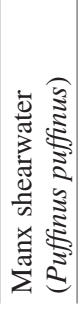 & 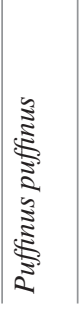 & 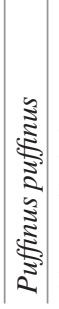 & 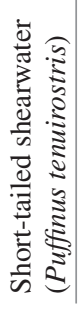 & $\mid$ & 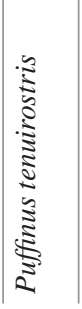 & 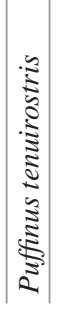 & 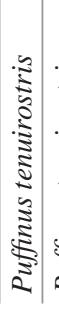 & 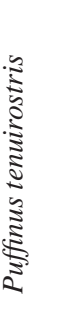 \\
\hline
\end{tabular}


A. Lusher

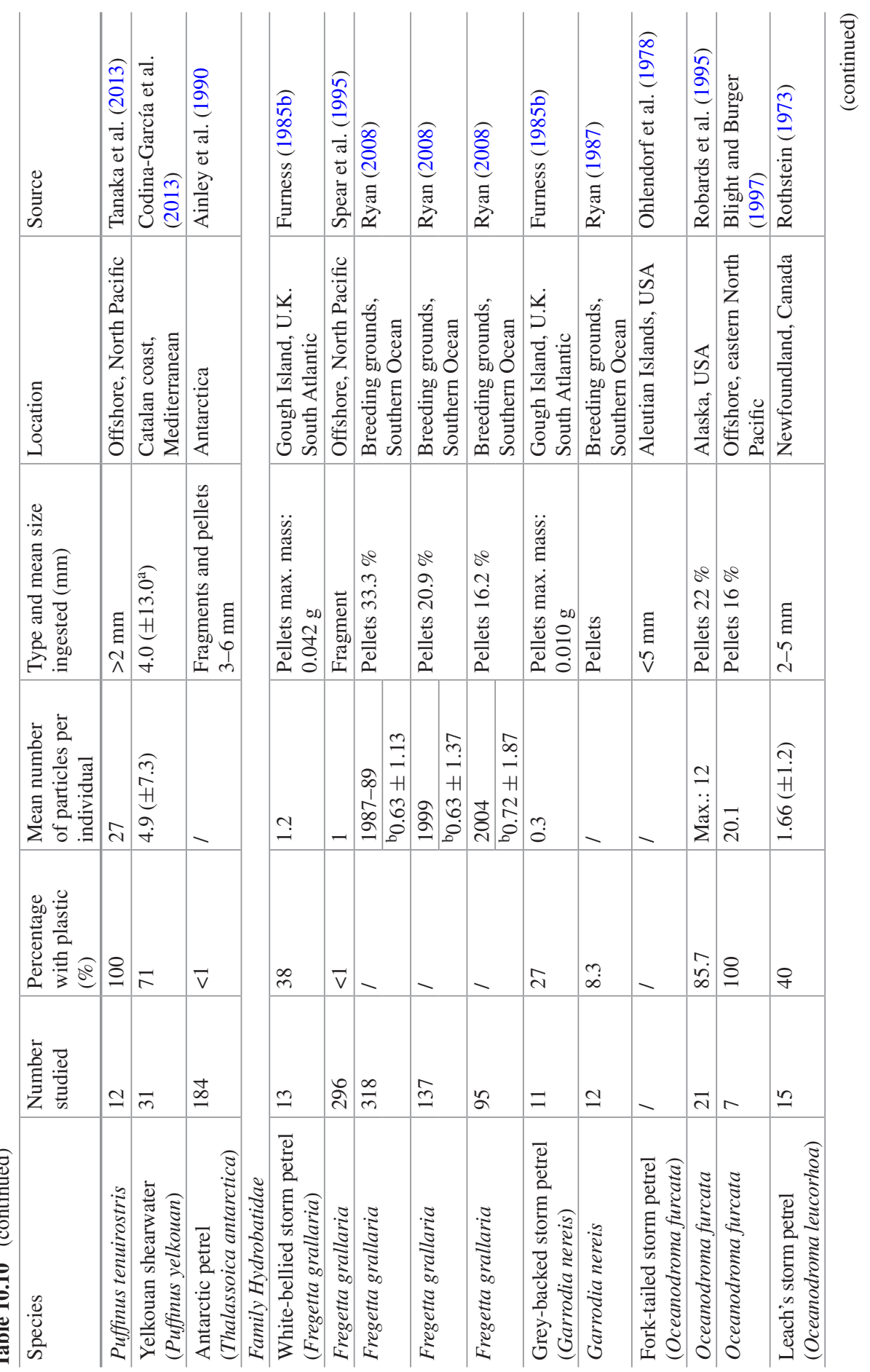




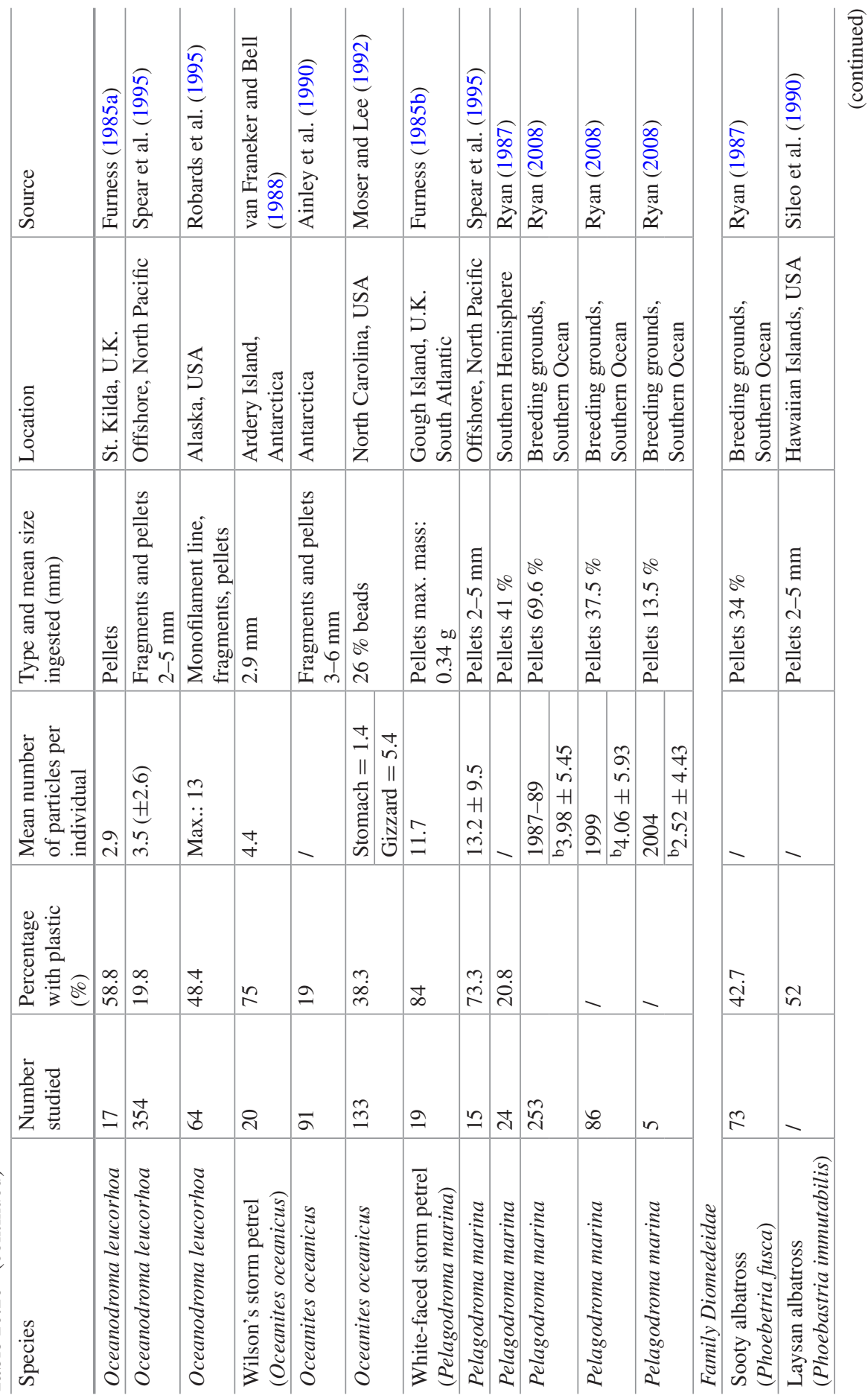


A. Lusher

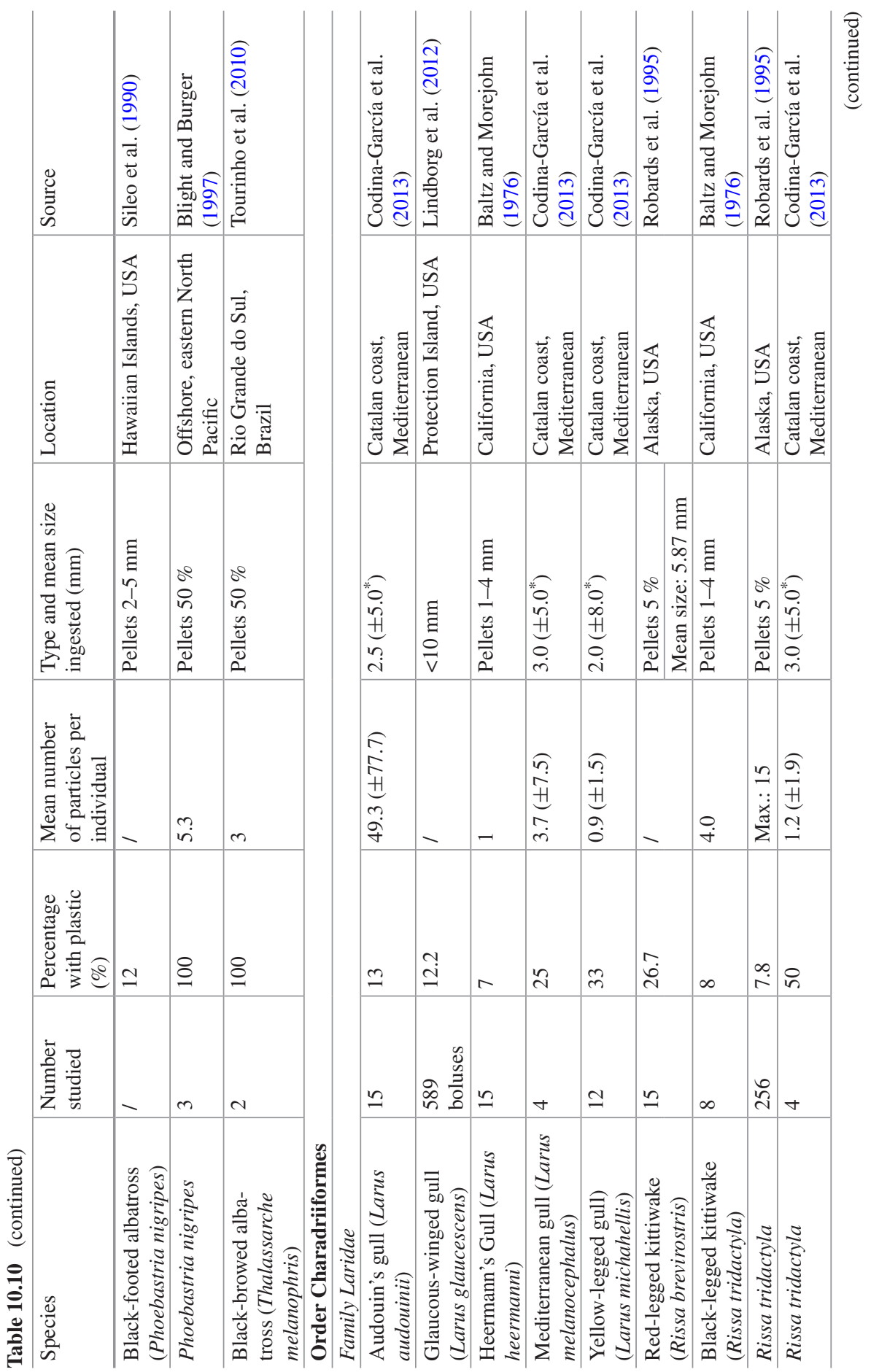




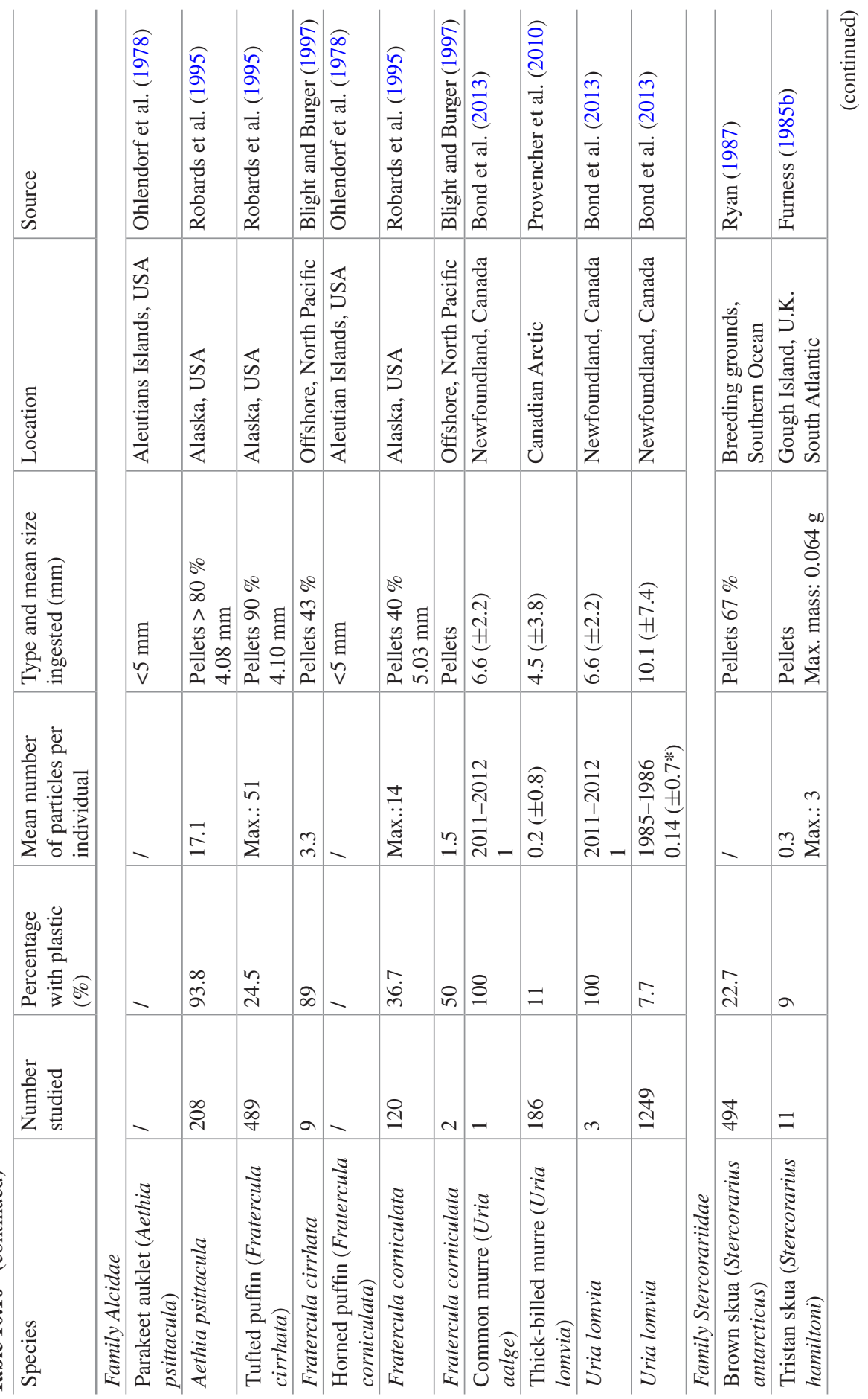


A. Lusher

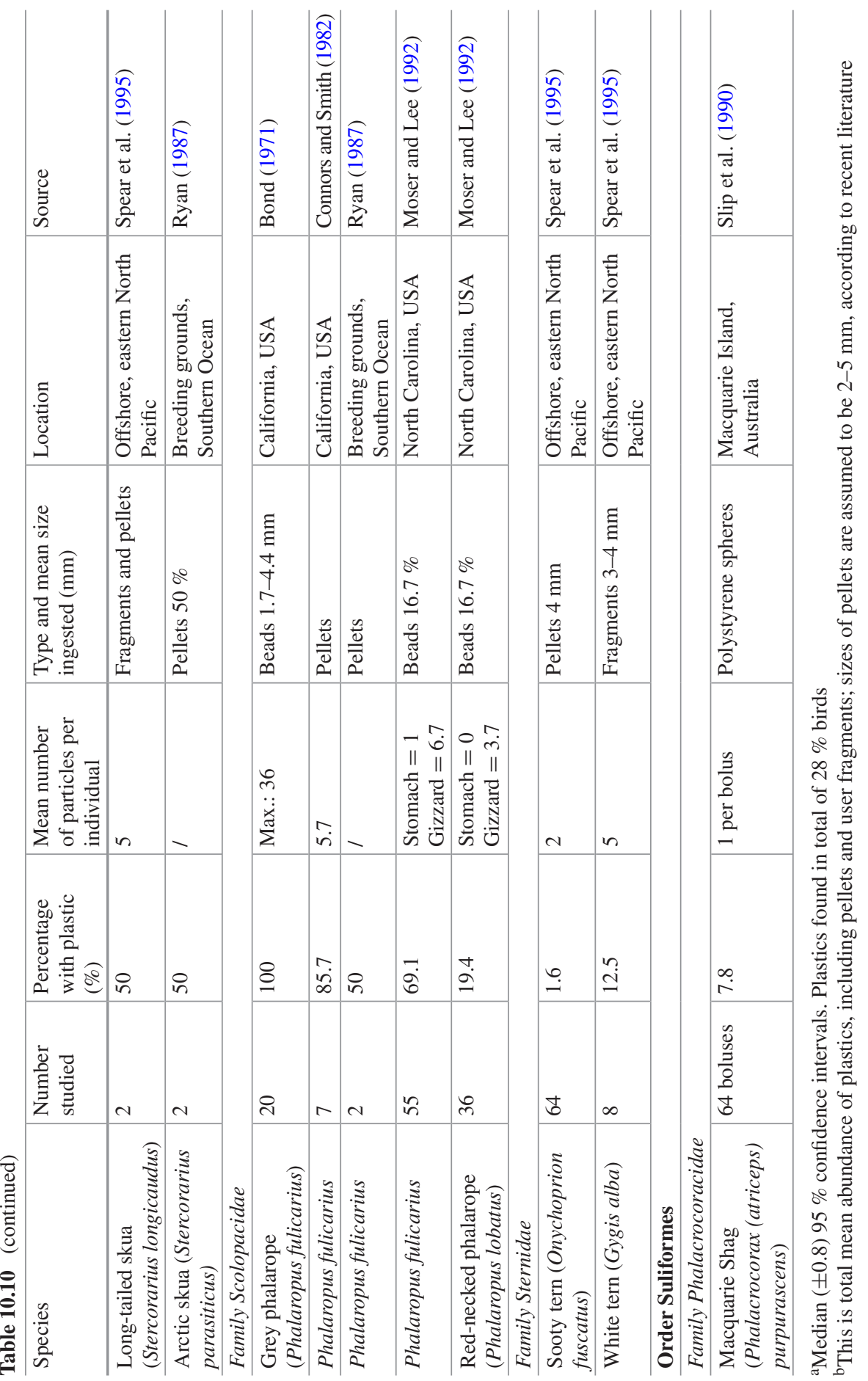


It is highly likely that other species of sea turtle also ingest microplastics incidentally or directly, depending on their feeding habits (Schuyler et al. 2014). Neonatal and oceanic post-hatchlings are generalist feeders (Bjorndal 1997), targeting plankton from surface waters and microplastic uptake may occur. Trophic transfer from prey items could be a pathway to larger individuals; loggerhead (Caretta caretta) and Kemp's Ridley (Lepidochelys kempii) turtles are carnivores, feeding on crustaceans and bivalves (Bjorndal 1997), which ingest microplastics (e.g. Browne et al. 2008). Flatbacks (Natator depressa) are also carnivores but feed on soft bodied invertebrates (Bjorndal 1997), including sea cucumbers, which again, ingest microplastics (Graham and Thompson 2009). Leatherbacks (Dermochelys coriacea) feed on gelatinous organisms (Bjorndal 1997) and are thus more likely to ingest macroplastics because of their size and similarity to prey items. If microplastics are ingested they could affect sea turtle growth and development if they are not egested. Additional work is required to understand whether turtles actively ingest microplastics, and if so, the extent of the harm caused.

\subsubsection{Trophic Transfer}

Absorption and ingestion of microplastics by organisms from the primary trophic level, e.g. phytoplankton and zooplankton, could be a pathway into the food chain (Bhattacharya et al. 2010). Many species of zooplankton undergo a diurnal migration. Migrating zooplankton could be considered a vector of microplastic contamination to greater depths of the water column and its inhabitants, either through predation or the production of faecal pellets sinking to the seafloor (Wright et al. 2013a). Only a few studies deal with the potential for microplastics to be transferred between trophic levels following ingestion. Field observation highlighted the presence of microplastics in the scat of fur seals (Arctocephalus spp.) and Eriksson and Burton (2003) suggested that microplastics had initially been ingested by the fur seals' prey, the plankton feeding Mycophiids. In feeding experiments, Farrell and Nelson (2013) identified microplastic in the gut and haemolymph of the shore crab (Carcinus maenas), which had previously been ingested by blue mussels (Mytilus edulis). There was large variability in the number of microspheres in tissues samples, and the results have to be treated with caution as the number of individuals was low and the exposure levels used exceeded those from the field. Similarly, Nephrops-fed fish, which had been seeded with microplastic strands of polypropylene rope were found to ingest but not to excrete the strands (Murray and Cowie 2011), again implying potential trophic transfer. As mentioned above, microplastics were also detected in cod, whiting, haddock, bivalves and brown shrimp, which are consumed by humans and raises concerns about trophic transfer to humans and human exposure (see Galloway 2015). Further studies are required to increase our understanding of trophic transfer. 


\subsubsection{Microplastic Effect on Habitats}

Surfaces of buoyant microplastics provide habitats for rafting organisms. For example, pelagic insects (Halobates micans and H. sericeus) utilize microplastic pellets for oviposition (Goldstein et al. 2012; Majer et al. 2012). Indeed, Goldstein et al. (2012) attributed an overall increase in H. sericeus and egg densities in the NPCG to high concentrations of microplastics. Likewise, plastics serve as a floating habitat for bacterial colonisation (Lobelle and Cunliffe 2011). Microorganisms including Bacillus bacteria (mean: $1664 \pm 247$ individuals $\mathrm{mm}^{-2}$ ) and pennate diatoms (mean: $1097 \pm 154$ individuals $\mathrm{mm}^{-2}$ ) were identified on plastic items from the North Pacific gyre (Carson et al. 2013). These studies suggest that microplastics affect the distribution and dispersal of marine organisms and may represent vectors to alien invasion. Plastics colonised by pathogenic viruses or bacteria may spread the potential for disease, but there is currently no evidence to support this hypothesis.

Microplastic buried in sediments could have fundamental impacts on marine biota as they increase the permeability of sediment and decrease thermal diffusivity (Carson et al. 2011). This may affect temperature-dependent processes. For example, altered temperatures during incubation can bias the sex ratios of sea turtle eggs. At $30{ }^{\circ} \mathrm{C}$, equal numbers of males and female embryos develop, whereas at temperatures $<28{ }^{\circ} \mathrm{C}$ all embryos become male (Yntema and Mrosovsky 1982). With microplastics in sediments it will take longer to reach maximum temperatures because of its increased permeability. Therefore, eggs may require a longer incubation period, with more male hatchlings because of the insulating effect. Microplastic concentrations as low as 1.5 can decrease maximum temperatures by $0.75^{\circ} \mathrm{C}$ (Carson et al. 2011), which has important implications for sexual bias in sea turtles including loggerhead turtles (Caretta caretta) and hawksbill turtles (Eretmochelys imbricata) (Yntema and Mrosovsky 1982; Mrosovsky et al. 1992). Changes in the sediment temperatures could also affect infaunal organisms as it may affect enzymatic and other physiological processes, feeding and growth rates, locomotory speeds, reproduction and ultimately population dynamics. However, this remains speculative until further researched.

\subsubsection{Summary}

Microplastic ingestion has been documented for a range of marine vertebrates and invertebrates (Fig. 10.1). Interactions were recorded primarily during controlled laboratory studies, but results from field sampling of wild populations also indicate microplastic ingestion. In the case of some invertebrates, adverse physiological and biological effects were reported. The biological repercussions depend on to the size of microplastics with smaller sizes having greater effects on organisms at the cellular level. In the micrometre range, plastics are readily ingested and egested whereas 


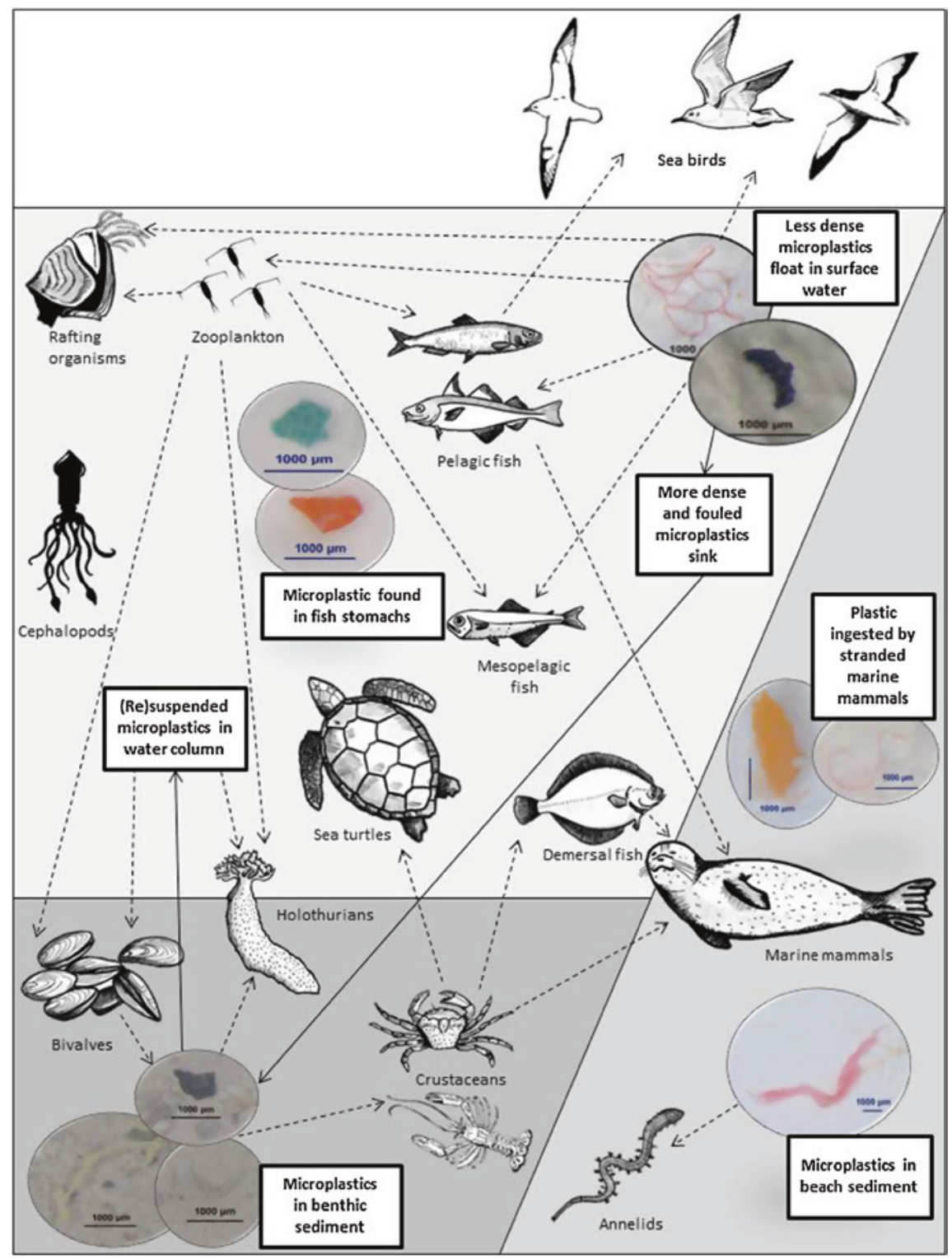

Fig. 10.1 Microplastic interactions in the marine environment including environmental links (solid arrows) and biological links (broken arrows), which highlights potential trophic transfer (Photos of microplastics: A. Lusher)

nanometre-sized plastics can pass through cell membranes. Acute exposure experiments demonstrated significant biological effects including weight loss, reduced feeding activity, increased phagocytic activity and transference to the lysosomal (storage) system. Larger microplastics $(2-5 \mathrm{~mm}$ ) may take longer to pass from the 
stomachs of organisms and could be retained in the digestive system, potentially increasing the exposure time to adsorbed toxins (see Rochman 2015).

It is important to determine the ecological effects of microplastic ingestion. Studies are required to assess the contamination of more species of fish, marine mammals and sea turtles, as well as consequences of microplastic uptake and retention. Further research is necessary to determine the limits of microplastic translocation between tissues, and assess the differences between multiple polymer types and shapes. It is likely that additional species of invertebrate ingest microplastics in wild populations, as fibres and fragments found in the field are actively selected in experiments. Although some organisms appear to be able to differentiate between microplastics and prey, and microplastic excretion has been recorded. Without knowledge of retention and egestion rates of field populations, it is difficult to deduce ecological consequences. There is some evidence to suggest that microplastics enter the food chain and transfer of microplastics between trophic levels implies bioaccumulation and biomagnification. Despite concerns raised by ingestion in the marine environment, the effects of microplastic ingestion in natural populations and the implications for food webs are not understood. Such knowledge is crucial in order to be able to develop and implement effective management strategies (Thompson et al. 2009). Additional studies are required to understand the flux of microplastic from benthic sediments to the infauna. Lastly, microplastics provide open ocean habitats for colonisation by invertebrates, bacteria and viruses. As a result, these organisms can be transported over large distances by ocean currents and/or through the water column (Kiessling et al. 2015).

\subsection{Conclusion}

Microplastics have been found in almost every marine habitat around the world, and plastic density along with ocean currents appears to have a significant effect on their distribution. Modelling studies suggest that floating debris accumulates in ocean gyres but this is dependent on the composition and shape of individual polymers. The widespread distribution and accumulation of microplastics raises concerns regarding the interaction and potential effects of microplastics on marine organisms. As microplastics interact with plankton and sediments, both suspension and deposit feeders may accidentally or selectively ingest microplastics. Despite concerns regarding ingestion, only a limited number of studies examined microplastic ingestion in the field. Knowledge of the retention rates of microplastics would enable estimations of the impacts of microplastic uptake. If rejection occurs before digestion, microplastics might pose less of a threat to organisms than initially assumed. However, there could be energetic costs associated with the production of pseudofaeces. Laboratory studies can be used to determine the end point of microplastic ingestion, and would benefit from using multiple types of microplastics to simulate field conditions. Unfortunately, it is difficult to establish a direct link between microplastics and adverse effects on marine biota 
experimentally. Furthermore, due to the difficult nature of field studies, it will be harder to understand effects on natural populations.

As microplastic research is still in its infancy, there are many more unanswered questions, the answers to which are required to build on current knowledge to develop a clearer picture of the impact of microplastics in the sea.

Acknowledgments The author would like to thank Emily Lorch, Julia Hemprich, Chelsea Rochman, Rick Officer and Ian O'Connor for their useful comments on an earlier draft. Bart Koelmans and an anonymous reviewer improved an earlier version of the manuscript. Marta Bolgan for the illustrations in Fig. 10.1. The author was awarded an Irish Research Council postgraduate scholarship [Project ID: GOIPG/2013/284] and a Galway-Mayo Institute of Technology 40th Anniversary studentship to conduct her Ph.D. research.

Open Access This chapter is distributed under the terms of the Creative Commons Attribution Noncommercial License, which permits any noncommercial use, distribution, and reproduction in any medium, provided the original author(s) and source are credited.

\section{References}

Acampora, H., Schuyler, Q. A., Townsend, K. A., \& Denise, B. (2013). Comparing plastic ingestion in juvenile and adult stranded short-tailed shearwaters (Puffinus tenuirostris) in eastern Australia. Marine Pollution Bulletin, 78, 63-68.

Ainley, D. G., Fraser, W. R. \& Spear, L. B. (1990). The incidence of plastic in the diets of Antarctic Seabirds. In Proceedings of the Second International Conference on Marine Debris (pp. 682-691). Honolulu, Hawaii, 2-7 April 1989.

Andrady, A. L., \& Neal, M. A. (2009). Applications and societal benefits of plastics. Philosophical Transactions of the Royal Society of London B, 364(1526), 1977-1984.

Antunes, J. C., Frias, J. G. L., Micaelo, A. C., \& Sobral, P. (2013). Resin pellets from beaches of the Portuguese coast and adsorbed persistent organic pollutants. Estuarine, Coastal and Shelf Science, 130, 62-69.

Arthur, C., Baker, J. \& Bamford, H. (2009). In Proceedings of the International Research Workshop on the Occurrence, Effects and Fate of Microplastic Marine Debris, NOAA Technical Memorandum NOS-OR \& R-30.NOAA (p. 530). Silver Spring, September 9-11, 2008.

Ashton, K., Holmes, L., \& Turner, A. (2010). Association of metals with plastic production pellets in the marine environment. Marine Pollution Bulletin, 60(11), 2050-2055.

Auman, H. J., Woehler, E. J., Riddle, M. J., \& Burton, H. (2004). First evidence of ingestion of plastic debris by seabirds at sub-Antarctic Heard Island. Marine Ornithology, 32(1), $105-106$.

Austin, H. M., \& Stoops-Glass, P. M. (1977). The distribution of polystyrene spheres and nibs in Block Island Sound during 1972-1973. Chesapeake Science, 18, 89-91.

Avery-Gomm, S., O'Hara, P. D., Kleine, L., Bowes, V., Wilson, L. K., \& Barry, K. L. (2012). Northern fulmars as biological monitors of trends of plastic pollution in the eastern North Pacific. Marine Pollution Bulletin, 64(9), 1776-1781.

Ballent, A., Pando, S., Purser, A., Juliano, M. F., \& Thomsen, L. (2013). Modelled transport of benthic marine microplastic pollution in the Nazaré Canyon. Biogeosciences, 10(12), 7957-7970.

Baltz, D. M., \& Morejohn, G. V. (1976). Evidence from seabirds of plastic particle pollution off central California. Western Birds, 7(3), 111-112. 
Barnes, D. K. A., Galgani, F., Thompson, R. C., \& Barlaz, M. (2009). Accumulation and fragmentation of plastic debris in global environments. Philosophical Transactions of the Royal Society of London B, 364(1526), 1985-1998.

Barnes, D. K. A., Walters, A., \& Gonçalves, L. (2010). Macroplastics at sea around Antarctica. Marine Environmental Research, 70(2), 250-252.

Bayer, R. D., \& Olson, R. E. (1988). Plastic particles in 3 Oregon fulmars. Oregon Birds, 14, $155-156$.

Baulch, S., \& Perry, C. (2014). Evaluating the impacts of marine debris on cetaceans. Marine Pollution Bulletin, 80(1), 210-221.

Baztan, J., Carrasco, A., Chouinard, O., Cleaud, M., Gabaldon, J. E., Huck, T., et al. (2014). Protected areas in the Atlantic facing the hazards of micro-plastic pollution: First diagnosis of three islands in the Canary Current. Marine Pollution Bulletin, 80(1-2), 302-311.

Bergmann, M., \& Klages, M. (2012). Increase of litter at the Arctic deep-sea observatory HAUSGARTEN. Marine Pollution Bulletin, 64(12), 2734-2741.

Besseling, E., Wegner, A., Foekema, E. M., van den Heuvel-Greve, M. J., \& Koelmans, A. A. (2013). Effects of microplastic on fitness and PCB bioaccumulation by the Lugworm Arenicola marina (L.). Environmental Science \& Technology, 47, 593-600.

Bhattacharya, P., Turner, J. P., \& Ke, P.-C. (2010). Physical adsorption of charged plastic nanoparticles affects algal photosynthesis. The Journal of Physical Chemistry C, 114(39), $16556-16561$.

Bjorndal, K. A. (1997). Foraging ecology and nutrition of sea turtles. In P. L. Lutz \& J. A. Musick (Eds.), The biology of sea turtles (pp. 199-231). Boca Raton, Florida: CRC Press.

Blight, L. K., \& Burger, A. E. (1997). Occurrence of plastic particles in sea-birds from the eastern North Pacific. Marine Pollution Bulletin, 34(5), 323-325.

Boerger, C. M., Lattin, G. L., Moore, S. L., \& Moore, C. J. (2010). Plastic ingestion by planktivorous fishes in the North Pacific Central Gyre. Marine Pollution Bulletin, 60(12), 2275-2278.

Bolton, T. F., \& Havenhand, J. N. (1998). Physiological versus viscosity-induced effects of an acute reduction in water temperature on microsphere ingestion by trochophore larvae of the serpulid polychaete Galeolaria caespitosa. Journal of Plankton Research, 20(11), 2153-2164.

Bond, S. I. (1971). Red phalarope mortality in Southern California. Western Birds, 2(3), 97.

Bond, A. L., Provencher, J. F., Elliot, R. D., Ryan, P. C., Rowe, S., Jones, I. L., et al. (2013). Ingestion of plastic marine debris by common and thick-billed Murres in the northwestern Atlantic from 1985 to 2012. Marine Pollution Bulletin, 77(1), 192-195.

Bond, A. L., Provencher, J. F., Daoust, P. Y. \& Lucas, Z. N. (2014). Plastic ingestion by fulmars and shearwaters at Sable Island, Nova Scotia, Canada. Marine Pollution Bulletin, 87(1), 68-75.

Bourne, W. R. P., \& Imber, M. J. (1982). Plastic pellets collected by a prion on Gough Island, central South Atlantic Ocean. Marine Pollution Bulletin, 13(1), 20-21.

Braid, H. E., Deeds, J., DeGrasse, S. L., Wilson, J. J., Osborne, J., \& Hanner, R. H. (2012). Preying on commercial fisheries and accumulating paralytic shellfish toxins: a dietary analysis of invasive Dosidicus gigas (Cephalopoda Ommastrephidae) stranded in Pacific Canada. Marine Biology, 159(1), 25-31.

Bravo Rebolledo, E. L., van Franeker, J. A., Jansen, O. E., \& Brasseur, S. M. (2013). Plastic ingestion by harbour seals (Phoca vitulina) in The Netherlands. Marine Pollution Bulletin, 67(1), 200-202.

Brilliant, M. G. S., \& MacDonald, B. A. (2000). Postingestive selection in the sea scallop Placopecten magellanicus (Gmelin): The role of particle size and density. Journal of Experimental Marine Biology and Ecology, 253, 211-227.

Brilliant, M. G. S., \& MacDonald, B. A. (2002). Postingestive selection in the sea scallop (Placopecten magellanicus) on the basis of chemical properties of particles. Marine Biology, 141, 457-465.

Brown, R. G. B., Barker, S. P., Gaskin, D. E., \& Sandeman, M. R. (1981). The foods of great and sooty shearwaters Puffinus gravis and P. griseus in eastern Canadian waters. Ibis, 123(1), 19-30. 
Browne, M. A. (2015). Sources and pathways of microplastic to habitats. In M. Bergmann, L. Gutow, \& M. Klages (Eds.), Marine anthropogenic litter (pp. 229-244). Springer, Berlin.

Browne, M. A., Dissanayake, A., Galloway, T. S., Lowe, D. M., \& Thompson, R. C. (2008). Ingested microscopic plastic translocates to the circulatory system of the mussel, Mytilus edulis (L.). Environmental Science \& Technology, 42(13), 5026-5031.

Browne, M. A., Galloway, T. S., \& Thompson, R. C. (2010). Spatial patterns of plastic debris along estuarine shorelines. Environmental Science \& Technology, 44(9), 3404-3409.

Browne, M. A., Crump, P., Niven, S. J., Teuten, E., Tonkin, A., Galloway, T., et al. (2011). Accumulation of microplastic on shorelines worldwide: Sources and sinks. Environmental Science \& Technology, 45(21), 9175-9179.

Browne, M. A., Niven, S. J., Galloway, T. S., Rowland, S. J., \& Thompson, R. C. (2013). Microplastic moves pollutants and additives to worms, reducing functions linked to health and biodiversity. Current Biology, 23(23), 2388-2392.

Carpenter, E. J., \& Smith, K. L. (1972). Plastics on the Sargasso Sea surface. Science, 175, 1240-1241.

Carpenter, E. J., Anderson, S. J., Harvey, G. R., Miklas, H. P., \& Peck, B. B. (1972). Polystyrene spherules in coastal waters. Science, 178, 749-750.

Carson, H. S., Colbert, S. L., Kaylor, M. J., \& McDermid, K. J. (2011). Small plastic debris changes water movement and heat transfer through beach sediments. Marine Pollution Bulletin, 62(8), 1708-1713.

Carson, H. S., Nerheim, M. S., Carroll, K. A., \& Eriksen, M. (2013). The plastic-associated microorganisms of the North Pacific Gyre. Marine Pollution Bulletin, 75(1), 126-132.

CBD (2012). Secretariat of the Convention on Biological Diversity and the Scientific and Technical Advisory Panel-GEF. Impacts of marine debris on biodiversity: Current status and potential solutions, Montreal, Technical Series No. 67, 61 pp.

Chua, E., Shimeta, J., Nugegoda, D., Morrison, P. D., \& Clarke, B. O. (2014). Assimilation of Polybrominated Diphenyl Ethers from microplastics by the marine amphipod, Allorchestes compressa. Environmental Science \& Technology, 48(14), 8127-8134.

Choy, C. A., \& Drazen, J. C. (2013). Plastic for dinner? Observations of frequent debris ingestion by pelagic predatory fishes from the central North Pacific. Marine Ecology Progress Series, $485,155-163$.

Christaki, U., Dolan, J. R., Pelegri, S., \& Rassoulzadegan, F. (1998). Consumption of picoplankton-size particles by marine ciliates: effects of physiological state of the ciliate and particle quality. Limnology and Oceanography, 43(3), 458-464.

Claessens, M., De Meester, S., Van Landuyt, L., De Clerck, K., \& Janssen, C. R. (2011). Occurrence and distribution of microplastics in marine sediments along the Belgian coast. Marine Pollution Bulletin, 62(10), 2199-2204.

Claessens, M., Van Cauwenberghe, L., Vandegehuchte, M. B., \& Janssen, C. R. (2013). New techniques for the detection of microplastics in sediments and field collected organisms. Marine Pollution Bulletin, 70, 227-233.

Codina-García, M., Militão, T., Moreno, J., \& González-Solís, J. (2013). Plastic debris in Mediterranean seabirds. Marine Pollution Bulletin, 77(1), 220-226.

Colabuono, F. I., Barquete, V., Domingues, B. S., \& Montone, R. C. (2009). Plastic ingestion by Procellariiformes in southern Brazil. Marine Pollution Bulletin, 58(1), 93-96.

Colabuono, F. I., Taniguchi, S., \& Montone, R. C. (2010). Polychlorinated biphenyls and organochlorine pesticides in plastics ingested by seabirds. Marine Pollution Bulletin, 60(4), 630-634.

Cole, M., Lindeque, P., Halsband, C., \& Galloway, T. S. (2011). Microplastics as contaminants in the marine environment: A review. Marine Pollution Bulletin, 62(12), 2588-2597.

Cole, M., Lindeque, P. K., Fileman, E. S., Halsband, C., Goodhead, R., Moger, J., et al. (2013). Microplastic ingestion by zooplankton. Environmental Science \& Technology, 47(12), 6646-6655.

Cole, M., Webb, H., Lindeque, P. K., Fileman, E. S., Halsband, C. \& Galloway, T. S. (2014a). Isolation of microplastics in biota-rich seawater samples and marine organisms. Scientific Reports, 4(4528). 
Cole, M., Lindeque, P. K., Fileman, E. S., Halsband, C. \& Galloway, T. S. (2014b). Impact of microplastics on feeding, function and decundity in the copepod Calanus helgolandicus. Platform presentation, International workshop on fate and impact of microplastics in marine ecosystems (MICRO2014). Plouzane (France), 13-15 January 2014.

Collignon, A., Hecq, J.-H., Glagani, F., Voisin, P., Collard, F., \& Goffart, A. (2012). Neustonic microplastic and zooplankton in the North Western Mediterranean Sea. Marine Pollution Bulletin, 64(4), 861-864.

Collignon, A., Hecq, J. H., Galgani, F., Collard, F., \& Goffart, A. (2014). Annual variation in neustonic micro-and meso-plastic particles and zooplankton in the Bay of Calvi (Mediterranean-Corsica). Marine Pollution Bulletin, 79(1-2), 293-298.

Colton, J. B., Burns, B. R., \& Knapp, F. D. (1974). Plastic particles in surface waters of the northwestern Atlantic. Science, 185(4150), 491-497.

Connors, P. G., \& Smith, K. G. (1982). Oceanic plastic particle pollution: suspected effect on fat deposition in red phalaropes. Marine Pollution Bulletin, 13(1), 18-20.

Cooper, D. A., \& Corcoran, P. L. (2010). Effects of mechanical and chemical processes on the degradation of plastic beach debris on the island of Kauai, Hawaii. Marine Pollution Bulletin, 60(5), 650-654.

Corcoran, P. L., Biesinger, M. C., \& Grifi, M. (2009). Plastics and beaches: A degrading relationship. Marine Pollution Bulletin, 58(1), 80-84.

Costa, M. F., Ivar, J. A., Christina, M., Ângela, B. A., Paula, S., Ivar do Sul, J. A., et al. (2010). On the importance of size of plastic fragments and pellets on the strandline: a snapshot of a Brazilian beach. Environmental Monitoring and Assessment, 168(1-4), 299-304.

Costa, M. F., Silva-Cavalcanti, J. S., Barbosa, C. C., Portugal, J. L. \& Barletta, M. (2011). Plastics buried in the inter-tidal plain of a tropical estuarine ecosystem. Journal of Coastal Research SI, 64, 339-343.

Cózar, A., Echevarría, F., González-Gordillo, J. I., Irigoien, X., Úbeda, B., Hernández-León, S., et al. (2014). Plastic debris in the open ocean. Proceedings of the National Academy of Sciences of the United States of America, 111(28), 10239-10244.

Dantas, D. V., Barletta, M., \& Da Costa, M. F. (2012). The seasonal and spatial patterns of ingestion of polyfilament nylon fragments by estuarine drums (Sciaenidae). Environmental Science and Pollution Research International, 19(2), 600-606.

Davison, P., \& Asch, R. (2011). Plastic ingestion by mesopelagic fishes in the North Pacific Subtropical Gyre. Marine Ecology Progress Series, 432, 173-180.

Day, R. H., \& Shaw, D. G. (1987). Patterns in the abundance of pelagic plastic and tar in the North Pacific Ocean, 1976-1985. Marine Pollution Bulletin, 18(6), 311-316.

Day, R. H., Shaw, D. G. \& Ignell, S. E. (1990). The quantitative distribution and characteristics of neuston plastic in the North Pacific Ocean, 1985-88. In R. S. Shomura \& M. L. Godfrey (Eds.) Proceedings of the Second International Conference on Marine Debris (pp. 2-7). Honolulu, Hawaii. U.S Dep. Commerce., NOAA Technical. Memorandum. NMFS, NOAATM-SWFSC-154, 2-7 April 1989.

Dekiff, J. H., Remy, D., Klasmeier, J., \& Fries, E. (2014). Occurrence and spatial distribution of microplastics in sediments from Norderney. Environmental Pollution, 186, 248-256.

de Lucia, G., Caliani, I., Marra, S., Camedda, A., Coppa, S., Alcaro, L., et al. (2014). Amount and distribution of neustonic micro-plastic off the Western Sardinian coast (Central-Western Mediterranean Sea). Marine Environmental Research, 100, 10-16.

De Witte, B., Devriese, L., Bekaert, K., Hoffman, S., Vandermeersch, G., Cooreman, K., et al. (2014). Quality assessment of the blue mussel (Mytilus edulis): Comparison between commercial and wild types. Marine Pollution Bulletin, 85(1), 146-155.

Derraik, J. G. B. (2002). The pollution of the marine environment by plastic debris: A review. Marine Pollution Bulletin, 44(9), 842-852.

Desforges, J. P. W., Galbraith, M., Dangerfield, N., \& Ross, P. S. (2014). Widespread distribution of microplastics in subsurface seawater in the NE Pacific Ocean. Marine Pollution Bulletin, 79(1-2), 94-99. 
Devriese, L., Vandendriessche, S., Theetaert, H., Vandermeersch, G., Hostens, K. \& Robbens, J. (2014). Occurrence of synthetic fibres in brown shrimp on the Belgian part of the North Sea. Platform presentation, International workshop on fate and impact of microplastics in marine ecosystems (MICRO2014). Plouzane (France), 13-15 January 2014.

Dos Santos, J., \& Jobling, M. (1992). A model to describe gastric evacuation in cod (Gadus morhua L.) fed natural prey. ICES Journal of Marine Science: Journal du Conseil, 49(2), $145-154$.

Doyle, M. J., Watson, W., Bowlin, N. M., \& Sheavly, S. B. (2011). Plastic particles in coastal pelagic ecosystems of the Northeast Pacific ocean. Marine Environmental Research, 71(1), 41-52.

Dubaish, F., \& Liebezeit, G. (2013). Suspended microplastics and black carbon particles in the Jade System, Southern North Sea. Water, Air, and Soil pollution, 224(2), 1-8.

Durrieu de Madron, X. D., Houpert, L., Puig, P., Sanchez-Vidal, A., Testor, P., Bosse, A., et al. (2013). Interaction of dense shelf water cascading and open-sea convection in the Northwestern Mediterranean during winter 2012. Geophysical Research Letters, 40(7), $1379-1385$.

Endo, S., Takizawa, R., Okuda, K., Takada, H., Chiba, K., Kanehiro, H., et al. (2005). Concentration of polychlorinated biphenyls (PCBs) in beached resin pellets: Variability among individual particles and regional differences. Marine Pollution Bulletin, 50(10), 1103-1114.

Endo, S., Yuyama, M., \& Takada, H. (2013). Desorption kinetics of hydrophobic organic contaminants from marine plastic pellets. Marine Pollution Bulletin, 74(1), 125-131.

Engler, R. E. (2012). The complex interaction between marine debris and toxic chemicals in the ocean. Environmental Science \& Technology, 46(22), 12302-12315.

Eriksen, M., Lebreton, L. C. M., Carson, H. S., Thiel, M., Moore, C. J., Borerro, J. C., et al. (2014). Plastic pollution in the world's oceans: More than 5 Trillion plastic pieces weighing over 250,000 tons afloat at sea. PLOS ONE, 9, e111913.

Eriksen, M., Maximenko, N., \& Thiel, M. (2013). Plastic pollution in the South Pacific subtropical gyre. Marine Pollution Bulletin, 68(1-2), 71-76.

Eriksson, C., \& Burton, H. (2003). Origins and biological accumulation of small plastic particles in fur seals from Macquarie Island. AMBIO: A Journal of the Human Environment, 32, 380-384.

Farrell, P., \& Nelson, K. (2013). Trophic level transfer of microplastic: Mytilus edulis (L.) to Carcinus maenas (L.). Environmental Pollution, 177, 1-3.

Fischer, V., Elsner, N. O., Brenke, N., Schwabe, E., \& Brandt, A. (2015). Plastic pollution of the Kuril-Kamchatka-trench area (NW Pacific). Deep-Sea Research II, 111, 399-405.

Foekema, E. M., De Gruijter, C., Mergia, M. T., van Franeker, J. A., Murk, T. J., \& Koelmans, A. A. (2013). Plastic in north sea fish. Environmental Science \& Technology, 47(15), 8818-8824.

Fossi, M. C., Casini, S., Caliani, I., Panti, C., Marsili, L., Viarengo, A., et al. (2012a). The role of large marine vertebrates in the assessment of the quality of pelagic marine ecosystems. Marine Environmental Research, 77, 156-158.

Fossi, M. C., Panti, C., Guerranti, C., Coppola, D., Giannetti, M., Marsili, L., et al. (2012b). Are baleen whales exposed to the threat of microplastics? A case study of the mediterranean fin whale (Balaenoptera physalus). Marine Pollution Bulletin, 64(11), 2374-2379.

Fossi, M. C., Coppola, D., Baini, M., Giannetti, M., Guerranti, C., Marsili, L., et al. (2014). Large filter feeding marine organisms as indicators of microplastic in the pelagic environment: The case studies of the Mediterranean basking shark (Cetorhinus maximus) and fin whale (Balaenoptera physalus). Marine Environmental Research, 100, 17-24.

Frias, J. P. G. L., Sobral, P., \& Ferreira, A. M. (2010). Organic pollutants in microplastics from two beaches of the Portuguese coast. Marine Pollution Bulletin, 60(11), 1988-1992.

Frias, J. P. G. L., Otero, V., \& Sobral, P. (2014). Evidence of microplastics in samples of zooplankton from Portuguese coastal waters. Marine Environmental Research, 95, 89-95.

Fries, E., Dekiff, J. H., Willmeyer, J., Nuelle, M. T., Ebert, M., \& Remy, D. (2013). Identification of polymer types and additives in marine microplastic particles using pyrolysis-GC/MS and scanning electron microscopy. Environmental Science: Processes \& Impacts, 15(10), $1949-1956$. 
Furness, R. W. (1985a). Plastic particle pollution: accumulation by Procellariiform seabirds at Scottish colonies. Marine Pollution Bulletin, 16(3), 103-106.

Furness, R. W. (1985b). Ingestion of plastic particles by seabirds at Gough Island, South Atlantic Ocean. Environmental Pollution Series A, Ecological and Biological, 38(3), 261-272.

Fry, D. M., Fefer, S. I., \& Sileo, L. (1987). Ingestion of plastic debris by Laysan albatrosses and wedge-tailed shearwaters in the Hawaiian Islands. Marine Pollution Bulletin, 18(6), 339-343.

Galgani, F., Claro, F., Depledge, M. \& Fossi, C. (2014). Monitoring the impact of litter in large vertebrates in the Mediterranean Sea within the European Marine Strategy Framework Directive (MSFD): Constraints, specificities and recommendations. Marine Environmental Research, 100, 3-9.

Galloway, T. S. (2015). Micro- and nano-plastics and human health. In M. Bergmann, L. Gutow, M. Klages (Eds.), Marine anthropogenic litter, (pp. 347-370). Springer, Berlin.

Gassel, M., Harwani, S., Park, J. S., \& Jahn, A. (2013). Detection of nonylphenol and persistent organic pollutants in fish from the North Pacific Central Gyre. Marine Pollution Bulletin, 73(1), 231-242.

GESAMP (2010). Proceedings of the GESAMP international workshop on plastic particles as a vector in transporting persistent, bio-accumulating and toxic substances in the oceans, 28-30th June 2010, UNESCO-IOC Paris. In T. Bowmer \& P. J. Kershaw (Eds.), GESAMP Reports and Studies, $68 \mathrm{pp}$.

Gilfillan, L. R., Ohman, M. D., Doyle, M. J., \& Watson, W. (2009). Occurrence of plastic microdebris in the Southern California Current system. California Cooperative Oceanic and Fisheries Investigations, 50, 123-133.

Goldstein, M. C., Rosenberg, M., \& Cheng, L. (2012). Increased oceanic microplastic debris enhances oviposition in an endemic pelagic insect. Biology Letters, 8(5), 817-820.

Goldstein, M. C. \& Goodwin, D. S. (2013). Gooseneck barnacles (Lepas spp.) ingest microplastic debris in the North Pacific Subtropical Gyre. PeerJ, 1(e841).

Goldstein, M. C., Titmus, A. J., \& Ford, M. (2013). Scales of spatial heterogeneity of plastic marine debris in the Northeast Pacific Ocean. PLoS ONE, 8(11), e80020. doi:10.1371/ journal.pone.0080020.

Graham, E. R., \& Thompson, J. T. (2009). Deposit- and suspension-feeding sea cucumbers (Echinodermata) ingest plastic fragments. Journal of Experimental Marine Biology and Ecology, 368(1), 22-29.

Gregory, M. R. (1978). Accumulation and distribution of virgin plastic granules on beaches. New Zealand Journal of Marine and Freshwater Research, 12, 399-414.

Gregory, M. R. (1983). Virgin plastic granules on some beaches of Eastern Canada and Bermuda. Marine Environmental Research, 10(2), 73-92.

Harper, P. C., \& Fowler, J. A. (1987). Plastic pellets in New Zealand storm-killed prions (Pachyptila spp.) 1958-1977. Notornis, 34(1), 65-70.

Hart, M. W. (1991). Particle capture and the method of suspension feeding by echinoderm larvae. Biology Bulletin, 180(1), 12-27.

Hays, H., \& Cormons, G. (1974). Plastic particles found in tern pellets, on coastal beaches and at factory sites. Marine Pollution Bulletin, 5(3), 44-46.

Heo, N. W., Hong, S. H., Han, G. M., Hong, S., Lee, J., Song, Y. K., et al. (2013). Distribution of small plastic debris in cross-section and high strandline on Heungnam beach, South Korea. Ocean Science Journal, 48(2), 225-233.

Hidalgo-Ruz, V., \& Thiel, M. (2013). Distribution and abundance of small plastic debris on beaches in the SE Pacific (Chile): A study supported by a citizen science project. Marine Environmental Research, 87-88, 12-18.

Hirai, H., Takada, H., Ogata, Y., Yamashita, R., Mizukawa, K., Saha, M., et al. (2011). Organic micropollutants in marine plastics debris from the open ocean and remote and urban beaches. Marine Pollution Bulletin, 62(8), 1683-1692.

Holmes, L. A., Turner, A., \& Thompson, R. C. (2012). Adsorption of trace metals to plastic resin pellets in the marine environment. Environmental Pollution, 160(1), 42-48. 
Ismail, A., Adilah, N. M. B., \& Nurulhudha, M. J. (2009). Plastic pellets along Kuala SelangorSepang coastline. Malaysian Applied Biology Journal, 38, 85-88.

Ivar Do Sul, J. A., Spengler, A. \& Costa, M. F. (2009). Here, there and everywhere. Small plastic fragments and pellets on beaches of Fernando de Noronha (Equatorial Western Atlantic). Marine Pollution Bulletin, 58(8), 1236-1238.I.

Ivar do Sul, J. A., Costa, M. F., Barletta, M. \& Cysneiros, F. J. A. (2013). Pelagic microplastics around an archipelago of the Equatorial Atlantic. Marine Pollution Bulletin, 75(1), 305-309.

Ivar do Sul, J. A. \& Costa, M. F. (2014). The present and future of microplastic pollution in the marine environment. Environmental Pollution, 185, 352-364.

Ivar do Sul, J. A., Costa, M. F. \& Fillmann, G. (2014). Microplastics in the pelagic environment around oceanic islands of the Western Tropical Atlantic Ocean. Water, Air \& Soil Pollution, $225(7), 1-13$.

Jambeck, J. R., Geyer, R., Wilcox, C., Siegler, T. R., Perryman, M., Andrady, A., et al. (2015). Plastic waste inputs from land into the ocean. Science, 347, 768-771.

Jayasiri, H. B., Purushothaman, C. S., \& Vennila, A. (2013). Quantitative analysis of plastic debris on recreational beaches in Mumbai, India. Marine Pollution Bulletin, 77(1), 107-112.

Kaberi, H., Tsangaris, C., Zeri, C., Mousdis, G., Papadopoulos, A., \& Streftaris, N. (2013). Microplastics along the shoreline of a Greek island (Kea island, Aegean Sea): Types and densities in relation to beach orientation, characteristics and proximity to sources. In Proceedings of the 4th International Conference on Environmental Management, Engineering, Planning and Economics (CEMEPE) and SECOTOX Conference. Mykonos island, Greece, June 24-28, ISBN:978-960-6865-68-8.

Kaiser, J. (2010). The dirt on ocean garbage patches. Science, 328(5985), 1506.

Kako, S. I., Isobe, A., Kataoka, T., \& Hinata, H. (2014). A decadal prediction of the quantity of plastic marine debris littered on beaches of the East Asian marginal seas. Marine Pollution Bulletin, 81(1), 174-184.

Kaposi, K. L., Mos, B., Kelaher, B., \& Dworjanyn, S. A. (2014). Ingestion of microplastic has limited impact on a marine larva. Environmental Science \& Technology, 48(3), 1638-1645.

Karapanagioti, H. K., \& Klontza, I. (2007). Investigating the properties of resin pellets found in the coastal areas of Lesvos Island. Global Nest. The International Journal, 9(1), 71-76.

Karapanagioti, H. K., Endo, S., Ogata, Y., \& Takada, H. (2011). Diffuse pollution by persistent organic pollutants as measured in plastic pellets sampled from various beaches in Greece. Marine Pollution Bulletin, 62(2), 312-317.

Karl, D. M. (1999). A sea of change: Biogeochemical variability in the North Pacific Subtropical Gyre. Ecosystems, 2, 181-214.

Kartar, S., Milne, R. A., \& Sainsbury, M. (1973). Polystyrene waste in the Severn Estuary. Marine Pollution Bulletin, 4(9), 144.

Kartar, S., Abou-Seedo, F., \& Sainsbury, M. (1976). Polystyrene Spherules in the Severn Estuary-A progress report. Marine Pollution Bulletin, 7(3), 52.

Khordagui, H. K., \& Abu-Hilal, A. H. (1994). Industrial plastic on the southern beaches of the Arabian Gulf and the western beaches of the Gulf of Oman. Environmental Pollution, 84(3), 325-327.

Kiessling, T., Gutow, L., \& Thiel, M. (2015). Marine litter as a habitat and dispersal vector. In M. Bergmann, L. Gutow, \& M. Klages (Eds.), Marine anthropogenic litter (pp. 141-181). Springer, Berlin.

Koelmans, A. A. (2015). Modeling the role of microplastics in bioaccumulation of organic chemicals to marine aquatic organisms. Critical review. In M. Bergmann, L. Gutow, M. Klages (Eds.), Marine anthropogenic litter (pp. 313-328). Springer, Berlin.

Koelmans, A. A., Besseling, E., \& Shim, W. J. (2015) Nanoplastics in the aquatic environment. In M. Bergmann, L. Gutow, \& M. Klages (Eds.), Marine anthropogenic litter (pp. 329344). Springer, Berlin.

Köhler, A. (2010). Cellular fate of organic compounds in marine invertebrates. Comparative Biochemistry and Physiology-Part A: Molecular \& Integrative Physiology, 157(Supplement), 8-11. 
Kühn, S., Bravo Rebolledo, E. L., \& van Franeker, J. A. (2015). Deleterious effects of litter on marine life. In M. Bergmann, L. Gutow, \& M. Klages (Eds.), Marine anthropogenic litter (pp. 75-116). Springer, Berlin.

Kühn, S., \& van Franeker, J. A. (2012). Plastic ingestion by the northern fulmar (Fulmarus glacialis) in Iceland. Marine Pollution Bulletin, 64(6), 1252-1254.

Kukulka, T., Proskurowski, G., Morét-Ferguson, S., Meyer, D. W., \& Law, K. L. (2012). The effect of wind mixing on the vertical distribution of buoyant plastic debris. Geophysical Research Letters, 39(7), L07601.

Kripa, V., Nair, P. G., Dhanya, A. M., Pravitha, V. P., Abhilash, K. S., Mohammed, A. A., et al. (2014). Microplastics in the gut of anchovies caught from the mud bank area of Alappuzha, Kerala. Marine Fisheries Information Service; Technical and Extension Series, 219, $27-28$.

Kuriyama, Y., Konishi, K., Kanehiro, H., Otake, C., Kaminuma, T., Mato, Y., et al. (2002). Plastic pellets in the marine environment of Tokyo Bay and Sagami Bay. Bulletin of the Japanese Society of Scientific Fisheries, 68(2), 164-171.

Kusui, T., \& Noda, M. (2003). International survey on the distribution of stranded and buried litter on beaches along the Sea of Japan. Marine Pollution Bulletin, 47(1), 175-179.

Lattin, G. L., Moore, C. J., Zellers, A. F., Moore, S. L., \& Weisberg, S. B. (2004). A comparison of neustonic plastic and zooplankton at different depths near the southern California shore. Marine Pollution Bulletin, 49(4), 291-294.

Law, K. L., Morét-Ferguson, S., Maximenko, N. A., Proskurowski, G., Peacock, E. E., Hafner, J., et al. (2010). Plastic accumulation in the North Atlantic subtropical gyre. Science, 329(5996), 1185-1188.

Law, K. L., Morét-Ferguson, S., Goodwin, D. S., Zettler, E. R., DeForce, E., Kukulka, T., et al. (2014). Distribution of surface plastic debris in the eastern Pacific Ocean from an 11-year dataset. Environmental Science \& Technology, 48(9), 44732-44738.

Lee, K.-W., Shim, W. J., Kwon, O. Y., \& Kang, J.-H. (2013). Size-dependent effects of micro polystyrene particles in the marine copepod Tigriopus japonicus. Environmental Science \& Technology, 47(19), 11278-11283.

Liebezeit, G., \& Dubaish, F. (2012). Microplastics in beaches of the East Frisian Islands Spiekeroog and Kachelotplate. Bulletin of Environmental Contamination \& Toxicology, 89(1), 213-217.

Lima, A. R. A., Costa, M. F., \& Barletta, M. (2014). Distribution patterns of microplastics within the plankton of a tropical estuary. Environmental Research, 132, 146-155.

Lindborg, V. A., Ledbetter, J. F., Walat, J. M., \& Moffett, C. (2012). Plastic consumption and diet of Glaucous-winged gulls (Larus glaucescens). Marine Pollution Bulletin, 64(11), 2351-2356.

Lobelle, D., \& Cunliffe, M. (2011). Early microbial biofilm formation on marine plastic debris. Marine Pollution Bulletin, 62(1), 197-200.

Löder, M. G. J., \& Gerdts, G. (2015). Methodology used for the detection and identification of microplastics-A critical appraisal. In M. Bergmann, L. Gutow, \& M. Klages (Eds.), Marine anthropogenic litter (pp. 201-227). Springer, Berlin.

Long, M., Hégaret, H., Lambert, C., Le Goic, N., Huvetm, A., Robbens, J., et al. (2014). Can phytoplankton species impact microplastic behaviour within water column? Platform presentation, International workshop on fate and impact of microplastics in marine ecosystems (MICRO2014) 13-15 January 2014. Plouzane (France).

Lusher, A. L., Burke, A., O'Connor, I., \& Officer, R. (2014). Microplastic pollution in the Northeast Atlantic Ocean: validated and opportunistic sampling. Marine Pollution Bulletin, 88(1-2), 325-333.

Lusher, A. L., McHugh, M., \& Thompson, R. C. (2013). Occurrence of microplastics in the gastrointestinal tract of pelagic and demersal fish from the English Channel. Marine Pollution Bulletin, 67(1-2), 94-99.

Magnusson, K. (2014). Microlitter and other microscopic anthropogenic particles in the sea area off Rauma and Turku, Finland. Swedish Environmental Institute Report U4645, 17 pp. 
Majer, A. P., Vedolin, M. C., \& Turra, A. (2012). Plastic pellets as oviposition site and means of dispersal for the ocean-skater insect Halobates. Marine Pollution Bulletin, 64(6), 1143-1147.

Mallory, M. L., Roberston, G. J., \& Moenting, A. (2006). Marine plastic debris in northern fulmars from Davis Strait, Nunavut, Canada. Marine Pollution Bulletin, 52(7), 813-815.

Martins, J., \& Sobral, P. (2011). Plastic marine debris on the Portuguese coastline: A matter of size? Marine Pollution Bulletin, 62(12), 2649-2653.

Mathalon, A., \& Hill, P. (2014). Microplastic fibers in the intertidal ecosystem surrounding Halifax Harbor, Nova Scotia. Marine Pollution Bulletin, 81(1), 69-79.

Mato, Y., Isobe, T., Takada, H., Kanehiro, H., Ohtake, C., \& Kaminuma, T. (2001). Plastic resin pellets as a transport medium for toxic chemicals in the marine environment. Environmental Science \& Technology, 35(2), 318-324.

Mazurais, D., Huvet, A., Madec, L., Quazuguel, P., Severe, A., Desbruyeres, E., et al. (2014). Impact of polyethylene microbeads ingestion on seabass larvae development Platform presentation, International workshop on fate and impact of microplastics in marine ecosystems (MICRO2014), 13-15 January 2014. Plouzane (France).

McDermid, K. J., \& McMullen, T. L. (2004). Quantitative analysis of small-plastic debris on beaches in the Hawaiian Archipelago. Marine Pollution Bulletin, 48(7), 790-794.

Mohamed Nor, H., \& Obbard, J. P. (2014). Microplastics in Singapore's coastal mangrove ecosystems. Marine Pollution Bulletin, 79, 278-283.

Moore, C. J. (2008). Synthetic polymers in the marine environment: A rapidly increasing, longterm threat. Environmental Research, 108(2), 131-139.

Moore, C. J., Moore, S. L., Leecaster, M. K., \& Weisberg, S. B. (2001). A comparison of plastic and plankton in the north Pacific central gyre. Marine Pollution Bulletin, 42(12), 1297-1300.

Moore, C. J., Moore, S. L., Weisberg, S. B., Lattin, G. L., \& Zellers, A. F. (2002). A comparison of neustonic plastic and zooplankton abundance in southern California's coastal waters. Marine Pollution Bulletin, 44(10), 1035-1038.

Morét-Ferguson, S., Law, K. L., Proskurowski, G., Murphy, E. K., Peacock, E. E., \& Reddy, C. M. (2010). The size, mass, and composition of plastic debris in the western North Atlantic Ocean. Marine Pollution Bulletin, 60(10), 1873-1878.

Morris, A., \& Hamilton, E. (1974). Polystyrene spherules in the Bristol Channel. Marine Pollution Bulletin, 5(2), 26-27.

Morris, R. J. (1980). Plastic debris in the surface waters of the South Atlantic. Marine Pollution Bulletin, 11(6), 164-166.

Morritt, D., Stefanoudis, P. V., Pearce, D., Crimmen, O. A., \& Clark, P. F. (2014). Plastic in the Thames: A river runs through it. Marine Pollution Bulletin, 78(1), 196-200.

Moser, M. L., \& Lee, D. S. (1992). A fourteen-year survey of plastic ingestion by western North Atlantic seabirds. Colonial Waterbirds, 15(1), 83-94.

Mrosovsky, N., Bass, A., Corliss, L. A., Richardson, J. I., \& Richardson, T. H. (1992). Pivotal and beach temperatures for hawksbill turtles nesting in Antigua. Canadian Journal of Zoology, 70, 1920-1925.

Murray, F., \& Cowie, P. R. (2011). Plastic contamination in the decapod crustacean Nephrops norvegicus (Linnaeus, 1758). Marine Pollution Bulletin, 62(6), 1207-1217.

Nemoto, T. (1970). Feeding pattern of baleen whales in the ocean. In J. H. Steele (Ed.), Marine food chains (pp. 241-252). Edinburgh: Oliver and Boyd.

Newman, S., Watkins, E., Farmer, A., Ten Brink, P., \& Schweitzer, J.-P. (2015). The economics of marine litter. In M. Bergmann, L. Gutow, \& M. Klages (Eds.), Marine anthropogenic litter (pp. 371-398). Springer, Berlin.

Ng, K. L., \& Obbard, J. P. (2006). Prevalence of microplastics in Singapore's coastal marine environment. Marine Pollution Bulletin, 52(7), 761-767.

Norén, F. (2007). Small Plastic Particles in Coastal Swedish Waters. N-Research report, commissioned by KIMO, Sweden. 11 pp. 
Norén, F., \& Naustvoll, L.-J. (2011). Survey of microscopic anthropogenic particles in Skagerrak (p. 21). Flødevigen, Norway: Institute of Marine Research.

Obbard, R. W., Sadri, S., Wong, Y. Q., Khitun, A. A., Baker, I., \& Thompson, R. C. (2014). Global warming releases microplastic legacy frozen in Arctic Sea ice. Earth's Future, 2(6), 315-320.

Ogata, Y., Takada, H., Mizukawa, K., Hirai, H., Iwasa, S., Endo, S., et al. (2009). International Pellet Watch: global monitoring of persistent organic pollutants (POPs) in coastal waters. 1. Initial phase data on PCBs, DDTs, and HCHs. Marine Pollution Bulletin, 58(10), 1437-1446.

Ogi, H. (1990). Ingestion of plastic particles by sooty and short-tailed shearwaters in the North Pacific. In Proceedings of the Second International Conference on Marine Debris (pp. 635652). Honolulu, Hawaii, 2-7 April 1989.

Ohlendorf, H. M., Risebrough, R. W., \& Vermeer, K. (1978). Exposure of marine birds to environmental pollutants [Oil, organochlorines, heavy metals, toxicity]. Wildlife Research Report (USA). no. 9.

Oliveira, M., Ribeiro, A., Hylland, K., \& Guilhermino, L. (2013). Single and combined effects of microplastics and pyrene on juveniles $(0+$ group $)$ of the common goby Pomatoschistus microps (Teleostei, Gobiidae). Ecological Indicators, 34, 641-647.

Pauly, D., Trites, A. W., Capuli, E., \& Christensen, V. (1998). Diet composition and trophic levels of marine mammals. ICES Journal of Marine Science, 55(3), 467-481.

Possatto, F. E., Barletta, M., Costa, M. F., Ivar do Sul, J. A. \& Dantas, D. V. (2011). Plastic debris ingestion by marine catfish: An unexpected fisheries impact. Marine Pollution Bulletin, 62(5), 1098-1102.

Pott, A. (2014). A new method for the detection of microplastics in the North Sea brown shrimp (Crangon crangon) by Fourier Transform Infrared Spectroscopy (FTIR). M.Sc. thesis, RWTH Aachen University/Alfred Wegener Institute Helmholtz Centre for Polar and Marine Research, $61 \mathrm{pp}$.

Provencher, J. F., Gaston, A. J., \& Mallory, M. L. (2009). Evidence for increased ingestion of plastics by northern fulmars (Fulmarus glacialis) in the Canadian Arctic. Marine Pollution Bulletin, 58(7), 1092-1095.

Provencher, J. F., Gaston, A. J., Mallory, M. L., O’hara, P. D., \& Gilchrist, H. G. (2010). Ingested plastic in a diving seabird, the thick-billed murre (Uria lomvia), in the eastern Canadian Arctic. Marine Pollution Bulletin, 60(9), 1406-1411.

Ramos, J. A. A., Barletta, M., \& Costa, Monica F. (2012). Ingestion of nylon threads by Gerreidae while using a tropical estuary as foraging grounds. Aquatic Biology, 17, 29-34.

Reddy, M. S., Basha, S., Adimurthy, S., \& Ramachandraiah, G. (2006). Description of the small plastics fragments in marine sediments along the Alang-Sosiya ship-breaking yard, India. Estuarine, Coastal and Shelf Science, 68(3), 656-660.

Reid, S. (1981). Wreck of kerguelen and blue petrels. Notornis, 28, 239-240.

Reisser, J., Shaw, J., Wilcox, C., Hardesty, B. D., Proietti, M., Thums, M., et al. (2013). Marine plastic pollution in waters around Australia: Characteristics, concentrations, and pathways. PLOS ONE, 8(11), e80466.

Rios, L. M., Moore, C., \& Jones, P. R. (2007). Persistent organic pollutants carried by synthetic polymers in the ocean environment. Marine Pollution Bulletin, 54(8), 1230-1237.

Robards, M. D., Piatt, J. F., \& Wohl, K. D. (1995). Increasing frequency of plastic particles ingested by seabirds in the subarctic North Pacific. Marine Pollution Bulletin, 30(2), 151-157.

Rochman, C. M. (2015). The complex mixture, fate and toxicity of chemicals associated with plastic debris in the marine environment. In M. Bergmann, L. Gutow, \& M. Klages (Eds.), Marine anthropogenic litter (pp. 117-140). Springer, Berlin.

Rochman, C. M., Hoh, E., Kurobe, T., \& Teh, S. J. (2013). Ingested plastic transfers hazardous chemicals to fish and induces hepatic stress. Scientific Reports, 3(3263).

Rochman, C. M., Kurobe, T., Flores, I., \& Teh, S. J. (2014). Early warning signs of endocrine disruption from the ingestion of plastic debris in the adult Japanese medaka (Oryzias latipes). Science of the Total Environment, 493, 656-661. 
Rodríguez, A., Rodríguez, B., \& Nazaret Carrasco, M. (2012). High prevalence of parental delivery of plastic debris in Cory's shearwaters (Calonectris diomedea). Marine Pollution Bulletin, 64(10), 2219-2223.

Rossi, G., Barnoud, J., \& Monticelli, L. (2013). Polystyrene nanoparticles perturb lipid membranes. The Journal of Physical Chemistry Letters, 5(1), 241-246.

Rothstein, S. I. (1973). Plastic particle pollution of the surface of the Atlantic Ocean: Evidence from a seabird. Condor, 75(344), 5.

Ryan, P. G. (1987). The incidence and characteristics of plastic particles ingested by seabirds. Marine Environmental Research, 23(3), 175-206.

Ryan, P. G. (1988). The characteristics and distribution of plastic particles at the sea-surface off the southwestern Cape Province, South Africa. Marine Environmental Research, 25(4), 249-273.

Ryan, P. G. (2008). Seabirds indicate changes in the composition of plastic litter in the Atlantic and south-western Indian Oceans. Marine Pollution Bulletin, 56(8), 1406-1409.

Ryan, P. G., Moore, C. J., van Franeker, J. A., \& Moloney, C. L. (2009). Monitoring the abundance of plastic debris in the marine environment. Philosophical Transactions of the Royal Society of London B, 364(1526), 1999-2012.

Sadri, S. S., \& Thompson, R. C. (2014). On the quantity and composition of floating plastic debris entering and leaving the Tamar Estuary, Southwest England. Marine Pollution Bulletin, 81(1), 55-60.

Schuyler, Q., Hardesty, B. D., Wilcox, C., \& Townsend, K. (2014). Global analysis of anthropogenic debris ingestion by sea turtles. Conservation Biology, 28(1), 129-139.

Setälä, O., Fleming-Lehtinen, V., \& Lehtiniemi, M. (2014). Ingestion and transfer of microplastics in the planktonic food web. Environmental Pollution, 185, 77-83.

Shiber, J. G. (1979). Plastic pellets on the coast of Lebanon. Marine Pollution Bulletin, 10(1), 28-30.

Shiber, J. G. (1982). Plastic pellets on Spain's 'Costa del Sol' beaches. Marine Pollution Bulletin, 13(12), 409-412.

Shiber, J. G. (1987). Plastic pellets and tar on Spain's Mediterranean beaches. Marine Pollution Bulletin, 18(2), 84-88.

Sileo, L., Sievert, P. R., Samuel, M. D., \& Fefer, S. I. (1990). Prevalence and characteristics of plastic ingested by Hawaiian seabirds. In Proceedings of the Second International Conference on Marine Debris (pp. 2-7). Honolulu, Hawaii, 2-7 April 1989.

Slip, D. J., Green, K., \& Woehler, E. J. (1990). Ingestion of anthropogenic articles by seabirds at Macquarie Island. Marine Ornithology, 18(1), 74-77.

Song, Y. K., Hong, S. H., Kang, J. H., Kwon, O. Y., Jang, M., Han, G. M., et al. (2014). Large accumulation of micro-sized synthetic polymer particles in the sea surface microlayer. Environmental Science \& Technology, 48(16), 9014-9021.

Spear, L. B., Ainley, D. G., \& Ribic, C. A. (1995). Incidence of plastic in seabirds from the tropical pacific, 1984-1991: Relation with distribution of species, sex, age, season, year and body weight. Marine Environmental Research, 40(2), 123-146.

Sussarellu, R., Soudant, P., Lambert, C., Fabioux, C., Corporeau, C., Laot, C., et al. (2014). Microplastics: effects on oyster physiology and reproduction. Platform presentation, International workshop on fate and impact of microplastics in marine ecosystems (MICRO2014), 13-15 January 2014. Plouzane (France).

Sutherland, W. J., Clout, M., Côté, I. M., Daszak, P., Depledge, M. H., Fellman, 1., et al. (2010). A horizon scan of global conservation issues for 2010. Trends in Ecology \& Evolution, 25, 1-7.

Takada, H. (2006). Call for pellets! International pellet watch global monitoring of POPs using beached plastic resin pellets. Marine Pollution Bulletin, 52(12), 1547-1548.

Tanaka, K., Takada, H., Yamashita, R., Mizukawa, K., Fukuwaka, M.-A., \& Watanuki, Y. (2013). Accumulation of plastic-derived chemicals in tissues of seabirds ingesting marine plastics. Marine Pollution Bulletin, 69(1-2), 219-222.

Teuten, E. L., Rowland, S. J., Galloway, T. S., \& Thompson, R. C. (2007). Potential for plastics to transport hydrophobic contaminants. Environmental Science \& Technology, 41(22), 7759-7764. 
Teuten, E. L., Saquing, J. M., Knappe, D. R. U., Barlaz, M. A., Jonsson, S., Björn, A., et al. (2009). Transport and release of chemicals from plastics to the environment and to wildlife. Philological Transactions of the Royal Society London B, 364(1526), 2027-2045.

Thompson, R. C. (2006). Plastic debris in the marine environment: Consequences and solutions. In J. C. Krause, H. von Nordheim, \& S. Bräger (Eds.), Marine Nature Conservation in Europe (pp. 107-115). Stralsund, Germany: Federal Agency for Nature Conservation.

Thompson, R. C., Olsen, Y., Mitchell, R. P., Davis, A., Rowland, S. J., John, A. W. G., et al. (2004). Lost at sea: where is all the plastic? Science, 304(5672), 838.

Thompson, R. C., Moore, C. J., Saal, F. S., \& Swan, S. H. (2009). Plastics, the environment and human health: current consensus and future trends. Philosophical Transactions of the Royal Society of London B, 364, 2153-2166.

Tourinho, P. S., Ivar do Sul, J. A. \& Fillmann, G. (2010). Is marine debris ingestion still a problem for the coastal marine biota of southern Brazil? Marine Pollution Bulletin, 60(3), 396-401.

Turner, A., \& Holmes, L. (2011). Occurrence, distribution and characteristics of beached plastic production pellets on the island of Malta (central Mediterranean). Marine Pollution Bulletin, 62(2), 377-381.

Turra, A., Manzano, A. B., Dias, R. J. S., Mahiques, M. M., Barbosa, L., Balthazar-Silva, D., \& Moreira, F. T. (2014). Three-dimensional distribution of plastic pellets in sandy beaches: shifting paradigms. Scientific Reports, 4(4435).

Ugolini, A., Ungherese, G., Ciofini, M., Lapucci, A., \& Camaiti, M. (2013). Microplastic debris in sandhoppers. Estuarine, Coastal and Shelf Science, 129, 19-22.

Van, A., Rochman, C. M., Flores, E. M., Hill, K. L., Varges, E., Vargas, S. A., et al. (2012). Persistent organic pollutants in plastic marine debris found on beaches in San Diego, California. Chemosphere, 86(3), 258-263.

van Cauwenberghe, L., Claessens, M., Vandegehuchte, M. B., Mees, J., \& Janssen, C. R. (2013a). Assessment of marine debris on the Belgian continental shelf. Marine Pollution Bulletin, 73(1), 161-169.

van Cauwenberghe, L., Vanreusel, A., Mees, J., \& Janssen, C. R. (2013b). Microplastic pollution in deep-sea sediments. Environmental Pollution, 182, 495-499.

van Cauwenberghe, L., \& Janssen, C. R. (2014). Microplastics in bivalves cultured for human consumption. Environmental Pollution, 193, 65-70.

van Dolah, R. F., Burrell, V. G., \& West, S. B. (1980). The distribution of pelagic tars and plastics in the south Atlantic bight. Marine Pollution Bulletin, 11(12), 352-356.

van Franeker, J. A. (1985). Plastic ingestion in the North Atlantic fulmar. Marine Pollution Bulletin, 16(9), 367-369.

van Franeker, J. A., \& Bell, P. J. (1988). Plastic ingestion by petrels breeding in Antarctica. Marine Pollution Bulletin, 19(12), 672-674.

van Franeker, J. A., Blaize, C., Danielsen, J., Fairclough, K., Gollan, J., Guse, N., et al. (2011). Monitoring plastic ingestion by the northern fulmar Fulmarus glacialis in the North Sea. Environmental Pollution, 159(10), 2609-2615.

van Sebille, E., England, M. H., \& Froyland, G. (2012). Origin, dynamics and evolution of ocean garbage patches from observed surface drifters. Environmental Research Letters, 7, 044040.

Vianello, A., Boldrin, A., Guerriero, P., Moschino, V., Rella, R., Sturaro, A., et al. (2013). Microplastic particles in sediments of Lagoon of Venice, Italy: First observations on occurrence, spatial patterns and identification. Estuarine, Coastal and Shelf Science, 130, 54-61.

Viehman, S., Vander, J. L., Schellinger, J., \& North, C. (2011). Characterization of marine debris in North Carolina salt marshes. Marine Pollution Bulletin, 62(12), 2771-2779.

Vlietstra, L. S., \& Parga, J. A. (2002). Long-term changes in the type, but not amount, of ingested plastic particles in short-tailed shearwaters in the Southeastern Bering Sea. Marine Pollution Bulletin, 44(9), 945-955.

von Moos, N., Burkhardt-Holm, P., \& Köhler, A. (2012). Uptake and effects of microplastics on cells and tissue of the blue mussel Mytilus edulis L. after an experimental exposure. Environmental Science \& Technology, 46(20), 11327-11335. 
Ward, J. E., \& Targett, N. M. (1989). Influence of marine microalgal metabolites on the feeding behavior of the blue mussel Mytilus edulis. Marine Biology, 101, 313-321.

Ward, J. E., Levinton, J. S., \& Shumway, S. E. (2003). Influence of diet on pre-ingestive particle processing in bivalves: I: Transport velocities on the ctenidium. Journal of Experimental Marine Biology and Ecology, 293(2), 129-149.

Ward, J. E., \& Kach, D. J. (2009). Marine aggregates facilitate ingestion of nanoparticles by suspension-feeding bivalves. Marine Environmental Research, 68(3), 137-142.

Watts, A., Lewis, C., Goodhead, R. M., Beckett, D. J., Moger, J., Tyler, C., et al. (2014). Uptake and retention of microplastics by the shore crab Carcinus maenas. Environmental Science \& Technology, 48(15), 8823-8830.

Wegner, A., Besseling, E., Foekema, E. M., Kamermans, P., \& Koelmans, A. A. (2012). Effects of nanopolystyrene on the feeding behaviour of the blue mussel (Mytilus edulis L.). Environmental Toxicology and Chemistry, 31, 2490-2497.

Wilber, R. J. (1987). Plastic in the North Atlantic. Oceanus, 30(3), 61-68.

Wilson, D. S. (1973). Food size selection among copepods. Ecology, 54(4), 909-914.

Woodall, L. C., Sanchez-Vidal, A., Canals, M., Paterson, G. L. J., Coppock, R., Sleight, V., et al. (2014). The deep sea is a major sink for microplastic debris. Royal Society Open Science, 1, 140317.

Wright, S. L., Thompson, R. C., \& Galloway, T. S. (2013a). The physical impacts of microplastics on marine organisms: A review. Environmental Pollution, 178, 483-492.

Wright, S. L., Rowe, D., Thompson, R. C., \& Galloway, T. S. (2013b). Microplastic ingestion decreases energy reserves in marine worms. Current Biology, 23(23), R1031-R1033.

Yamashita, R., \& Tanimura, A. (2007). Floating plastic in the Kuroshio Current area, western North Pacific Ocean. Marine Pollution Bulletin, 54(4), 485-488.

Yamashita, R., Takada, H., Fukuwaka, M.-A., \& Watanuki, Y. (2011). Physical and chemical effects of ingested plastic debris on short-tailed shearwaters, Puffinus tenuirostris, in the North Pacific Ocean. Marine Pollution Bulletin, 62, 2845-2849.

Yntema, C., \& Mrosovsky, N. (1982). Critical periods and pivotal temperatures for sexual differentiation in loggerhead sea turtles. Canadian Journal of Zoology, 60, 1012-1016.

Zarfl, C., \& Matthies, M. (2010). Are marine plastic particles transport vectors for organic pollutants to the Arctic? Marine Pollution Bulletin, 60(10), 1810-1814.

Zarfl, C., Fleet, D., Fries, E., Galgani, F., Gerdts, G., Hanke, G., et al. (2011). Microplastics in oceans. Marine Pollution Bulletin, 62, 1589-1591. 